
The Bancroft Sibrary

University of Califormia - Berkeley 

Digitized by the Internet Archive in 2007 with funding from Microsoft Corporation 
THE LOG OF A TIMBER CRUISER 




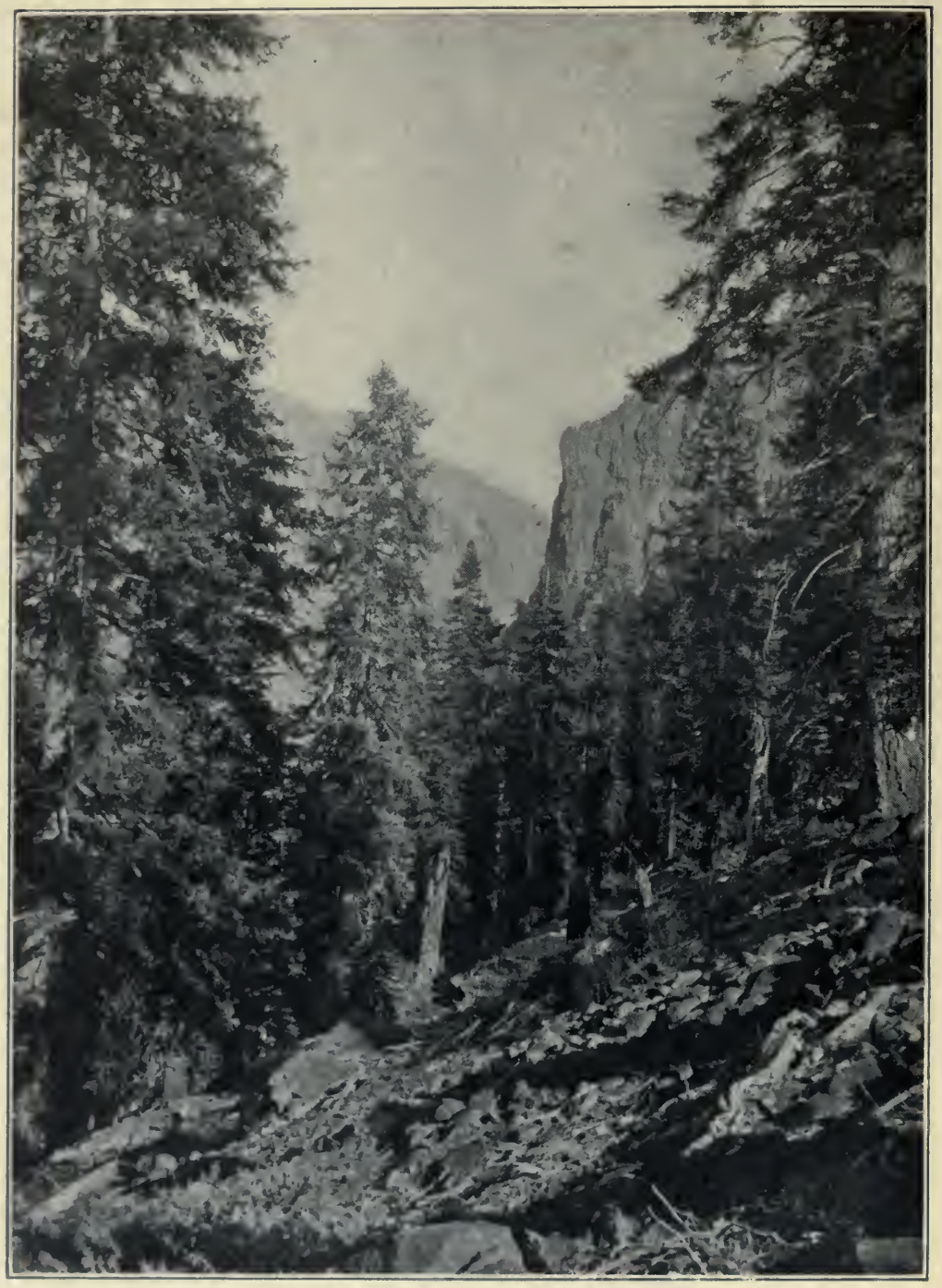

THE CLIFFS ON MORGAN CREEK 


\title{
THE LOG OF A TIMBER CRUISER
}

\author{
BY \\ WILLIAM PINKNEY LAWSON
}

\author{
ILLUSTRATED
}

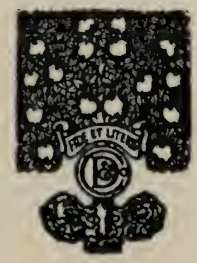

NEW YORK

DUFFIELD \& COMPANY

1915 
Copyright, 1915

BY DUFFIELD \& COMPANY 


\section{F797 \\ .12 \\ $\angle 38$}

To

PAUL P. PITCHLYNN

A GOOD BOSS AND A REGULAR FELLOW. 


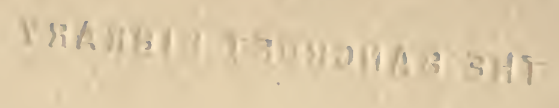




\section{FOREWORD}

Public knowledge of the reasons for the existence of the United States Forest Service is fairly widespread and accurate. Conservation-the intelligent use and development of the resources of our National Forests, has worked its way into the list of the Nation's permanent policies. But while most people are agreed as to the desirability of the work the Forest Service is doing and know in a general way what that work is, there exists a surprising lack of information as to the actual life and day-to-day duties of Service field men: Supervisors and Forest Assistants, Rangers and Guards.

"The Log of a Timber Cruiser" is in part an attempt to furnish such information-at least in one phase of Forest Service activity-by detailing the incidents of a six months' field assignment in the mountains of southern New Mexico. If, in addition, the reading of this account provides half the entertainment which the recording of the events as they occurred brought, I shall feel very much more than pleased.

Grateful acknowledgment is due Mr. Gifford Pinchot, the former Forester; Mr. Herbert A. Smith, Editor of the Forest Service; Mr. Bristow Adams, 


\section{FOREWORD}

of the Washington Office; Mr. Arthur C. Ringland; District Forester of the Southwest; and Mr. Don P. Johnson, Supervisor of the Gila National Forest, for their careful examination of the manuscript and for their many suggestions to which in no small measure whatever of merit the story possesses must be attributed.

Readers of the manuscript have suggested that a number of terms used, while common enough in the locality where the story is set or in Forest Service circles, may not be familiar to the general reader. To obviate this difficulty without stopping in every case during the action of the log to explain such expressions a brief glossary is appended which defines those words and phrases that seem most to want defining. I think that's all-except the story.

W. P. L.

New York City,

1914. 


\section{CONTENTS}

CHAPTER

PAGE

I The Reconnatsance Party . . . . . 1

II Getting Started • • • •

III The First DaY's Work . . . . . . 15

IV: SAWYeR's PeAK • • • • • • • • . 27

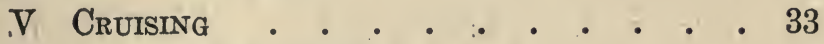

VI Moak's Adventure • • • • • • . 43

VII Horace has an Adventure • . . . 48

VIII AROUNd THE FIRE . . . . . . . . 54

IX EWING's Story . . . . . . . . 58

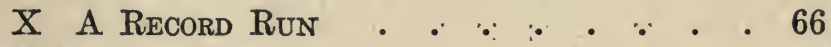

XI РновУ-CATS . .

XII Rounding the South ENd . $\because \quad \because \cdot \quad \because \quad 78$

XIII FIRE • • • • • • • • •

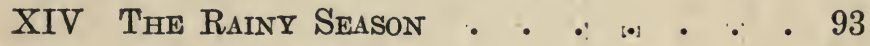

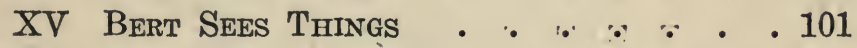

XVI Horace Takes a Stand $\bullet \cdot$. $: \bullet \quad \bullet \quad \cdot \quad \cdot 107$

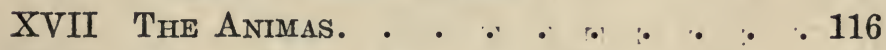

XVIII ,WoRKING THE ANIMAS $\because \quad . \cdot \quad . \quad \ddots \quad \ddots \quad .123$

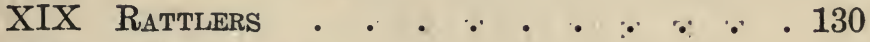

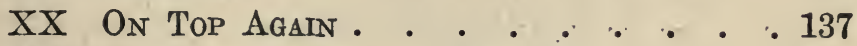

XXI The End of Ewing's Stort • . • . 144

XXII Old MAN Reed . • . • • • • • 150

XXIII Horace "CoMes Back" . @ $\because$. . . 156

XXIV, ON Diamond Creek . . $. \quad . \quad . \quad . \quad 164$ 


\section{CONTENTS}

CHAPTER

XXV LOST MAN's PARK . . . . . . . . 170

XXVI At the Diamond Bar . • . . . 176

XXVII HANK HоTCHKISS . . . . . . . 184

XXVIII The Last CaMp . . . . . . . 190

XXIX FINIS • . . . . . . . . . . 197

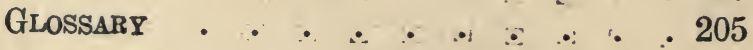




\section{LIST OF ILLUSTRATIONS}

The Cliffs on Morgan Creek . . . Frontispiece

The Cruisers $\left\{\begin{array}{l}\text { The Author } \\ \text { Bob Moak, the Veteran } \\ \text { Frazer, the Chief . . . . . . . . } 4\end{array}\right.$

The Cruiser Climbs High Peaks . . . . . . 10

Or Descends Into Yawning Canyons . . . . . 10

What the cruiser faces when setting out on a run . 18

This rugged region in the Black Range though bare of trees on top, was cruised to catch timber in the can-

yons and for map work . . . . . . . 18

Sample Plot Work . . . . . . . . . . 22

Easy Going for the Baseline Crew . . . . . . 22

At Work in the Field $\left\{\begin{array}{l}\text { Brown Setting a Cruiser's Sta- } \\ \text { tion } \\ \text { Conway and Stadia } \\ \text { Frazer Cruising . . . . . } \quad 24\end{array}\right.$

The Cruiser at Work $\left\{\begin{array}{l}\text { In Dense Cover } \\ \text { "Shall I Offset?" } \\ \text { Scaling Cliffs . . . . . . } 30\end{array}\right.$

Lunch Time . . . . . . . . . . . . 38

A Typical Rock Slide . . . . . . . . . . 46

What the Cruiser Dreads . . . . . . . 50

The "Woodland Type" of Timber . . . . . 60

On the Slope of the Main Ridge . . . . . 68

Perils of the Way $\left\{\begin{array}{l}\text { A Trail Through the Cliffs } \\ \text { The Jumping Off Place . . . } 74\end{array}\right.$

In moving from Donahue's Canyon we drove the burros along an almost invisible trail ...... .78 


\section{LIST OF ILLUSTRATIONS}

FACING PAGE

A halt for repairs. One of the packs slipped here and held up the whole procession . . . . . 78 Fire guard Reid on his look-out tower on Hillsboro Peak . . . . . . . . . . . 82 "When we arrived the fire was climbing to the top" 82 The approach of the fire . . . . . . . . . $\quad .86$ Fire in the brush . . . . . . . . . 86 "When the fire at length rose above the ridge, we were ready" . . . . . . . . . . 90 A Contrast in Canyons $\left\{\begin{array}{l}\text { Turkey Creek Canyon } \\ \text { A "Box" Canyon . . . . } 98\end{array}\right.$ Lumbering at $\mathrm{O}^{\prime}$ Brien's . . . . . . . . . 104 McKnight Canyon . . . . . . . . . . . 110 Over the McKnight-Animas Divide . . . . . 118 Whitey in deep trouble . . . . . . . 118 In the Animas country . . . . . . . . . 124 Black River . . . . . . . . . . . . 134 Evening on the range . . . . . . . . . 142 The northern limit of our work . . . . . . 150 "Old Man Reed's Place" . . . . . . . . 154 Panorama of range near the head of Diamond Creek . 158 At the source of Black River, where the Continental

Divide crosses . . . . . . . . . . 158 Moving-day . . . . . . . . . . . . 164 First camp on Diamond Creek . . . . . . 164 The Diamond Bar Range . . . . . . . . . 172 Preparing for the party . . . . . . . . 180 Washing day . . . . . . . . . 180 The last move . . . . . . . View at evening from the last camp in the Black Range 200 Typical cruising country in the higher levels . . 200 


\section{THE LOG OF A TIMBER CRUISER}





\section{THE LOG OF A TIMBER CRUISER}

\section{CHAPTER I \\ THE RECONNAISSANCE PARTY}

I was under appointment as Forest Guard on the Gila National Forest when the opportunity to take up reconnaissance work came. The Supervisor's letter was brief. It ran as follows:

"We can use another man on the Gila Cruising party which will work the Black Range this summer; would you like the assignment? If so, report to Walter C. Frazer, Chief of Party, at Silver City, not later than May 1. You will receive your present salary of $\$ 900$ per annum with expenses while in the field. The work, it is expected, will last about six months.

"You are perfectly free to accept or decline the offer of this position. I will say, however, that unless you are opposed for personal reasons to tackling reconnaissance, the present chance to learn the methods of this branch of silviculture is an excellent one."

Though somewhat flattered by the offer, my first impulse was to decline it. I had heard much of reconnaissance-the cruising of timbered areas and the topographical mapping of regions usually wild 
and mountainous, often unsurveyed and well-nigh inaccessible. I knew by hearsay that the work was the most trying, physically, of any in the Forest Service; that only the hardiest might hope to successfully undergo the ordeal set the cruiser. It meant, I was aware, living for months on end in camps, a tent for home and the ground a constant couch. It meant toiling daily over brush-covered hills, across malpais-strewn mesas, through tangled thickets of woven thorns and fallen aspen, over jutting peaks or down into treacherous canyons with sides of sheer granite or sliding shale. Day in and day out, I knew, one made his "run" under a blinding summer sun, or in rain or hail or snow, following the finger of the compass wherever it might lead.

Yet I had learned also of the intense fascination the experience held for those who made good and stuck. The very difficulties, the obstacles that arose each day in varied guise, once they came to be looked upon as part of the game, seemed but to whet the appetite of the cruiser for successful performance. The wholesome life in the open, too, eventually hammered the members of a party into a buoyant fitness that was good to contemplate. And then the financial phase was attractive. I had been making both ends just about meet on the ranger district where I was stationed. There would be no chance for a higher salary until fall brought the Civil Service examination for Assistant Forest Ranger. By contrast, the certainty of six months' 
work with practically no expenses, looked good,-if I could hold down the job. As for that, I felt sure that Frazer, whom I knew well, was responsible for this opportunity to join his party and I reflected that certainly he would not have suggested it unless he considered me capable of doing the work. The upshot was that a prompt acceptance, instead of the refusal at first contemplated, went to the Supervisor. Two weeks later, on the last day of April, I reached Silver City and reported for duty.

The others of the party, with a single exception, were already assembled, gathered together from the four quarters of the Forest Service world.

There was first of all Frazer, the Chief of Party. He was a deceptively delicate looking youth with a slender frame that held the strength and toughness of steel wire, and an ingenuous, boyish face which belied his lifelong experience in the open West, among men of all sorts and conditions, in circumstances of ever-varying colour. Five years' work in the Forest Service had won for him the reputation of being one of the best field men in the Southwest.

There was Wallace, a Forest Assistant fresh from Yale, with a plethora of theories and no experience to speak of. Fortunately, however-unlike some of his fellow technical men, just graduated-he realised that his education was not entirely complete, that there are some facts in the science of forestry which can be learned better by actual timber work than 
from books. And we were to find that he possessed a capacity for work and a guileless sincerity that endeared him before long to every one.

There was Bob Moak, a veteran timber cruiser, whose twenty-eight years spent in the woods among lumber camps from Maine to Oregon had made of him a veritable giant of a man, long-limbed and heavy-shouldered, taciturn and reserved, slow of thought and speech, but mighty in action. He knew the look of good timber better than his own features, and though the touch of Time showed in his bowed shoulders and grizzled hair, his experience and woodsmanship made him still a most valuable man for the party.

There was Conway, a former college athlete, now a Forest Guard, and like myself, new to reconnaissance, but with a spare and sinewy build which augured agility and endurance.

There was Bert Gilbert, the noted camp cook, famous throughout New Mexico and Arizona for his flapjacks and "slumgullion." He had just arrived from Flagstaff with a gunnysack of personal effects and a soul-gratifying "hangover" from a recent dalliance with the Demon Rum. Bert, sad to relate, was of that amiable type which finds in the lure of a social glass with friends, and the diversions of the city, temptations not to be resisted. The desire to escape from the burden of this "good fellowship" and so far as might be from his own weakness, had first launched the cook, some years 


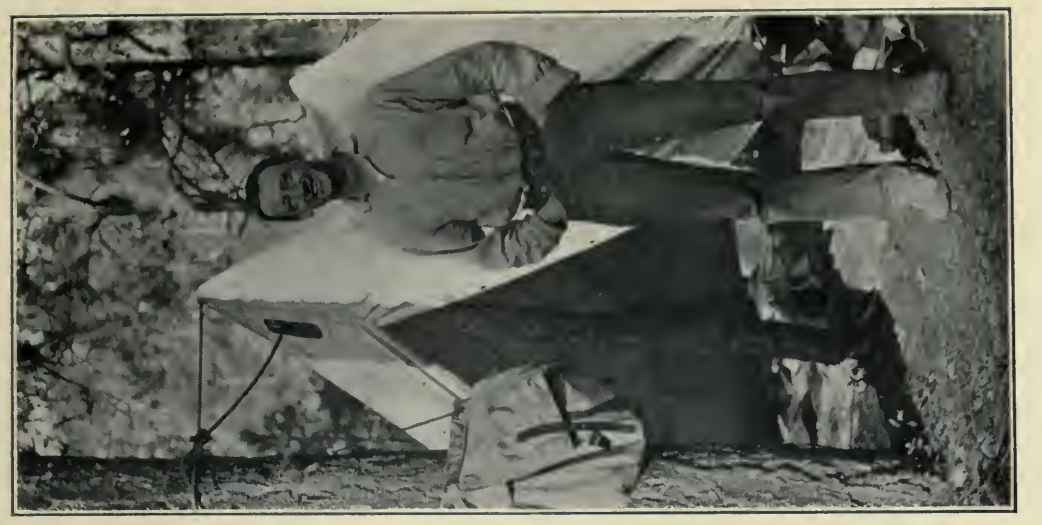

岂

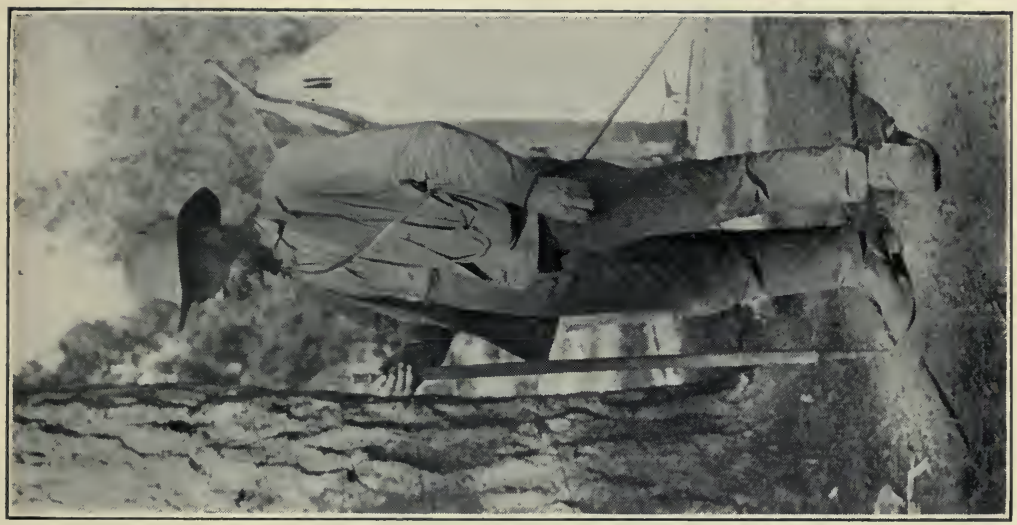

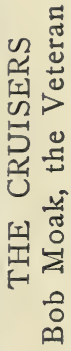

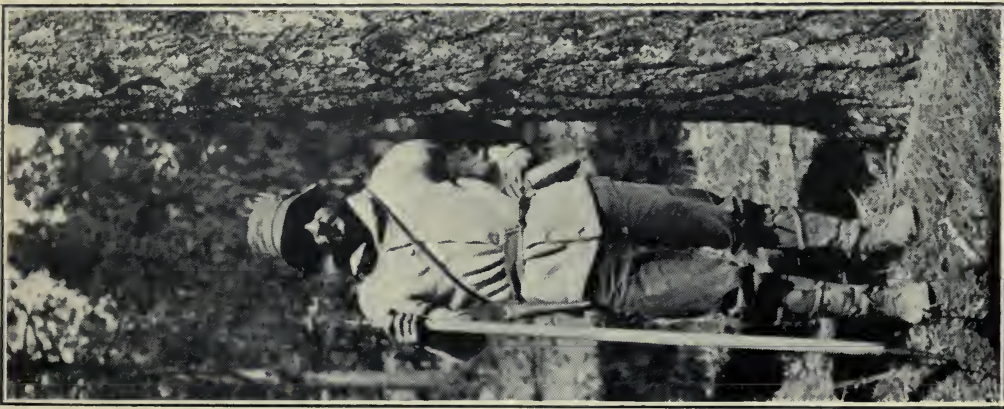

崩 

before, upon the practice of his profession. His continuation in that career was undoubtedly due to periodic lapses from sobriety whenever the outfit with which he happened to be working landed in town.

It was from one of these benders that Bert was just now emerging, with shattered nerves and an intense desire for the simple life. As is customary and appropriate in such circumstances, he earnestly proclaimed it his intention to turn over a new leaf and make our trip a turning point, to use the opportunity afforded by a lengthy sojourn in the forest, far from the insidious highball and the ruinous rattle of chips, to strengthen his purpose of forevermore eschewing liquor and its evil cortége of kindred vices. In his case, I'm glad to say, the threat of reformation was not altogether an empty one although, as will appear, there intervened between its inception and its fulfilment certain circumstances of a rather exciting nature which gave to Bert's decision a virtue of permanence it might not otherwise have held.

The one missing member of the party, Horace Wetherby, was due to arrive on the noon train. We all went down to meet him. All, that is, save Bert, who decided to woo solitude and a new outlook in his room at the Orient Hotel.

We were curious to see what Horace was like. It is only natural to feel some anxiety about the personnel of a group in which one expects to live 
and work half a year, to wish to find out as quickly as possible what each co-worker and companion is like, whether he is to be looked upon as a "good fellow" or a "grouch," a blessing or a pest. No one knew much of Horace or his antecedents. Frazer had, it is true, heard in a roundabout way that the new man was experienced in cruising. But in the matter of his personality we were wholly ignorant.

The train drew in on time, a rare enough phenomenon, and we watched the passengers eagerly. Two cowpunchers got off first. They had evidently been to the city-Albuquerque or El Paso, most likely -and were dressed in gala attire. Everything one wore was duplicated by the other; they were alike as a pair of spurs. Each, perhaps, had feared to draw upon himself the ridicule of the other by displaying any unique detail of town-bought finery. Grinning sheepishly, they greeted a solemn group of friends with formality and shook hands all round in angular, pump-handle fashion. The new black Stetsons, red neckties and polished boots seemed to impart to their friends as well as to themselves an uneasy self-consciousness, and by common consent the crowd headed almost at once for the nearest bar, to dissolve in drink the uncomfortable stiffness of the reunion.

John Ferguson, a cowman, back from a month's business trip, waved to us as he hastened toward his wife, who sat behind a team of restive po- 
nies, welcoming her husband with shining eyes.

Three bored-looking travelling men of widely disparate ages were alike only in that they wore derby hats and walked with one accord quickly and unhesitatingly toward the stage where Big Sam, the negro driver, obviously enjoying the brief but legitimate conspicuousness of his position, rubbed his hands together and shouted at the top of his lungs:

“All abo'd fo' d' Palace-Palace Hotel dis-a-waa-a-y!"

Last to descend, a tall well-built youth with a suit case in one hand and a kit bag in the other, stepped off the train and gazed leisurely about him. As he caught sight of our party he set his baggage on the platform and awaited our approach with great composure. His air was assured, complacent even. It took no psychologist to divine that Horace was thoroughly at home with himself.

"The Forest Service boys, I presume," he observed genially, as we came up. "I knew you in a minute, and I am more than glad to meet you all."

The newcomer was not bashful, that was a cinch. And if his manner had not indicated as much at once, the fact would have become indubitably apparent during the afternoon and evening of that first day. His conversation made that certain. He enlightened us at length in regard to himself and his experiences in the West. We were curious, as I have said, to learn something of Horace. By night we knew all there was to be known. 
He had never worked before in the Forest Service; but while he did not state this in so many words we gathered from his confidences that he was not only letter perfect, so to speak, in the rôle of cruiser, but that anything relative to woods work or camp life with which he was unfamiliar would have to be a very rare, abstruse, and unimportant something indeed.

I don't mean to suggest that Wetherby boasted. He was perfectly sincere. He just gave us the facts about himself as he saw them, in all good faith, and while Bert and Bob Moak considered his utter lack of reticence on the subject of his own history actually unethical, and had no use for him from that time forth, the rest of us were considerably impressed by his revelations.

Frazer, in particular, made no effort to conceal his satisfaction.

"Wetherby's got a lot of 'self-confidence," said the chief that night, "but that's not a bad quality. A few weeks in camp will tone him down, and anyway, it's a secondary matter. As long as he's on to his job we can forgive him the rest. I'm certainly glad he's experienced. Did you notice his build? He sure ought to make a crackerjack cruiser!"

This sentiment fairly expressed the opinion of the majority and no one at the time attempted to dispute its accuracy. We turned in with the comfortable conviction that we were, on the whole, a party of rarely well-chosen and efficient young men. 


\section{CHAPTER II}

\section{GETTING STARTED}

Next day we set out by rail for Hillsboro, a cow town at the foot of the Black Range some seventyeight miles from Silver City. This was our real starting point, where Brown and Ewing, the packers, were to meet us with an outfit of twenty burros and the two horses they needed for "wrangling." For a considerable part of our progress through the mountains would be along narrow trails where wagons are impracticable and where packing with burros is by far the safest and cheapest method of moving camp.

At the station in Silver City, just before starting, an amusing but somewhat disquieting incident occurred. We were busy getting our stuff on the train - each man having a bed of three or four blankets rolled in a sixteen foot "tarp" and a dufflebag full of clothes, when Horace arrived and indicated a formidable pile of bags and boxes as his contribution.

Frazer eyed the array aghast. "What's all that?" he exclaimed.

"My outfit," replied Horace, with pardonable pride. 
No one had thought of calling the attention of the experienced camper to the elementary rule that each man must limit his personal belongings to absolute necessaries. The stuff he had brought would weigh five hundred pounds. The chief thought there must be some misunderstanding.

"Didn't I tell you we were packing with burros?" he asked. "We can't afford to take over a hundred pounds apiece!"

"Well," announced Horace, kindly but firmly, "I've been over my effects carefully, I may say painstakingly, and I really don't feel that I can spare any of the articles $I$ have selected for the trip."

Frazer stared for a brief moment at the bland countenance before him, cast a wild glance at his watch, and without another word dived into the display and began frantically to sort out and separate from the mass those things which he conceived necessary to their owner's continued existence.

An air mattress, a portable rubber bathtub, and a case of dehydrated food went into the discard at once, together with a large and miscellaneous assortment of fishing tackle and sportsmen's clothes. As these were augmented by a chest of medicine, a cork helmet, and a neat little set of "Camper's Classics" bound in green morocco, the indignant Wetherby protested volubly.

Frazer ignored him until his task was finished. Then he straightened up. 


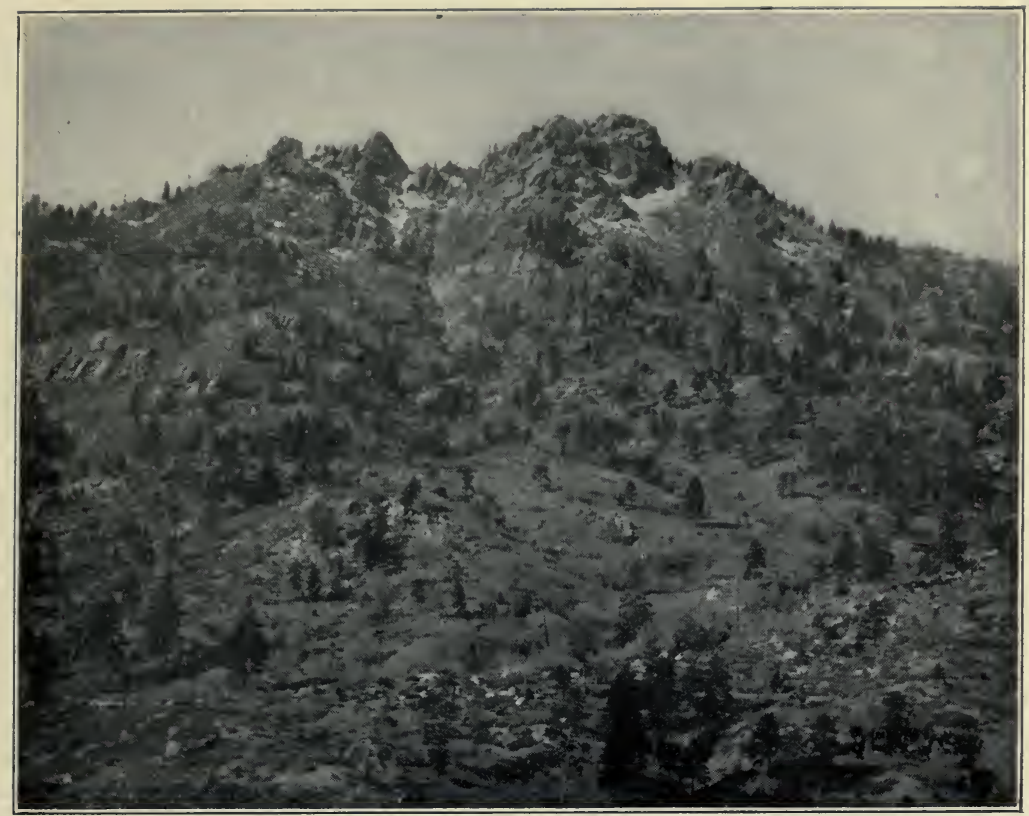

The Cruiser Climbs High Peaks

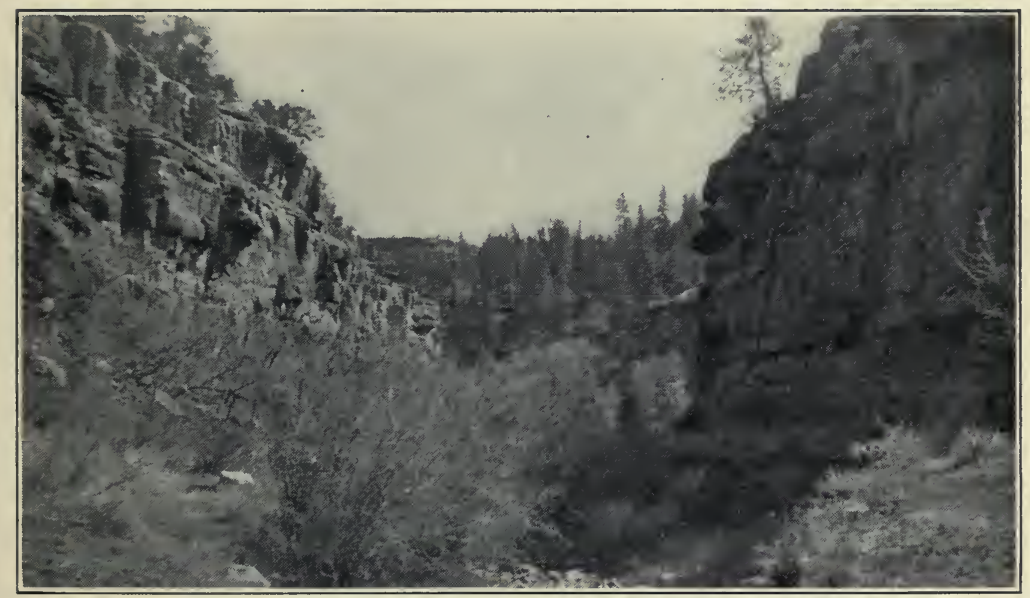

Or Descends Into Yawning Canyons 

"Those things there," he said, pointing to the larger stock, "will go back to your hotel. These here," and he indicated a forlorn little pile of bedding and clothes, "will go in the train with us. You'd better toss them on quickly, because we start in three minutes."

He turned and clambered on the train, leaving Horace to struggle with his repacking alone. This was unwise, as it turned out later, for in the process he managed to slip enough medicine, books, and dehydrated vegetables into his bed to earn for himself the undying enmity of the packers and doubtless of the capable little burro whose lot it was to carry the load through the fastnesses of the Black Range.

The incident had the effect of casting a temporary shadow over the bright impression Horace had produced the day before. I noticed that, from time to time, Frazer eyed his "crackerjack cruiser" during the journey to Hillsboro with a puzzled, disappointed look which held more of sorrow than of anger.

We arrived at our destination the following afternoon and were met at the station by Brown, whose countenance was positively lugubrious.

"What's the matter?" queried Frazer sharply. "Anybody dead?"

Brown's expression became, if anything, more gloomy than before.

"He's on one," he remarked succinctly, jerking 
his thumb backward in the general direction of the Sample saloon, from which, despite the time of day, issued unmistakable sounds of revelry. We began to connect the missing packer, Ewing, with Brown's despondent air, and started en masse for the scene of action.

Frazer called a halt.

"You two fellows," he said, to Brown and myself, "come with me. The rest can get the stuff over to the hotel and arrange for supper and rooms. We'll stay here to-night."

We found Ewing the centre of an admiring throng of cowpunchers. He was seated on a table in the centre of the bar room, very drunk, and playing a violin with remarkable skill. Frazer decided that there would be nothing gained by an untimely interruption, so we joined the audience and listened for an hour to as really excellent a performance as I have ever heard. The music ranged from popular airs to classical arias, from the "Arkansas Traveller" to Dvorák's "Humoreske." The crowd was delighted; now silent, spellbound, now moved to the wildest enthusiasm. Accustomed to the squeak of a phonograph, or the clumsy efforts of some local "fiddler" whose ambition ceased at "Listen to the Mockingbird," the men were enthralled by this wonder.

"Been here a week and we never knowed he could play a lick," shouted one husky cowman, regretfully, "that's what comes of a man keepin' sober!" 
"We sure ought to have a baile before he leaves," suggested another.

The idea met with instant approval. Riders leaped to waiting horses and left at a lope in all directions to seek partners for the dance.

We seized upon the opportunity created by this diversion to approach Ewing. The musician greeted us quietly, lazily cordial. He appeared not at all embarrassed by the circumstances of the meeting. I was surprised at his nonchalance, surprised, too, when he spoke, by the purity of his accent, beneath the veneer of cowboy slang, and the unmistakable hint of refinement in his features, marred and dulled though they were by the ruthless hand of dissipation. It was immediately apparent that the packer was a man apart from his present fellowsa "gentlemen ranker" to all appearances-at once better and worse, but always different from the rough, good-natured world in which he moved.

Though patently intoxicated now, he gave no offensive evidence of his condition. His voice was low and well modulated, his manners, though a little too deliberate and exaggerated, were otherwise perfect.

Frazer, after complying with the formality of ordering drinks, diplomatically complimented the musician upon his playing.

"I should think you could make a pretty good living with your violin," he finished.

Ewing frowned. Then his countenance cleared with startling suddenness. 
"I could," he laughed. "I ought to be able to! I've worked at it most all my life. But," he added blandly, ignoring the question in our eyes, "I'd rather earn my living as I do.... Let's have another, what do you say?"

Frazer shrugged his shoulders. As we lined up at the bar he said, casually, "We move to-morrow, you know, Ewing!"

"Yes, I know. I'll be on deck all-right. I've got to play for the dance to-night; the boys expect it. But I'll be on the job in the morning. Better come on over this evening," he added, as we turned away, "you and the rest. You might see some fun."

None of us, however, accepted the suggestion. We decided to enjoy instead a last sleep "between sheets." But we heard until late the shuffle and stamp of feet, the shrill laughter of women, the deeper, louder voices of the men, and through the confused medley of sounds the singing of Ewing's magic violin, sweet, insistent, weaving its living melody, making articulate in many tones the determined, fleeting joy of the dancers. 


\section{CHAPTER III}

\section{THE FIRST DAY'S WORK}

BEFORE starting out from Hillsboro we branded the pack burros. They were all "broncs" caught wild in the hills and quite unmanageable. The job, in consequence, was fraught with a certain amount of excitement. Since we were anxious to be on our way, every one-including Ewing, who showed up bright and early, apparently none the worse for his "day of rest" - turned in and helped. But it was, notwithstanding, a matter of considerable difficulty to rope and hog-tie the score of restive jackasses and to hold down each one in turn while the packers, who wielded the branding irons, seared a large "U. S." on the neck of the prostrate "jack" or "jinny."

Wetherby, of us all, took the occasion most seriously. He approached the conflict with a purposeful mien worthy of a crusader, and expended a tremendous amount of energy during the morning; though his chief utility lay, after it was all over, in having furnished us with a laugh that lingered in our minds many a day. He elected in the beginning to wield a rope, alleging familiarity with the art, but the astute burros eluded his feverish casts with 
careless ease, ducking perfunctorily whenever the loop by any chance threatened to fall in the vicinity of one of their number. Whereat Horace would carefully recoil his rope and swear mightily. $\mathrm{He}$ was, he assured us, a "fearful blasphemer."

After a time the unsuccessful roper decided that his methods were too precipitate. He selected an inoffensive-looking jinny with drooping ears and began a policy of stealthy and insidiously slow advances. He stalked his victim, infinitely cautious, until within a few yards, then with a yell of triumph rushed upon her and holding the noose in both hands dropped it over her head.

"I've got one! I've got one!" he shouted, much as an angler hails the landing of a three-pound trout.

But instead of driving his captive to the fire he attempted to lead it, a procedure to which the burro is notoriously averse. There was a brief but fervid tug of war. Horace and the jinny, a few feet apart, glared into each other's eyes and strove fiercely. It was indubitably a draw, since neither moved.

Wetherby, however, now thoroughly aroused, was not to be denied. He looped his rope around the burro's nose, shutting off her "wind," and the struggle began anew. Half suffocated, she advanced perforce a few short steps; the rope slackened suddenly, and Horace stumbled and fell full length upon his back. This manœuvre, practically simultaneous with the burro's forward movement, convinced the alarmed youth that he was being attacked. He 
promptly released the rope and waved his legs frantically in the general direction of the enemy, crying lustily: "Oh, the little Devil! Help! Help!"

We finally persuaded him that he was in no immediate danger, and he allowed himself to be assisted to his feet, none the worse for his harrowing experience.

It was evident, however, that as a burro-puncher Horace could not be considered an unqualified hit. We were all greatly edified by the affair, with the exception of Frazer, who eyed Wetherby gloomily enough. He was apparently approaching a state of pessimism concerning his protégé's complete efficiency.

In the afternoon we saddled and packed the twenty burros with tents, beds, dufflebags and supplies, weighing altogether over two thousand pounds. It seemed marvellous that the little beasts could stand up under their loads. We had yet to learn that the burro, for its size, is the strongest, toughest and most tireless of pack animals.

By the time our preparations were completed, there was not over three hours of daylight left, but by dint of pretty constant effort on the part of the packers we drove our outfit eight miles to Kingston and made camp before darkness fell.

During the trip we discovered that Brown and. Ewing had already found names for the burros. Some of these appellations were amusingly descrip- 
tive of personal peculiarities, others had been seized upon because of a fancied resemblance the animal designated bore to some friend or acquaintance of the boys. Thus "Miss May," a large, dignified jinny, was so christened on account of a striking likeness, in port and expression, to the buxom proprietress of a local restaurant. "Mallet Head," "Pepper," "Curly," "Red," "Beetle" and "Methusalum," were so styled for various qualities or defects which caught the fancy of the self-appointed committee on titles. "Whitey," the jack, who looked like an albino, was in the days that followed' far more often called by some other and less elegant term than his given name. A persistently perverse ego, in which he gloried, was responsible for more mislaid tempers, I think, than any other one item in the catalogue of daily trials.

We found Kingston merely a melancholy collection of deserted buildings. Some of these were quite evidently the ruins of rather imposing structures of brick and stone. Across the front of the largest of all, in faded letters, were the words "Board of Trade." The place seemed inexpressibly lonesome and cheerless, although in its day Kingston had been a thriving mining camp of five thousand souls. But with a drop in the price of silver and the closing of the larger mines the city had been snuffed out like a candle.

Now there were but three families living within its limits-the Postmaster, an old miner who did 

assessment work on some of the claims, and Jackson, the Forest Ranger, who made the place his headquarters for administering the ranger district of which he was in charge.

We stayed over a day to find an established section corner and to frame a plan of campaign with Jackson, who of course knew thoroughly the country we were to work. He was able on this account to give Frazer information which later proved of great value. For the region we were entering is conceded to be as consistently rough a country as can be found in the Southwest, and an accurate knowledge of possible camp sites, springs, and trails was a very necessary prerequisite to our actual invasion of its strongholds.

The Black Range is physiographically a division of the Arizona Highlands System. As such it extends a considerable distance north into the Datil National Forest. But locally and for the purposes of this chronicle the name is applied to that high main ridge, with its timbered watersheds, which runs due south from the Datil line forty miles to the lower boundary of the Gila National Forest, where it sinks gradually to the level of the surrounding practically treeless country. The width of the timber bearing area varies from five to twenty miles, so that we had to plan to cover a tract of some four hundred square miles in the speediest and most economical manner compatible with thoroughness. The chief matter for decision was the course of a 
baseline, for upon this would depend our route and the manner in which we would approach and cruise the various divisions of the range. This baseline, we learned, was simply a surveyed line running from the nearest established section corner to the camp where we were to begin work. This accounted in great part for our stop at Kingston, where the only known corner for miles around was located. After carrying the baseline to the first camp it would follow the ridges or canyon bottoms-wherever the going was easiest-according to whatever plan Frazer devised in regard to the general scheme of our work. The baseline, Frazer said, would be plotted out on township plats, carried for the purpose by the instrument man, each day as we went along. Since it was to be tied in with the section corner at Kingston it would-assuming accurate computation-enable us to ascertain our exact location as regards section and township at any time, and all other work would be carried on with reference to it as a guide.

The outfit used in carrying forward the baseline, we found, consisted of a plane table, an alidade and a stadia rod. The plane table was a flat, smooth plane of wood an inch thick and about two feet square, which screwed onto a heavy wooden tripod with spike-tipped legs. The alidade, which when in use was to be set upon the plane table instead of upon a tripod of its own, turned out to be an instrument like a telescope with several mysterious looking little attachments in the form of thumbscrews 
and ares with degrees measured off on them, and a thin flat metal base about two inches wide and twelve long. The stadia rod, which would be carried in advance, to sight upon through the telescope part of the alidade, was just a long straight slab of light wood an inch thick, four inches wide and twelve feet long; with a strip of linoleum, painted across with red stripes an inch apart and having black numbers to mark the feet, tacked on one side.

Aided by a general map of the forest and Jackson's familiarity with conditions in his district, Frazer succeeded at length in drawing up a sort of baseline itinerary, subject of course to frequent changes in the field as conditions should later dictate; though our immediate plans were fairly simple. Kingston lies, as I think I said, at the foot of the eastern slope of the Black Range, some four miles from the top of the range and about three quarters of the way along the range from the Datil boundary. So it was decided to work the short southern end of the range first. The baseline Frazer proposed to carry at once from where we were to the top of the main ridge, straight away. Then south along the top, while the cruisers worked east and west from it until we reached the southern limit of timber. There the proposed course swung westward in a horseshoe curve and turning north again tapped the timbered country on the west side of the range, over the divide, until we got far enough north to come abreast of our first camp west of Kingston. 
This having all been settled we started work next morning. Jackson showed us the re-established corner near his station, where the baseline was to begin. We all went along this first day to get an idea of how the line was run, but the crew selected by the chief for this department did most of the work.

The baseline crew consisted of three men. To Wallace was assigned the unenviable position of instrument man. It would be his privilege, in addition to his regular duties of using the instruments and making the necessary computations, to carry the plane table and alidade all day on his shoulders, a task irksome at best and in rough going an almost intolerable burden. Nevertheless he subsequently toted his unwieldy outfit well over a hundred miles of baseline before the season ended, to say nothing of the walks from camp to work and back; and no one in all that time ever heard him register so much as a whisper of complaint or self-sympathy.

Conway was chosen rodman. His duty was to go ahead and set up his stadia for each "shot," as a reading of the alidade was termed, on the spot he thought would afford the best sight for the instrument man. His post required a person of considerable discretion, according to Frazer, since the longer and more direct each shot could be made the quicker would be the progress of the work.

An axeman was needed to complete the "baseline bunch," to blaze the line, set stations for cruisers and cut out brush or small trees when this was 


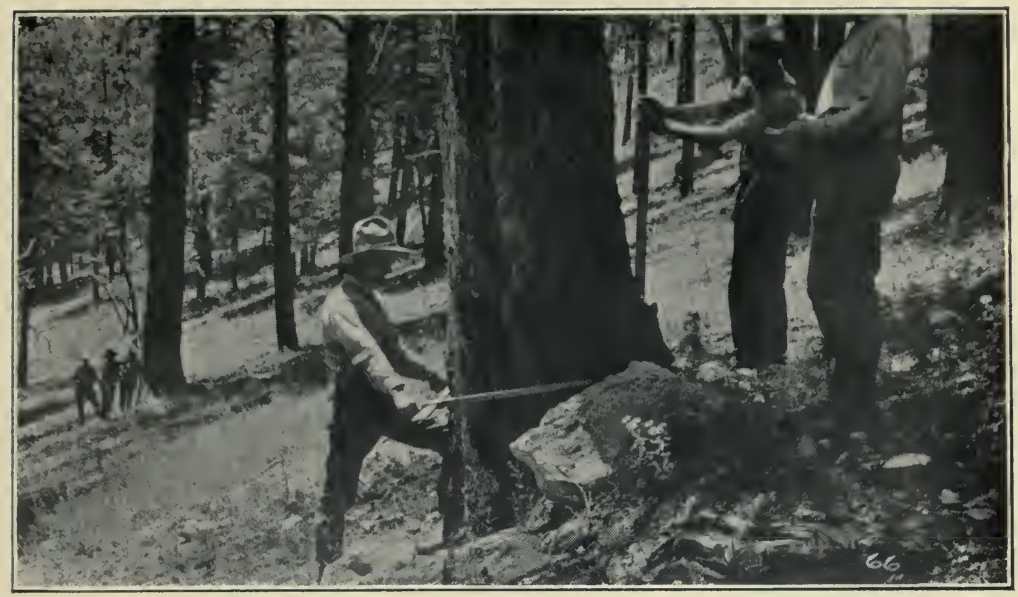

SAMPLE PLOT WORK

Wetherby holds the calipers

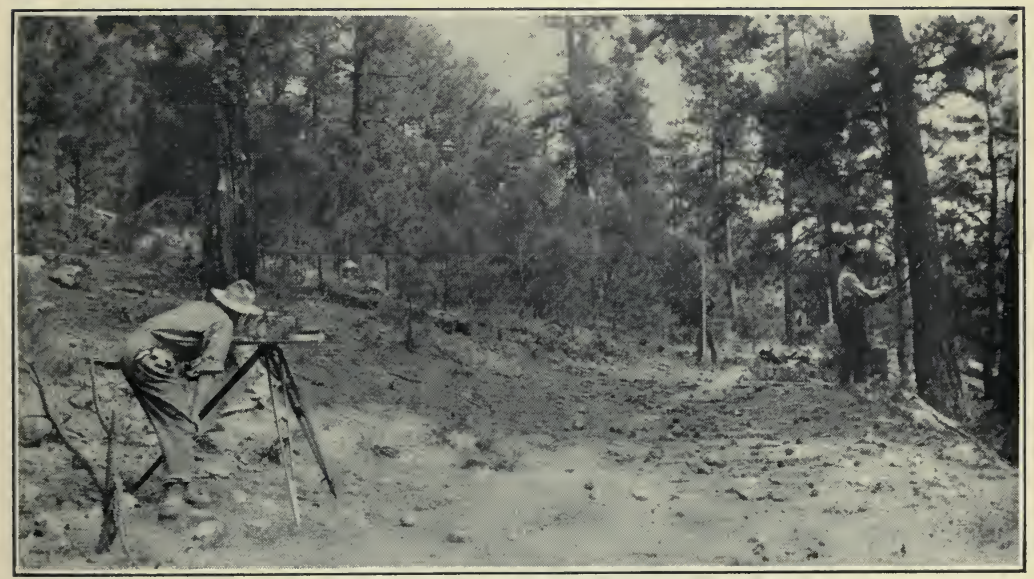

EASY GOING FOR THE BASELINE CREW

Wallace at the plane table, Brown blazing the line, Conway with the stadia rod in the distance 

necessary to give Wallace a better sight on the stadia. Brown undertook to hold down this job until the rest of us had been tried out as cruisers.

We watched the first shot of the season with interest. Wallace set up the plane table directly over the section corner Jackson showed us and fastened a blank township plat on the table with thumb tacks. He wrote the number of the township we were in at the top and marked down in its proper location on the sheet the section corner by which we stood. We knew now where we were on the map as well as on the ground.

From this point we were to trust Wallace. He understood the system of township mapping and surveying and as often as we would work over the edge of any plat on the plane table with the baseline, the sheet would be removed and the plat for the particular township we were about to enter would be substituted. Thus at the end of the season, Frazer told us, the course of the baseline would be represented by a zigzag line (each zig or zag a shot of the instrument) running across township after township until the cruisers, working out from it, had covered the whole Black Range area.

It is well to state here that in properly surveyed country, where all or most of the section corners are established, this problem of a baseline need not have bothered us at all, for in that case we could have based our work on the survey, starting each day at an established monument and "checking in" for ac- 
curacy at each corner we passed throughout the day. But though a part of the Black Range country had been surveyed sometime in the dim and distant past, corners were scarce as hens' teeth, not worth looking for, and a baseline was eminently necessary if we were to know at all "where we were at."

To return to our first shot. When the plane table was set up, the township plat tacked on, and the position of our corner marked, Wallace carefully removed the alidade from its case and set it on the table. Then he placed a Forest Service regulation compass on a corner of the table, its sides flush with the two sides of the table that joined at the corner, and fastened it in place with thumb tacks. He then "orientated" the compass by turning the table, that is, made the sights of the instrument point due east so that the sides of the table faced squarely south, north, east and west. The oblong metal base of the alidade was placed so that the telescope of the instrument pointed northward, in the direction we wished to go, and the rear right hand corner of the base was set accurately at the point which marked the section corner where we were at the time,- - the reason for which will appear presently.

Conway had in the meantime gone forward as far as he could without being hidden by brush, trees, rocks or the conformation of the ground. After waving him into the field of the telescope by a set of prearranged signals, Wallace then sighted at the stadia rod through the lens, and by various manipu- 


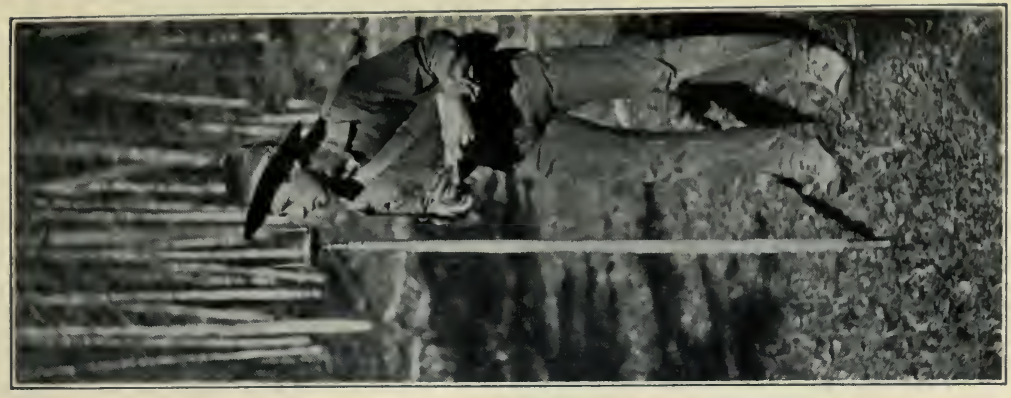

苞

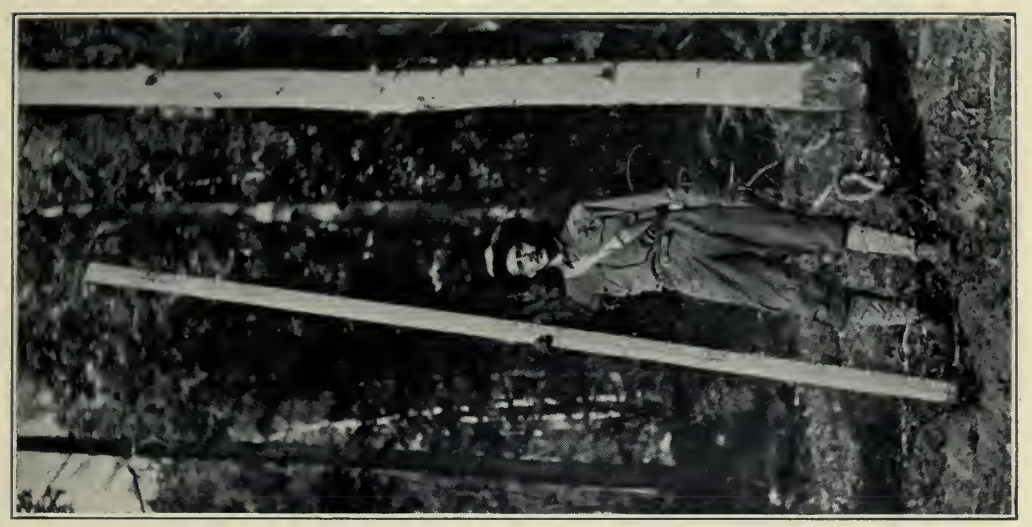

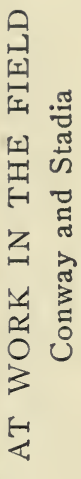

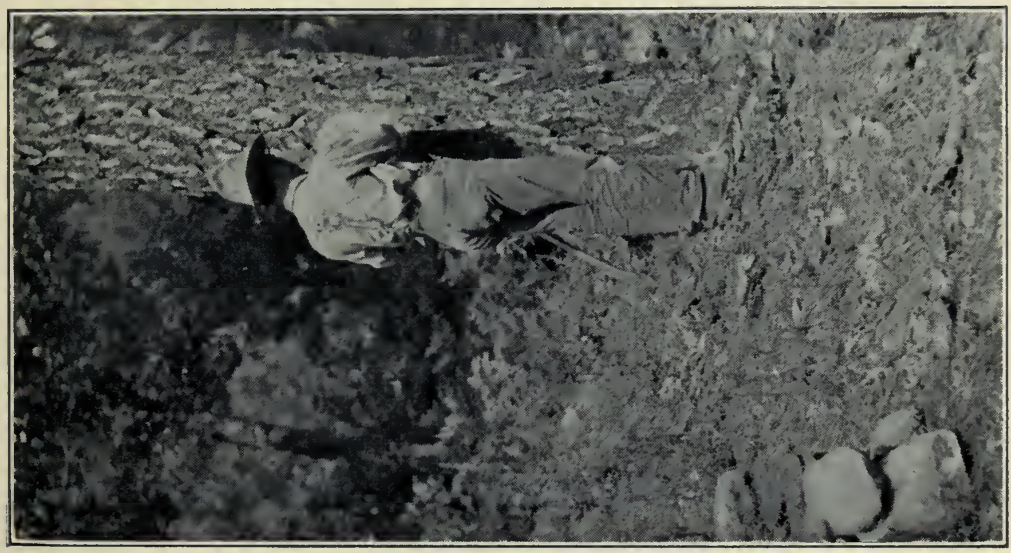

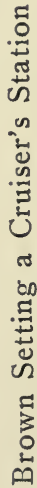



lations of the thumb screws and a few mild expressions of self-exhortation, finally succeeded in fixing the junction of the two cross hairs on the lens upon a point on the rod. When he had noted down a few figures he waved Conway to desist and the latter thereupon marked the spot where the base of his stadia had stood with a stone and sat down to rest until we came up.

How he did it I don't know, for I'm not and never hope to be a mathematician, but by consulting the scale on the arcs of his instrument and a little leather covered book of tables and formulæ, and after making sundry feverish calculations on a pad of scratch paper, Wallace presently announced that we had progressed (by shot) two hundred and three feet, and that the elevation of our next set up-where Conway was-would be eight feet higher than where we stood. The alidade, it appeared, had the mysterious faculty of revealing both distance and increase or decrease of elevation to the operator.

And this was not all. We were to see now the reason for placing the corner of the base of the alidade on the point on the township plat which represented our present location. With a finely marked rule Wallace measured the distance of the shot, changed to the scale of the plat, along the base of the alidade and stuck a needle-pointed instrument like an awl into the plat at a point corresponding to the spot where Conway sat. Then he drew a pencil along the paper, between the two points, using the 


\section{THE LOG OF A TIMBER CRUISER}

alidade base, which ran in a direction exactly parallel to the sights of the instrument, as a guide, and removed the instrument. There, as plain as lead could make it, was our first shot-made, plotted, and drawn. It wasn't a very long one, but it seemed rather wonderful to us. We did nothing like this that first day. Our progress all told, I believe, was scarcely a mile. The campaign, though, was at last under way, we were at work and learning, and every one was cheerful, confident, and in the very best of spirits. 


\section{CHAPTER IV,}

\section{SAWYER'S PEAK}

We moved on the following day to the top of the range. Our first camp was on the east side of Sawyer's Peak, a well-known local landmark. And whereas at Kingston the elevation was 6,300, at camp we made the altitude just 9,300 feet above sea level.

While the baseline was being brought up a couple of days were devoted to "sample plots." An area (usually ten chains square) was measured off on the ground with chain and compass, the diameter of each tree thereon calipered, the timber in feet board measure estimated from approved volume tables, the reproduction tallied, and notes on miscellaneous silvical data of interest recorded.

These sample acres, a welcome respite to the cruiser, were afterward taken at intervals throughout the season. The work was valuable not only for the collection of silvical facts, but for the purpose of checking the figures of individual estimators. By comparing the appearance of the stand on such plots with that found on his run a cruiser possessed a standard for sizing up timber which tended to greatly increase the accuracy of his estimates. Especially was this experience worth while to those of 
us who were new to the work. We could scarcely have undertaken to cruise without it.

And indeed, even experienced timber workers find it necessary to get some such line on how the trees run, in feet board measure, when they enter an unworked region. In the Black Range the frequent taking of sample plots was particularly necessary on account of the constant variation in altitude and the consequent change of species and quality and amount of timber.

In general the best stands of Western Yellow Pine, which is the chief, or technically the "dominant" species of the forests of the Southwest, are usually found at between 7,000 and 8,500 feet altitude, though scattering trees grow in the canyons as low as 6,000 feet and on slopes with a southern exposure as high as 10,000 feet above sea level. But at these higher levels, generally between 8,500 and 9,500 feet, the dominant type is a composite of Douglas Fir and Western Yellow Pine. Along creeks and on north slopes one is apt to discover that Douglas Fir and White Fir have crowded out the pine entirely, and compose practically the whole stand in such places. At 9,000 feet Engelmann Spruce appears, and above 9,500 feet this species predominates, with perhaps a smaller stand of Alpine or Cork Bark Fir present as a secondary species.

Since our work in the Black Range took us during the season through altitudes varying from 6,000 to over 10,000 feet we encountered at one time or an- 
other each of these varieties of timber and every type of condition and site quality, and a known basis, continually re-established, for computing timber values was practically indispensable. Whenever we moved, therefore, from one locality to another, we took these sample plots as an almost invariable preliminary to actual cruising.

At our Sawyer's Peak camp we arranged the matter of tent-mates, for the seven by nine sleeping tents that we carried were each easily large enough for two. Frazer and Bob Moak, who had worked together before, elected to renew old-time relations and bunk together. Brown and Ewing naturally gravitated to the same tent; Bert slumbered in solitary state under the big fourteen by sixteen cook tent, and Conway and myself undertook to share a "canvas cave" for the season. This left Horace for Wallace, who did not seem overcome by the honour, but he accepted the situation sans argument, with customary good nature.

Once settled, our tents set and ditched, we examined the surrounding country with considerable interest, for cruising was imminent. We would have much preferred to start in on easy country but the prospect of "pickings" appeared slim. From camp we could see for miles in every direction. The view to the eastward, from Sawyer's Peak, was superb -or "fierce," according to what one sought. Yet though we examined it through eyes prejudiced in favour of gently rolling slopes and shallow draws, we 
could not but admire the gigantic abandon with which the tall cliffs broke away in ragged bluffs and ridges of rim rock, the sweep of the towering timbered ridges, the sinister depth of great yawning canyons, haunts of the grizzly and the mountain lion.

I remember one evening especially when this matchless panorama produced an impression upon me that still remains vivid and undimmed, with all the wild grandeur of outline and delicacy of colouring that made the original unique in my experience.

Frazer and I had strolled out to Lookout Ledge, a little rocky point near camp, just at sunset. The broad forest falling downward and away before us stretched grandly, a mass of moving green, to the timber line. Beyond, rolling yellow hills tumbled and sprawled, lower and ever lower, till they melted into a velvet plain with the tiny silver vein of the Rio Grande winding across like an attenuated, shining snake. Further yet, beyond other plains, faintly visible, rose the uneven, misty line of the San Mateo mountains, fifty miles away as the crow flies. The sky and the air were alive with a warm, marvellous afterglow. It subdued the harsher features of the scene, touched the hills and valleys with wonderfully soft pastel shades, and made the wavering outline of the far-off range throb and glow with magical opalescent hues, like the Mountains of Dream.

I had been completely lost in this vision, when Frazer's voice brought me back with a jerk. 


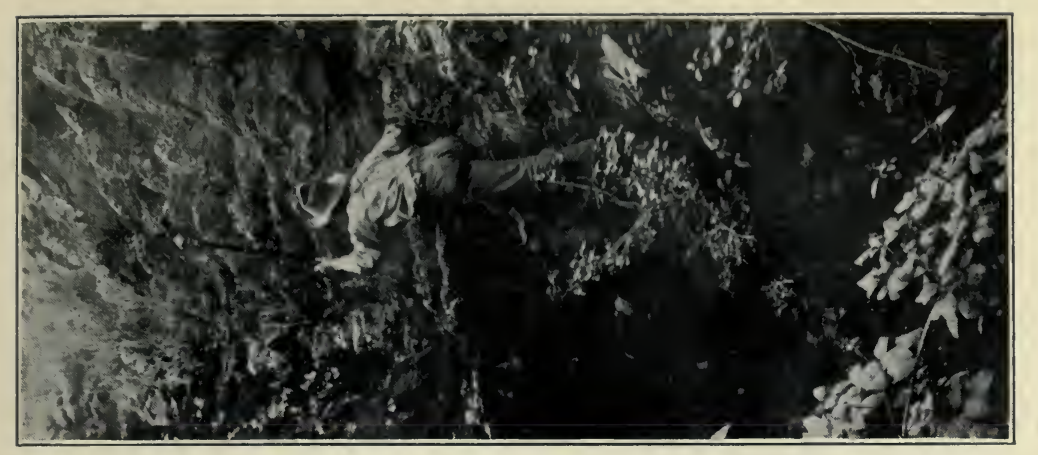

苛

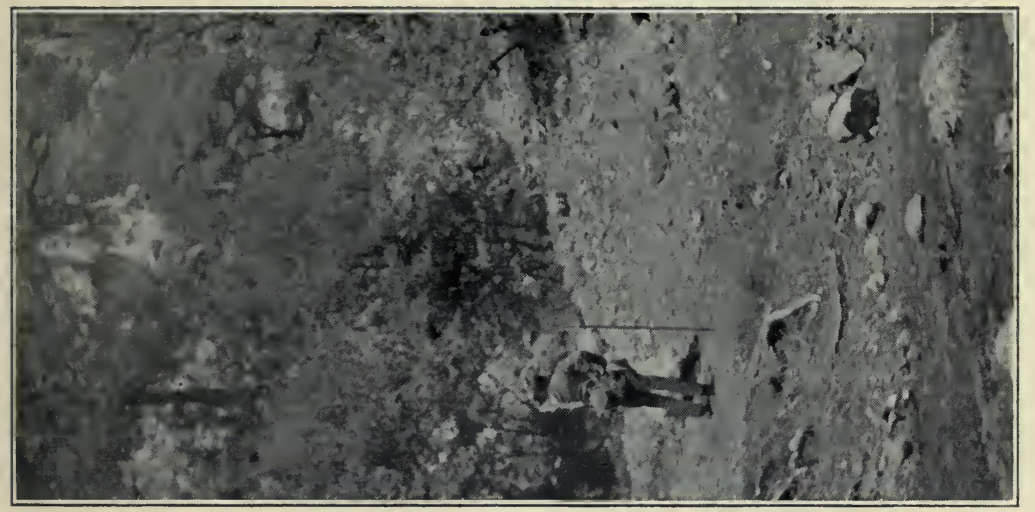

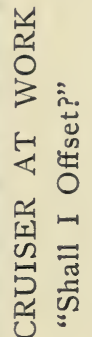

퍼

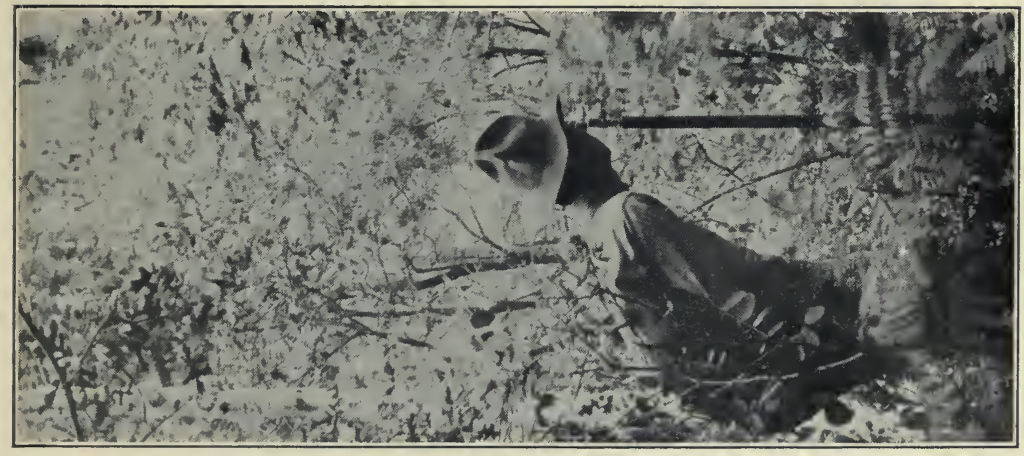

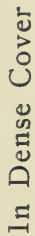



"We've got our work cut out for us here," he remarked casually. "Look at that canyon down there. Isn't it a corker?"

My exalted mood vanished as completely as died the light on the distant peaks. I gazed on the scene with new eyes. The spectacle that a moment before had been inspiring, full of a vague, beautiful promise, was gone. In its place loomed a land of menace and mystery. The darkening hills seemed to frown ominously, the forest, gloomy and vast, to hold dire threats, the rocky canyons to hide dark secrets, grimly guarded from profanation by man. For a moment a feeling of awe akin to fear swept over me. I felt small and quite insignificant. For the first and only time during the season I wished heartily that I were well out of the whole business.

Frazer glanced at me and laughed.

"Don't get scared," he said; "you'll live through it. Everybody who starts on reconnaissance overestimates the difficulties. You mustn't let your imagination run away with you. One thing above all you've got to remember: don't let any little bit of striking scenery get your goat 'til you come to it. You'll often see ahead what appears to be a straightaway cliff, but when you get there it may turn out to be an easy slope. Besides, if you can't manage to get over a bluff or peak you can offset a few chains and go round it."

This sounded all right but I didn't feel much bet- 


\section{THE LOG OF A TIMBER CRUISER}

ter. I was simply in a funk, that was all there was to it.

"Is there much of it like this?" I inquired feebly. "Well," replied Frazer, with chilling cheerfulness, "the Black Range, as a whole, is considered about the roughest country in the District. I've been over a good deal of it in a preliminary survey and, while some places are better than this, some are worse. The Animas Canyon region, for instance, is a fright. But just forget about the future! It's not here yet. Take each day and each run and each chain that you pace as it comes, and you'll find it will all work out. You'll have to get on to pacing and sketching contours first. That will keep your mind busy for the time being. To-morrow we'll try a run. Bob and Wetherby have cruised before, so they can work alone, and I'll take you out with me. It will be the easiest way for you to get on to what you need. You won't have any trouble learning. Take my word for it, in a few weeks you'll look back at to-night and laugh at yourself !"

"I hope so," I answered, and tried to speak convincingly, though the strength that conviction gives to words was, I fear, wholly lacking. 


\section{CHAPTER .V.}

\section{CRUISING}

WheN Horace emerged from his tent in the morning his appearance caused something of a sensation. The veriest tyro in reconnaissance knows that lightness of apparel and accoutrement is the first care of the cruiser. Frazer, for example, besides his instrument and notebook, wore simply. shoes and socks, hat, shirt, and overalls. Some of the men carried a canteen and revolver as well. But Wetherby. was a picture in khaki riding breeches and knee boots, waterproof hat and heavy shooting coat. Around his waist was a huge cartridge belt filled with ammunition. To this were hung two wickedlooking Colt army revolvers and a hunting knife. The capacious pockets of his coat bulged with medicine, bandages, and condensed food. A canteen was slung under each arm and a rolled poncho tied across his back, though the rainy season was a month away.

Frazer stared a moment, dumbfounded. Then a hopeless look came over his face and he said mildly:

"Aren't you giving away a trifle too much weight, .Wetherby?"

"Oh, no!" Horace assured him. "In Colorado 
I've often carried double this amount. I'm very strong!"

Nothing further was said, and the tall cruiser strode off with the rest of us to our stations.

These cruising stations, indicated by a monument of stones and a witness blaze on a nearby tree, on which the number of the station and the elevation are inscribed, were set every twenty chains along the baseline, beginning ten chains from the first section corner. Thus the cruiser, starting at a given station and running at approximately right angles to the baseline, in cardinal directions, travelled through the middle of a tier of "forties," or fortyacre section subdivisions. The forty is the unit for timber estimates; and by mapping and estimating for ten chains on either side of his course as he advanced, a man covered a forty-acre tract as often as he paced a quarter of a mile ahead.

At the end of the outward trip he would offset twenty chains from this line, in a direction parallel to the baseline, and cruise back through the adjoining tier of forties, checking in at the station beyond the one from which he started. Each run, therefore, disposed of a strip of country half a mile wide and as long as the character of the running permitted.

On the day of which I speak Bob Moak ran out from stations one and two, Horace took three and four, while Frazer and I went on to station five, where our work began. All were east runs. 
We had taken full cruiser's equipment: A Forest Service standard compass, "Jacob's staff," aneroid barometer and notebook; and our first move upon reaching our station was to set the aneroids at the elevation recorded there, ninety-two hundred feet. Then, as we rested a few moments before starting out, we discussed the details of the run.

I had learned by now something of the general character and methods of our work. I knew that reconnaissance was a sort of forest stock-taking-a gathering and tabulation of the resources of the forest. The timber estimates of the cruisers, the topographical maps, and the silvical data compiled by our party, for example, would serve as a guide to the Supervisor in planning and carrying through future timber sales in the Black Range. And when all the timberland on the Gila had been cruised, the mass of information collected would form the basis for a Forest Working Plan outlining the policy of management-the methods of administration advisable in the light of the facts reconnaissance might discover and submit.

This much I knew. The process of collecting the necessary data - the actual work of cruising-was Greek to me. And now my initiation in that phase of the subject began.

Frazer handed me a little oilcloth-bound book which just fitted in the hip pocket of my overalls.

"Here's your field notebook," he said.

On every lefthand page there was printed a sec- 
tion plat, four by four inches, ruled into sixteen squares representing forty acres each. At the top of the page space was given to note the number of the range, township, and section, the name of the watershed, the date, and the initials of the cruiser. On the righthand sheet was the form in which timber estimates were set down-sixteen squares corresponding to the forties of the section plat whereon the map was to be made. Below, at the bottom, across both pages, a place was left for a description of the whole section; the character of the surface and soil, rock and ground cover, the condition of the range for cattle or sheep; the logging possibilities; the species, quality and condition of the timber; the extent of burned-over area, if any; and other miscellaneous information of silvical interest.

"Your map," continued Frazer, when I had finished examining the notebook, "must be drawn in hundred-foot contours-one at every hundred feet as you go up or down. The elevation is found, of course, by your aneroid. You indicate also trails, roads, fences, houses and similar features whenever they occur, by the symbols in the forest atlas. You'll just have to learn them as you go alongthey're easy enough. Your contours will give you some trouble, though, at first. About the best way of judging how they should run is to imagine that a body of water has risen to the elevation at which you stand. The shore line of such a sea, seen for ten chains on each side of you, would mark the 
course of the contour used to express that elevation as it extends through the forty which you are mapping. You've got to always remember that a forty is twenty chains square, and get used to the scale of your map. Note how a chain, or five or ten chains look, when you draw them to scale.

"As for the question of estimates, that, like pacing, is a matter of practice. Your figures will all be made on this job from an ocular estimate. You've got an idea from our sample plot work what timber looks like when it runs a thousand, two thousand, or whatever number of feet it does run, to the acre. As you go through each forty you've got to judge the average run for each species in feet board measure and set it down in its proper place in your notebook. The same holds good as regards the description, only that's made out for the whole section instead of just the forty.

"But don't expect to learn it all to-day. It will be some time before you get the hang of it. It's just like other lines of work. The only way to learn, once you know what you're trying to do, is to get out and do it!"

With this he stuck his iron-shod. Jacob's staff in the ground, set up his compass atop with the sights set due East, and off we started. Our course took us almost straight downward for some four hundred feet to a wooded draw in the bottom of the first canyon. Then up again over a ridge a little lower than the main one. Then down again, then 
up. The going was hard and our wind as yet none of the best, but we took things easy.

I found pacing the hardest problem to solve. All reconnaissance work is done on the basis of distance as measured by the cruiser's steps, and in mountainous country this is no easy job. Every one, in beginning, has to discover how many of his paces will carry him sixty-six feet, or a chain-the unit of measurement-and how much to allow when travelling up or down grades of various degrees of steepness, since of course only the horizontal or air line distance is considered. At first I couldn't get it at all. And my map, despite Frazer's hints, was hardly a thing of beauty. But before the day was done I had learned what to do, if not how to do it, and as the hours passed I found my timber estimate and contours were approaching Frazer's somewhat more closely than in the beginning.

By noon we had paced out a mile and a half through a tier of six forties. We found ourselves in a wooded canyon through which ran a small stream, so we improved the opportunity by halting for lunch and a smoke.

This respite in the day's work is one of the cruiser's most cherished privileges. Whether or not the surroundings are as propitious as were ours on this first day's run does not materially alter that fact. Sometimes one stops on a brushy mountain side or on the summit of a lofty pinnacle to stay the faintness of hunger with his jam or jelly sandwich 


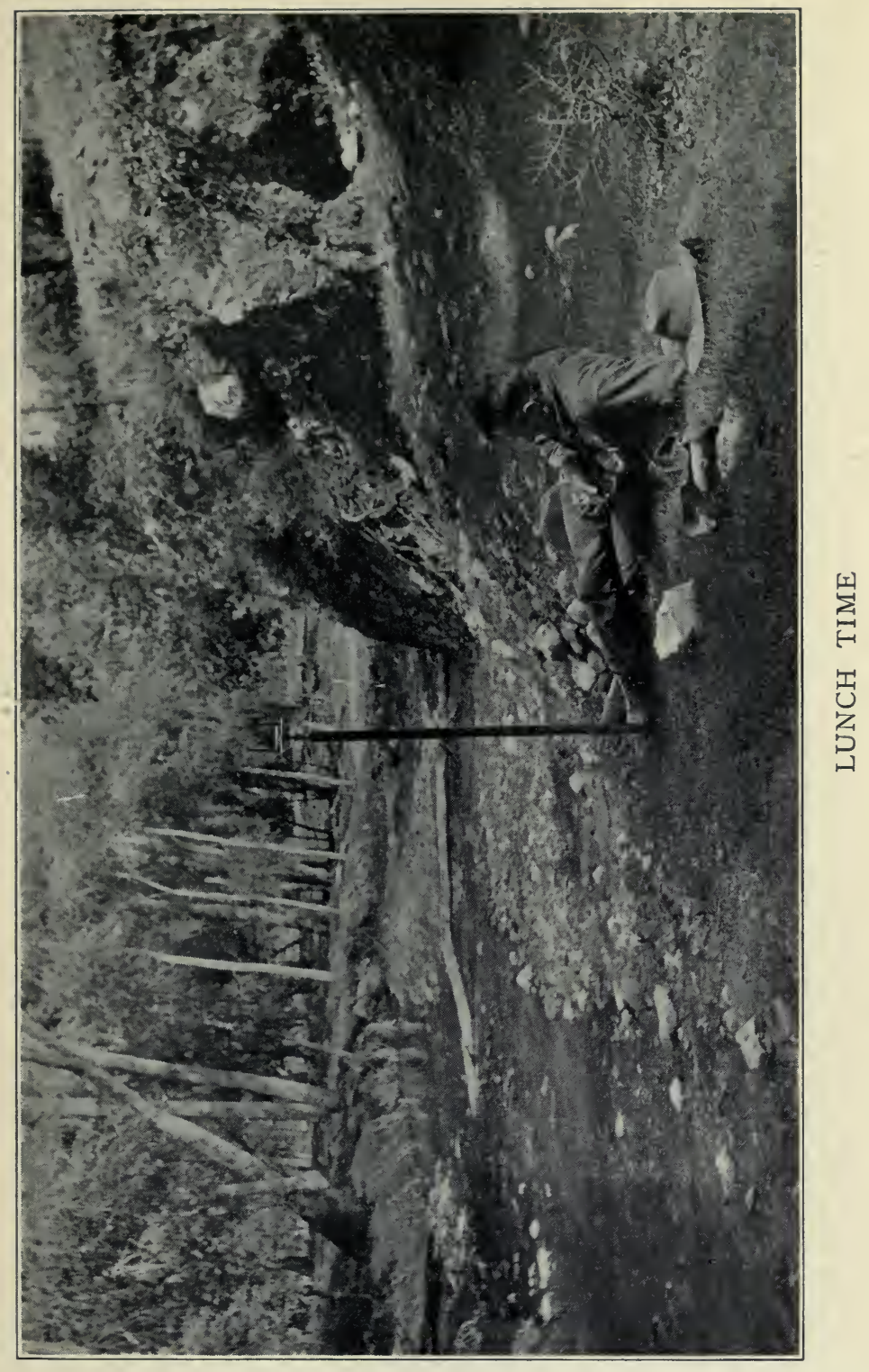



or bar of chocolate, for lunch is always light. But more often a seductive glade or shady brook will lure the cruiser to his hour of leisure. Oblivious then of the return run, the long miles to camp, he will sit ruminating pleasantly while the quiet minutes float away, soothed by the ancient peace of the forest, with only the murmuring of the stream or the chatter of a squirrel or the song of birds to keep his thoughts company.

When Frazer and I started back we found the westward journey much harder than the outward trip. It was a steady climb all the way. At noon the aneroid recorded an elevation of 8,200 . When we reached the baseline at half past four we found that we had ascended to a height of 9,100 feet, a climb of almost a quarter of a mile.

We checked in on station six. We were three chains too far north and a chain east of the station when we finished, fair pacing in rough country.

This checking in is always an interesting climax to the day's work. In unsurveyed land it is the only means a cruiser has of testing the accuracy of his pacing. Of course compensating errors may sometimes cause a man to come much nearer his station than the quality of his work warrants, but as a rule the practice is a fairly reliable criterion of the cruiser's proficiency in measuring distance.

We rested a short time before starting for camp. I felt full of energy and vigour, far fresher than in the morning, as if I could continue climbing moun- 
tains indefinitely. I spoke of this to Frazer, who said:

"That's a pretty good sign you've done enough. You're drawing on your nerves when you feel so light and airy. Every one gets that way after he's caught his second wind and is thoroughly warmed up. But don't let that fictitious feeling of strength fool you into overdoing. You can tell when you've gone far enough when you've had a little more experience in after effects."

If I had taken this advice to heart instead of letting it go in one ear and out of the other I might have avoided, a little later, a very unpleasant experience.

We got to camp at five o'clock, just in time for supper. Horace had not yet arrived. Nor did he show up till after seven, when we were thinking of sending out a search party for him. When he finally appeared he walked slowly and heavily, as if in the last stages of exhaustion.

"The altitude got me," he gasped, as he approached, "I've never been affected this way before."

He disappeared into his tent and groaned dismally at intervals.

Shortly afterward Frazer called me to one side. "Look at this," he exclaimed disgustedly, thrusting Horace's notebook into my hand. It was a fearful and wonderful creation that Wetherby offered as a map. Even I could see that the meaningless 
lines, wandering over the page in reckless fashion, produced nothing but what map men call "impossible country."

"It doesn't look very encouraging," I ventured.

"Encouraging!" snapped the chief, "it isn't worth a damn! I don't believe .Wetherby ever cruised before in his life. He only ran out three forties to-day and took twelve hours to do it! It's the limit!"

"Now that I think of it," I said, "he never really told us he'd done any actual timber work. Most of his stories were rather vague in that respect, if you remember."

"But he's got all the theories," shouted Frazer, thoroughly exasperated, "he can tell you all about it. He must have read up on the work before he came on. It makes me sick!"

"What are you going to do about it?" I asked, feeling vaguely that Frazer's confidences boded me no great good fortune.

"Well," he said, staring at me speculatively, "there's only one thing to do-you'll have to get busy and cruise regularly, as soon as you can learn enough about it. I can't trust Wetherby on that sort of work at all. I was going to put you on the baseline with the axe, but Wetherby gets the job. If he'll shed a part of that warehouse he carries around he ought to be able at least to blaze trees."

So next day, after a mild "bawling out," which Horace took with commendable meekness, he con- 


\section{THE LOG OF A TIMBER CRUISER}

sented to leave most of his excess weight in camp and shoulder an axe on the baseline. Here he showed to slightly better advantage. But the harassed expression which became habitual to the countenances of Wallace and Conway, and the ominous silence in which the baseline party filed into camp evening after evening, led us to suspect, as time wore on, that Wetherby's endeavours were not resulting in a perfection of accomplishment. 


\section{CHAPTER VI}

\section{MOAK'S ADVENTURE}

UNDER the constant coaching of Frazer I was gradually broken in to cruising. The work was fatiguing, particularly while one was growing accustomed to the change in altitude, but presently this wore off and I found that the daily run was becoming a fascinating experience. The constant change of scene, the magnificent views, the sense of exploration and the occasional hazards encountered effectually precluded the possibility of failing interest. Each new day brought forth its fresh adventures, so that the time passed, for the most part, easily and with the speed of thought.

There was, however, one phase of our work that had not seemed in prospect especially disagreeable, but which I found at first very difficult to get used to. This was the necessity under which each cruiser lay of working alone all day. Like most of us I had all my life been with, or at least near, other people every hour of the twenty-four. For weeks now I left my companions each morning with a distinct distaste for revelling in my own company till evening. There was an initial strangeness about finding oneself utterly and entirely alone in the for- 
est, miles from camp, out of sight and out of hearing of any human being, that was disgracefully like fear. The situation called forth qualities which a gregarious existence had well-nigh atrophied.

But Time, the master magician, calmed weakened nerves and developed latent forces till new habits were formed to fit the new circumstances. I felt, day by day, that I was gaining in self-dependence and poise. It was not necessary, after a while, to lean on the personality of another, to find contentment only in the physical presence of one's fellows.

Nay, more! Before the season ended, I found myself relying upon this daily spiritual bath of silence. A strange serenity grew within me-a quiet fostered by the constant close contact with nature. The eternal peace of the dim-aisled forest, wistful and brooding, lay like a chrism upon the soul. On some lonely peak, dominating a world outspread below, the spirit leapt forth and spread silver wings to meet the glory of those majestic mountain solitudes.

Despite the fact that use bred in us a disregard of the danger element in this individual cruising, a considerable hazard remained. A loosened rock or slippery tree trunk, an unseen crevice or crumbling ledge-any one of a hundred mischances-could easily cause an accident that might result seriously indeed before one could be found and cared for. An instance of just this sort of thing occurred before we had been out a week, and, though soon forgotten, 
gave some of us at the time considerable food for thought. Bob Moak, as I have said, had the best of the others of the party both in years and timber experience. He was, indeed, beginning to feel the strain of too long-continued and excessive effort. His hair was grey and scant; on his legs, from knee to ankle, bunches of varicose veins stood out deformingly. He was growing old at fifty, the day of his ultimate retirement not so many years away.

Though he would have fought at the suggestion, the old cruiser found it increasingly difficult to make his runs between dawn and dark. Some men, faced by this dilemma, would have "cut corners" - sat on some hill within sight of camp and "dreamed in" the map contours and the timber estimates. There have been instances, rare of course, of such a procedure.

But Bob was not that breed. Sometimes he came into camp as late as seven or eight at night, having worked since six in the morning; but his maps were always accurate, his estimates closer than those of any other man in the outfit. Always on such occasions, to save his pride, he made light of these late homecomings, saying, perhaps, with a pathetic attempt at jocularity, "Well, I shore overslept to-day. Took a nap right after lunch and never woke up till four o'clock. I'll have to git me an alarm clock $t$ ' take along, I reckon."

One night he failed to show up at all. A search was suggested late in the evening. 
"We might as well wait until morning now," decided Frazer; "I don't think there's anything to worry about. Bob's pretty careful. Probably he got caught by darkness and thought he'd better lay out over night. .With a fire it isn't much of a hardship."

So we postponed action till next day, when all of us but the baseline crowd set out early to hunt for the missing cruiser. Two parties were formed, one to follow Bob's outward line, east from his first station, the other to begin at the second station and run out the line along which he should have made his return run.

Frazer, Wallace and myself formed the second party, which proved the more successful of the two, for we found our man before we had gone a mile.

He was seated at the bottom of a rock slide, in a little canyon, smoking his pipe and gazing with immense disgust at his left leg, which was evidently out of commission.

Before we could question him in regard to his accident he removed the corncob pipe from his mouth and inquired truculently, "Got any whiskey?"

We produced the flask brought for just such an emergency and the injured man took a long drink, wiped his lips on the back of his hand and said:

"Reckon you all think I'm goin' into my second childhood, hey?"

"How did it happen?" queried Frazer.

"I just natchelly slipped," replied Moak. "I 


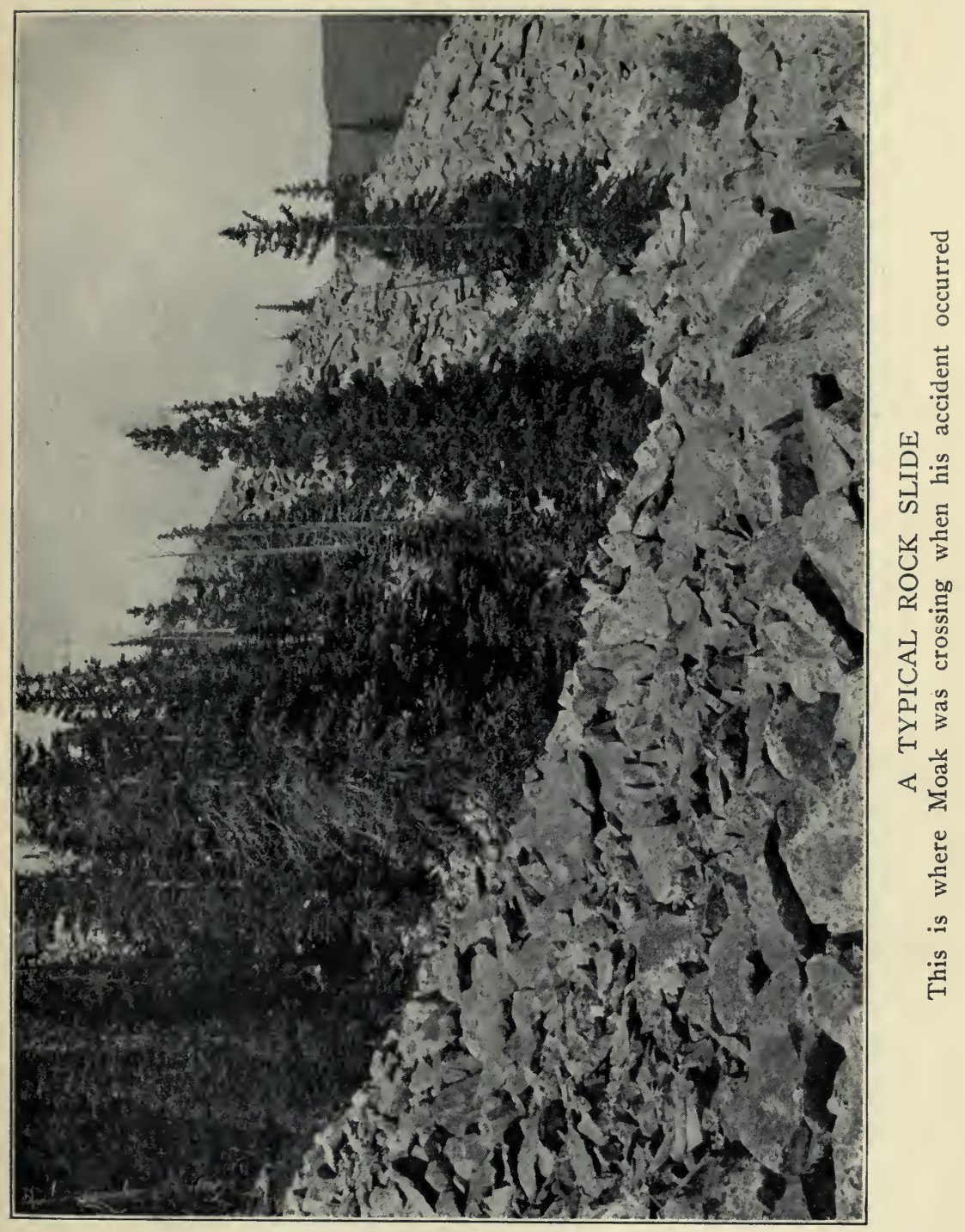



was crossing this here rock slide, up the side th' mountain a piece. She started down and I come with her. That there's about how it happened. When I picks myself out of the debriss I finds this leg like she is now. Reckon hit's strained a mite. So I set here an' waited for you all. Lucky I landed by a stream and had a plenty of tobacco with me, or I might-a-tried to crawl in, an' that wouldn't-a-been bueno."

We made a crutch for Bob after a little and by dint of much "boosting," and frequent rests, he managed to make camp in a couple of hours.

But it was a week or more before he could use his leg at all and some time longer before he cruised regularly again.

The incident brought home to us the necessity of constant watchfulness while alone in the hills. It didn't take a very great stretch of imagination to picture situations far worse than that into which Bob had been thrust. 


\section{CHAPTER VII}

\section{HORACE HAS AN ADVENTURE}

Horace, it was plain, however the others felt, highly approved of his new position on the baseline. He went at his task zestfully, bearing his axe aloft as if it had been a sceptre, and attacking trees and brush with a headlong fury that threatened annihilation to the forest. What mattered it that the swath he cleared through the woods was yards off the line, or if he at times dwelt so long upon the beautifying of a station monument that his companions were half a mile ahead before he finished. Horace was having a lovely time; that was sufficient.

We wouldn't have minded this attitude-those of us, that is, who were not working on the baselineif Horace had only kept his peculiar ideas to himself. But he displayed a sort of irritating air of superiority about camp which irked us considerably. Personal foibles which one can tolerate or dismiss with a laugh in town assume entirely different proportions in the woods. Conceit or egotism-any trait, in fact, which tends to infringe upon another's personality-acts with the cumulative force of dropping water. Before long the most adamantine selfcontrol is worn away in the process. 
There was no doubt that Horace, when it came to the sort of education derived from books, was, despite his youth, by far the most learned individual in the outfit. Our erudite friend's vocabulary asked no odds of "Noah Webster, his Dictionary." And: his familiarity with almost every branch of theoretical knowledge was really astonishing. As a result of these considerations, our talks around the camp fire threatened at first to develop into a series of monologues, with Wetherby taking on every occasion the speaking part.

Now, this was not at all according to Hoyle. In the woods the evening "pow-wow" is an ancient and well established institution. Immemorial custom prescribes the etiquette for such gatherings. Bert, Bob Moak and the packers, for example, never spoke except for the purpose of expressing an idea-and then briefly. While not conducive to fluent conversation, this practice usually enables each member of a party to have his say, with perhaps some time left to indulge in silent reflection. Then again, when a person is speaking, it is considered proper to allow him to finish without interruption, and even to pause a moment-a delicate tribute to the weight of his words-before replying.

Horace's methods were different. He talked for the sake of talking, for exercise, for effect, for the mere luxury of guiding a mellifluous flow of words into the night. Now and again, when out of breath, he paused, but if any one else attempted to voice an 


\section{THE LOG OF A TIMBER CRUISER}

idea or a sentiment he had no compunction whatever about breaking in and continuing the thread of his discourse.

This sort of thing was unpleasant. We suggested as much to Horace on various occasions, but without apparent effect. It was evident that if we were to enjoy our evenings at all some more radical action must be taken. But no one felt like starting a real fight. Quarrels in camp are about the last thing to be desired; resorted to, if at all, only in an extremity.

We felt, however, that in Horace's case there could be but one result. And true enough before many days the inevitable explosion occurred.

It came about this way. The constant wielding of a four pound axe had made of Horace a mighty trencherman. One evening, when he had twice made the round of the table for supplies, a thought struck him.

"It appears to me," he suggested to Frazer, "that Bert ought to wait on us and eat afterward. I've always been accustomed to being waited upon."

Frazer stopped short in the act of swallowing and stared at him to see if he were really in earnest.

Waiting on oneself at table is an invariable camp usage in the Southwest. The cook, indeed, as the most indispensable member of the party, holds a position a little superior to that of the chief. He is accorded marked consideration, treated with a special and particular brand of courtesy, for upon 


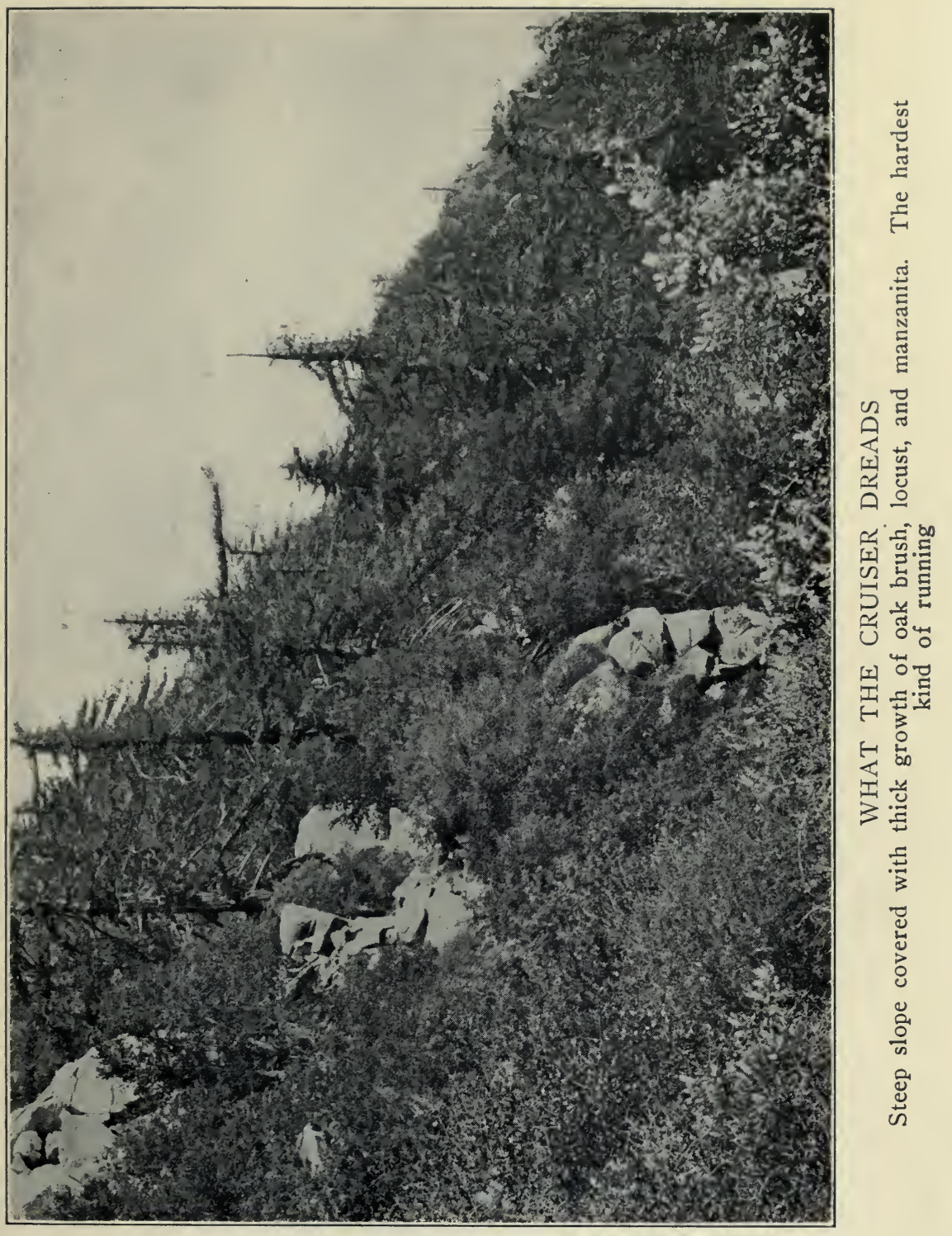



his humour depends always the happiness, often the health, of the whole party. Not the least of Bert's excellencies were his even temper and his cheerfulness, where so many of his professional brethren are moody, irritable or sulky. But he was not on this account the less inclined to uphold the dignity of his position, or to resent any attempt to "run it over him."

At Horace's heretical remark, therefore, our eyes turned fearfully to the cook, who was eating outside under a tree. He had not heard.

Then Conway, who particularly detested Horace, perhaps because he saw more of him than any, one else, did a malicious thing.

"Why don't you call Bert's attention to the oversight?" he suggested.

Every member of the circle held his breath, while Horace cleared his throat and called loftily:

"Oh, Bert!"

It was a plain summons to attend, but Bert, who had never admired Horace on general principles, merely grunted "Hunh?" and went on eating.

His interlocutor, a little nettled, thereupon commanded the cook in well chosen terms to arise forthwith and render him personal service in the matter of supplying "spuds, spoonvittles and frijoles." It took Bert a moment to resolve Horace's demand into its simple elements but when he did the rapidity of his actions made up for the tardiness of his mental processes. 
He leapt to his feet, seized a large soup ladle in one hand and advancing in front of Horace shook the other violently in his face.

"Ain't you able to wait on yourself, you big stiff?" he yelled in a frenzy of rage. "D'you take me for a — wet nurse, stannin' round feedin' you? I'm a great mind to knock the top of your head off, right now, and see what kind of a — fillin' you got in there."

Horace was nonplussed but rallied gallantly.

"Now see here, my man," he retorted, in a voice which he strove to render cold and steely, "have a care. A certain person died once for less than you have said!"

It was an awfully feeble bluff. Bert had called many more difficult in the games both of poker and of life. That "my man" phrase seemed to get him, too. Without a moment's hesitation he whacked Horace over the head with the ladle and followed the blow with as ably selected an assortment of profane insult and invective as I, at least, had ever heard. He charged him with ignorance, cowardice, immorality, arson, burglary, and obtaining money under false pretences. He referred to him directly and indirectly in so many different ways as a person unfit by birth, heredity, and education for association with honest men, that we blushed involuntarily for the offender and his presence in our midst.

Bert ceased only when exhausted. He glared 
fiercely at his wilted opponent. Horace was completely overwhelmed.

"Bert," he said at length, in a conciliatory tone, "I don't wish to have any trouble with you. But if you're going to fly up like this all the time I don't see how we can get along at all."

A general laugh ensued. The cook with an exclamation of disgust returned to his meal and the excitement died gradually away. 


\section{CHAPTER .VIII}

\section{AROUND THE FIRE}

THE last remnant of the awe Horace had at first inspired in us vanished with the "Episode of the Irate Cook." The unexpressed antagonism toward him, which had heretofore made his presence a constant irritant, disappeared. He was looked upon henceforth as a joke, tolerated on the condition of complete self-effacement, and squelched promptly and openly whenever he appeared in danger of forgetting this tacit arrangement.

As a result our nightly camp-fire confabs became much more enjoyable gatherings. Those intimate evenings stand out in memory as perhaps the pleasantest phase of the season's work.

Bygone camp-fire talks long past, how clearly, with what a warmth of detail, do they recur in recollection! I can see now, in my mind's eye, the very scene-the camp and the familiar faces and the fire burning lower and lower as the minutes pass.

Supper is finished, and a feeling of indolent peace and contentment steals over us with the lighting of pipes and the relaxation of tired limbs. Sitting on logs or stretched full length on the ground before the gleaming embers, we muse and talk; lazily arguing, spinning yarns, dreaming dreams. The faces 
flush or darken in the flickering light, there sounds the slow, gentle drawl of a reminiscent voice, the quick, hearty laughter at a point well made, a shaft well driven, the "puff-puff" of pipes, the slowly expelled smoke, hovering a moment, caught up in the column of the fire, languidly whirling and dissolving-incense to the spirit of fellowship, to the communion of minds and hearts.

Now old Bob Moak is talking, in his slow, deliberate way. WWith crude, broad strokes he pictures to us life as it was in his youth in the Northwest, among the lumber camps. Tales of wild men and wild lives with the sombre background of the fateful, illimitable forest. There is little eloquence, no attempt at theatricals or pose. Yet often one shudders involuntarily at the stark brutality of the incidents related and thrills with the pathos and heroism of some awkwardly developed story of naked cruelty, of magnanimity, of high courage.

Now Brown, the Texan, deplores the passing of the good old days when the whole West was a cattle range, when men lived largely and without restraint. In a high nasal voice he sings interminable cowboy ballads of "Black Jack Davy," of "Little Joe the Wrangler" and of others whose names and fates I have forgotten.

Now Frazer tells of the Forest Service, of his adventures in divers states, or of early struggles, not so many years ago, to enforce the Government's regulations on range and in forest. 
It was curious to note, as each one's individual attitude was revealed, how variously the facts and phenomena of life were interpreted. Bob and Bert and Brown were frankly materialists. A lifetime of labour, a constant struggle with men and circumstances, had dealt them the strength and limitations of their type. Courage, energy, self-reliance-these they possessed to an admirable degree. But beyond the world of obvious things, into the realm of the abstract or the spiritual, they had no conscious desire to penetrate. Of such matters they would not even argue, but remained indifferent if those subjects were broached, smilingly intrenched behind the seeming invulnerability of sense experience.

Horace, when permitted, gave us the conventional theories concerning any subject upon the tapis. But his ideas were so obviously second-hand, mere reproductions of the thoughts of others, that we made use of his knowledge more as a matter of reference or as a basis for argument than for any intrinsic value it might possess.

Wallace and Ewing seldom joined in the talk. Wallace was far more interested in a girl back East than in any entertainment we could offer. All his time outside working hours was devoted to a silent contemplation of her excellencies. iWe never looked for much from him, therefore, save a smiling, absent-minded acquiescence whenever directly appealed to.

Nor did Ewing enter extensively. into any of our 
discussions. His personality and attitude had piqued my curiosity more than once. Indeed, the non-committal youth with the sensitive features and the punctilious manners was a mystery to all. His past was unknown. His very name, rumour whispered, was assumed. But this is not uncommon in New Mexico, even in our effete generation and it is not considered the part of wisdom to remark upon any such eccentricity.

Since his departure from Hillsboro the packermusician had appeared distrait and ill at ease, at times dejected and at times restless and nervous. We thought perhaps that he felt uneasy without his violin, which, to our disappointment, he had insisted on leaving behind. Brown, however, maintained that his partner "missed his licker," and that it was only a question of days before he would be impelled by his inner craving to go "on one" again. 


\section{CHAPTER IX}

\section{EWING'S STORY}

As time passed speculation on our part concerning Ewing increased rather than diminished. The packer was without doubt a mystery. His face and bearing, his manner and his diction, certain telltale traits which stamped him as a man from another sphere of life-things incongruous with his assumed character and present occupation-whetted our curiosity and aroused an interest in his personality. which it was plain he by no means sought.

Twenty times a day I puzzled over the matter. What rash act, what error, or what misfortune, had brought Ewing to this pass: A burro puncher at sixty dollars per month, and prone to frequent intoxication?

That was it, perhaps-drink! But then drinking, until it becomes itself a disease, is so often merely. a symptom of some other, prior, deeper disturbance. Ewing did not strike one as a dipsomaniac. He seemed rather to make use of whiskey as a weapon against the virus of ennui or against his own more poisonous thoughts.

No, I decided, drink alone was not his bête noire. .What then? Often I itched to question him, but the 
reserve of the even-voiced, impassive packer was invariably impenetrable.

The chances are that I would have left the hills no more enlightened in regard to the subject of my: constant conjectures than when I began the season, had it not been for an accident which had the effect of at length unlocking the door of Ewing's confidence.

It happened this way. Coming in from a run one afternoon I encountered the packer, who was out hunting burros. We continued together, he riding ahead and I following on foot along the narrow trail. At one place the path wound along the edge of an ugly cliff, some two hundred feet high. Here, as luck would have it, we ran slap into a nest of yellow jackets.

This was bad enough in itself, but to make matters worse Ewing's horse, frantic with pain, reared, leaped, and pitched so violently that his rider, though! an expert horseman, had all he could do to keep astride the maddened animal. Twice they swung dangerously near the edge of the bluff and each time Ewing brought his mount around and with quirt and spur drove him from the abyss.

Again the ticklish manœuvre was repeated, the horse whirling, pivot-like, upon the very brink of the precipice. This time he swerved too close to the edge. As he turned, rearing, the soft rock beneath his feet crumbled and gave; his hind quarters slid slowly back and downward. I saw the haunches 
drop, the head, with staring, strained eyes, thrust forward, the forefeet drumming wildly. My eyes sought Ewing's face. It was calm and still as the rocks about. He seemed in no way altered by the extreme hazard of the moment, but sat leaning forward, slightly to one side, talking to the struggling horse beneath him.

"Easy, Bob," I heard him murmur, "don't get foolish! Easy, now, boy!"

Then I came out of my daze. I jumped forward, grabbed the roan's bridle and pulled with all my strength. A heave, a quick, fierce scramble, and horse and rider were safe. Ewing grinned cheerfully and patted his mount's neck.

"Much obliged," he nodded to me. "I sure thought we were goners that time."

I was somewhat exasperated.

"You must be crazy! You could have jumped at first. Why didn't you get off when you had a chance? You might just as well be there at the bottom as up here, except for a piece of good luck."

"Luck?" he laughed whimsically. "Well, perhaps it was. I've always had plenty of good luck -of that sort!"

The cynicism of his remark was unmistakable.

"If that's the way you look at it," I said, "you can drop off and be smashed next time. I wish I'd known you wanted to commit suicide!"

His singular humour left my companion abruptly. His voice grew grave, with a winning sincerity. 


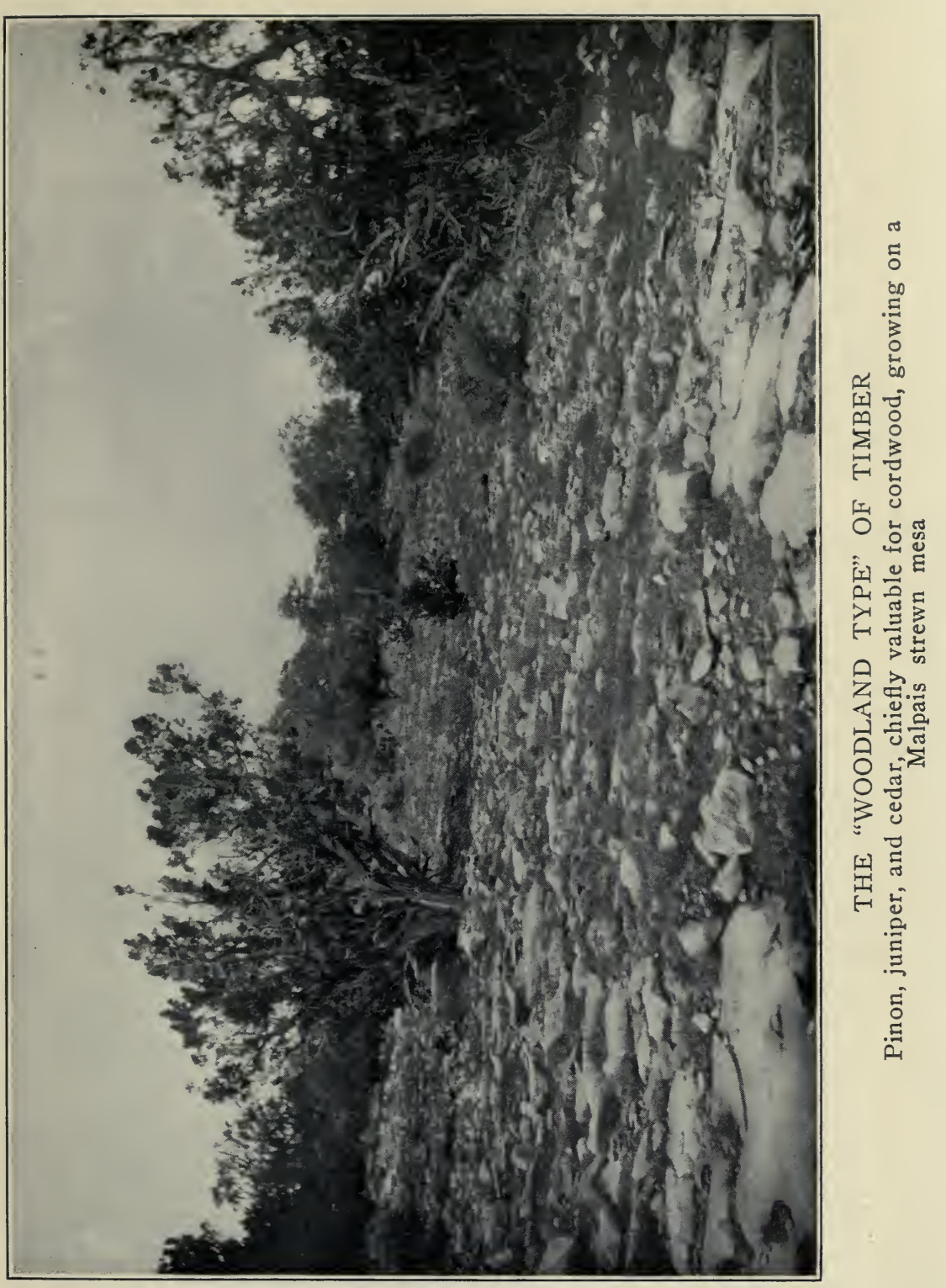



"Don't mind my foolishness, please!" he said. "Really, I'm more than grateful for what you did. You saved my life, I think. If there were any possible way I could show my gratitude I'd be only too glad to do so."

"You might tell me," I said, on the impulse of the moment, "what you meant just now by that remark about your luck?"

Ewing glanced at me sharply.

"That's a matter which I don't care to talk about."

"Oh, very well!" I answered, and that was all.

We were rather silent for the rest of the journey. to camp nor did either of us refer again to the topic so summarily dismissed.

But after supper, as I sat alone in front of my. tent, the violinist crossed over and flung himself on the ground beside me.

"I was a little short this afternoon," he began, "and I'm sorry. I spoke as I did. I hope you're not offended."

"Of course not!"

"Well, I'm glad of that. I often think I'm getting morbid on certain subjects. Things have happened that-well-I thought you were trying tothat you were getting curious."

"You were right," I interrupted. "I was curious about you, Ewing. To be frank, I can't see why a man of your obvious education and talents should 
be holding down the job you are. But my feeling was a little more than mere inquisitiveness. It's fairly evident that you must have had some hard luck, and I suppose I wanted to find out what the trouble was, and try to understand, if I could-and perhaps help, if that was possible. That was what was in my mind."

Ewing smoked in silence for a moment.

"Damn it!" he burst out, "there's no reason why. you shouldn't know. I'd like to tell you.".

He talked for a long time, unconscious of the passing moments. Bit by bit the snarl of his unhappy. history was untangled. There was no smooth narrative of events-just a halting, broken recital, stumbling in the darkness, through clenched teeth. 'A' story as old as the world, but new to each whose life it enters.

Ewing was not his real name. His family is wellknown. As a boy, the packer said, his talent for music was encouraged. He developed rapidly, and so long as his skill did not pass the limits of a mere accomplishment, the family was well content. But when they understood that he meant mastery of the violin to be his life's work objection arose. His father cajoled and threatened. Dilettantism the gentleman understood-it was a tenet of his creed. Professionalism was tabooed.

It ended in the boy's leaving home abruptly with the avowed purpose of making a living by his violin. 
In this he succeeded after a fashion, and as time passed he grew successful. A career seemed possible.

In the meantime he married. A mere girl, pretty, unsophisticated, affectionate but utterly ignorant of the responsibilities she was incurring-that was how. Ewing described his wife. They never got on together after the first flush faded. They quarrelled and made up and quarrelled again and then came, suddenly, the demolition of their house of cards.

"I blame myself," said my companion, "I blame myself more than Millie. She was used to attention. And I thought of nothing but my music-myself. One night I came in late-I'd played that night-and found she had gone. She left a notea few words only. She'd met some one, she said, who'd be kind to her.

"I took it pretty hard. I was half-mad, I think, for a time. I forgot my violin, my career, everything. I hit up the booze till I got to be a wreck. I began to inquire around and finally located the man my wife had run off with. He was a fellow named Donohue, a broncho buster with one of the Wild West outfits-sort of a tough proposition, from all accounts. But he must have cared for Milliethere wasn't any other reason for taking her away. "Finally I started out to find them. I'd drink a while, then work some; then whenever I found a clue, I'd follow after. They found out about it and Donohue deserted my wife. That made me glad: 
I was glad she suffered-poor little girl! . . . Well, I found her finally. .... She'd died the night before I reached her. I buried her and swore on her grave to find the blackguard that left her to die and kill him. ... And all the time I'd as good as murdered her myself!"

Ewing stopped and bit on his pipestem till the hard rubber snapped.

"Yes, I murdered her," he went on at length, in a husky whisper. "It came to me after a timea long, hard time. And now-now I can't tell her!" "Perhaps, in some other life-"

"Oh, I've thought of that," broke in the packer. "But some other life isn't this one-and it's in this one I killed her, with my damned selfishness. No! I've got to take my medicine, as she took hers and, by God, as Donohue'll take his when I get him!"

He seemed on the verge of a breakdown.

"Have you had any trace of Donohue?" I asked.

"He's in the Rio Grande Valley somewhere, right now," said Ewing, more quietly. "I don't know where, but he's hiding somewhere. He knows I'll get him. I was broke when this job came along, so I took it for a grub stake. .When I'm through. . . ."

He shook himself and rose abruptly, and his old manner returned.

"It's good of you to listen to all this," he said, " and it's helped me. Some times I've thought I'd' go insane. It's helped a whole lot just telling some one about it. I think I'll turn in."' 
We shook hands and parted for the night. And above us the wise, impassive stars gazed down as they did in the beginning and smiled with shining faces on the world below, impartially and unaccusingly. 


\section{CHAPTER X}

\section{A RECORD RUN}

The first camp at Sawyer's Peak sheltered us for some little time. We ran the baseline five miles north, cruising both east and west, then started again at camp and began to work south. We finished the Percha Creek watershed in a week, then moved three miles to the head of Trujillo Canyon, which runs in a southeasterly direction to the Rio Grande. Then south again two miles to Tierra Blanca, an exceptionally rough watershed also draining to the east.

I had been cruising steadily during this time, since that first run with Frazer, and was quite elated at the comparative ease with which I picked up the knack of pacing and plotting contours. I began to feel myself a seasoned man. No run was too difficult to undertake, no stretch of country impossible to traverse. This state of mind was of course a result of inexperience. And it was one day thoroughly. eradicated by an adventure which I recall even now with particular distaste.

One morning we started east from the baseline with instructions to run as far as the timber extended-that is, if we were able. 
The country was typical of the locality-rough, brushy and precipitous. Four to six forties out made a good average run.

As I left for my station Frazer called jokingly:

"Looks like you've got the post of honour to-day! You ought to get some mean going. Get out as far as you can, but don't overdo it!"

In my cocky mood this sounded very much like a challenge to performance and I started out with the firm intention of reaching the edge of timber if it extended ten miles. As a matter of fact it was three miles-twelve forties-before the pine petered out and the woodland type began to appear. To get that far I had dropped from 9,000 to 6,800 feet altitude, and crossed several exceedingly steep ridges which buunded the side canyons draining into Tierra Blanca Canyon some thirty chains north.

When I finally surmounted the last ridge and saw nothing beyond but scrubby piñon and juniper, it was just noon. The sun seemed hotter than usual. As I glanced at the aneroid and saw the three thousand foot change in elevation the reason for the increase of temperature was evident. My canteen was dry and I decided to postpone lunch till later, on the chance of striking water coming back. I felt comparatively fresh, so that while the prospect of the uphill climb home was not at all attractive, I had no special misgivings as I began the return trip.

The first mile in was about as exasperating work as could be imagined. I was running high up on 
the ridges, near the top of the divide between Tierra Blanca and the watershed directly south. The eastern slopes, up which I made slow and painful headway, were thickly covered with oak brush and manzanita. In the knee-high grass grew cactus and Mexican locust, the thorns of which rip through clothes and flesh like tiny daggers.

It was necessary actually to fight one's way through this mess, step by step. No care, however great, served to avoid the brush and thorns. The sun poured steadily down into the tangle. It seemed to grow hotter and fiercer, moment by moment. Perspiration, a dirty red from dust and blood, ran in streams down my face and limbs. I began to suffer from thirst. My mouth and throat were like brick dust.

Pebbles held in the mouth and chewing tobacco, recommended under such conditions, did not relieve these sensations in the slightest degree.

I gradually became possessed of a dry rage, unreasoning and vindictive, with only the single idea left to hold my line and reach the top of the next ridge. Slipping, sliding, cursing, tearing the brush aside with my hands, butting into it head first, falling, rising, crawling on all fours, I advanced slowly, foot by foot, until at length I broke through a screen of branches and emerged to the comparative open of the summit. I dropped to the ground and lay there, completely done.

When I thought of the two miles and more remain- 


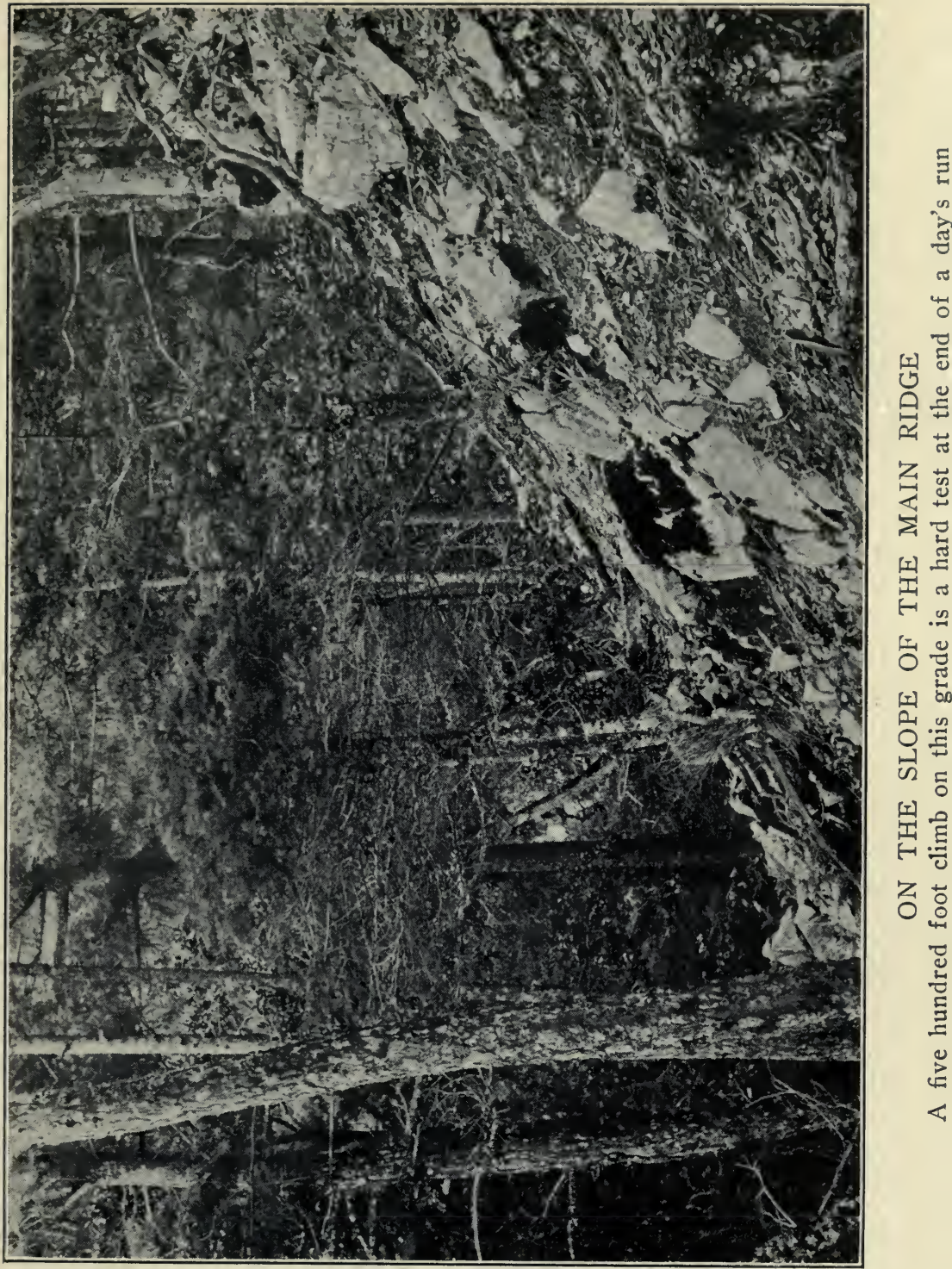



ing my spirits sank. But at length I got my wind again and started out more carefully than at first, realising the folly of fighting the brush. The line led downhill for a few hundred feet, a fairly easy descent, across a dry creek bed and up the side of the next ridge, higher by two hundred feet than the last. It was a repetition of the previous climb, but without leaving my line for more than a few yards I took my time and picked the easiest route through the dense cover. This saved clothing and person somewhat but the strain of the continued effort, the faintness from lack of food, and the effects of thirst, which was now a nightmare, were having an effect. At increasingly short intervals I was forced to stop and rest. At first a brief halt was sufficient. But as time went on each breathing spell was longer, each start more difficult. I felt absurdly weak and dizzy. My heart pounded violently on the least movement. And underneath all other discomforts, surrounding and overshadowing all, was the craving for water.

I had considered the possibility of offsetting to Tierra Blanca. But I knew that this like most of the other canyons was dry now, and the chances of running on a spring were slim indeed. Besides, I felt that if I left my line and went down into the main canyon I would never be able to return and finish the run. And this I was determined, if possible, to do.

So I kept on, making less and less headway, struggling against exhaustion, against the reaction of the 
heat, and against over-exertion. I recall very little of the last mile. I remember vaguely reaching the foot of the final ascent-the main ridge, along which the baseline ran. Five hundred feet high towered the tree clad slopes, steep and formidable. I sighted my compass, took a few steps upward, and for the first time in my life fell in a dead faint.

I must have been out of my head for a time. The first thing I remember after my strength gave way was coming out of a daze some distance from the place where I had dropped unconscious. I was stretched flat on the ground sucking water out of holes the hoof-prints of range cattle had made in the sandy bed of Tierra Blanca creek.

I sat up and looked around. It was dark, with the stars shining cheerfully overhead. The air was distinctly cold and I reflected dully that I had better make a fire and prepare to spend the night where I was. But I did not move. A feeling of utter relief and peace lay upon me. To stop there and rest, for days and days, was the only desire I had. The little water I had managed to swallow, seep from some hidden spring, must have been responsible for these sensations.

Doubtless I would have yielded completely to lethargy had not a pistol shot some distance away startled me into a more energetic frame of mind. I drew my automatic and answered. Soon I heard a second shot and later still another sounded. They were coming nearer and nearer. At intervals I fired 
in answer to the signals. Presently Brown's long, shrill scream came echoing through the woods, and a few moments afterward he and Frazer reached me. They carried water and a flask of whiskey. I took all of each that was good for me.

Then I briefly and rather shamefacedly related the day's chapter of incidents.

"I'm sure glad nothing more serious happened," remarked Frazer shortly, when I had finished. "We thought perhaps you might have been hurt. For Heaven's sake don't get ambitious again. We can't afford to lose any cruisers at this stage of the game."

Another swallow of water and a last pull at the flask and I made shift to climb the ridge, by easy stages. We reached camp at ten o'clock.

I fell asleep almost instantly, lay like a log till morning and awoke able to do a light day's work. But it was some time before I regained my normal self-conceit, and still longer before the camp grew tired of guying me on my "record run." 


\section{CHAPTER XI}

\section{PHOBY-CATS}

Ir was at Tierra Blanca that we had our first experience with "varmints." For some time after we set out those of us who were green had felt a little nervous at night before falling asleep. The sensation wore off before long, but while it lasted it gave us some unpleasant moments. The sight of ants, centipedes or spiders disporting themselves on one's bed, the pattering feet of rats and chipmunks on the tent roof, the thought of possible nocturnal incursions of skunks, bob cats, snakes or tarantulasthese things were beautifully. calculated to render one's slumbers uneasy.

Such a state of mind, unerringly perceived by the seasoned woodsmen of the party, was played upon skilfully, for their diversion. Hair stiffening stories were told of the danger of vicions midnight marauders and dark hints dropped, from time to time, of the perils of our situation.

"This here's a mighty likely place for vinegarons," Bert would aver, sepulchrally, as we pitched camp. "Them little ole things is shore pizen, too. I knowed a feller onct-" and we would get the blood chilling yarn delivered in the cook's best manner. 
Or Brown would come in some evening with a long face and state, confidentially, "I seen the biggest b'ar track to-night I seen in a month of years. Seems like them b'ars is gittin' mighty bold here'bouts lately. I have hearn tell of one comin' plumb into camp and jumpin' onto a feller. But I don't hardly think they'd be likely to this time of year. What do you reckon, Bert?"

"Dunno," Bert would reply, in a hushed voice, shaking his head dubiously; "a feller can't never tell nothin' 'bout them critters. They mought take it into their heads to do anathin'."

As a matter of fact there was little danger from anything but skunks. But of these pests even cowpunchers and woodsmen, careless in the presence of most perils, stand in deadly fear. For the skunk will sometimes attack a sleeping camper and bite any exposed part, usually the face, before the victim is aware of his approach. The danger lies, according to local tradition, in the fact that the animals are occasionally hydrophobic, especially during the dry season. Instances of a horrible death resulting from their attacks are by no means rare. And so prevalent in consequence is the dread of them and so general the belief in their power to infect one who is bitten, that the small spotted skunk is invariably known locally as the "phoby-cat."

Brown and Bert were careful to hide their fear of skunks as long as they could, but it was revealed during our Tierra Blanca sojourn in a rather dra- 
matic and, for the rest of us, highly diverting manner.

We were sitting around the fire on the first evening in our new camp. Brown, with a wink at Bert, drawled:

"Seems to me I smell somp'thin' pow'ful like a phoby-cat. Don't you all notice it?"

Now as a matter of fact, though the inquiry was made with no expectation of an affirmative answer, at this precise moment a penetrating and unpleasant odour recognisable at once as emanating from the animal referred to and doubtless the result of our dogs' researches nearby, did indeed pervade the air about us.

Brown chuckled gleefully. His assault upon our nerves was to be reinforced by a dash of extremely realistic atmosphere.

"Reminds me of the night," he said, "when ole Sam Saffel got skunk-bit."

"That was in ninety-five, wa'nt it?" asked Bert, his faithful coadjutor.

"Bout then," said Brown judicially. "Let's see, there was Slim Hitchcock, Hinray Betts, Sam an' me. We was range-brandin' calves for the G. O. S. outfit over on Bear Creek.

"Come jest such an evenin'. as this here, and we all smelt skunk right after supper. Ole Sam was pow'ful scairt of skunks and he wanted we should take turns settin' up all night watchin' for 'em. But we laughs him plumb out of the notion 'twell bimeby. 


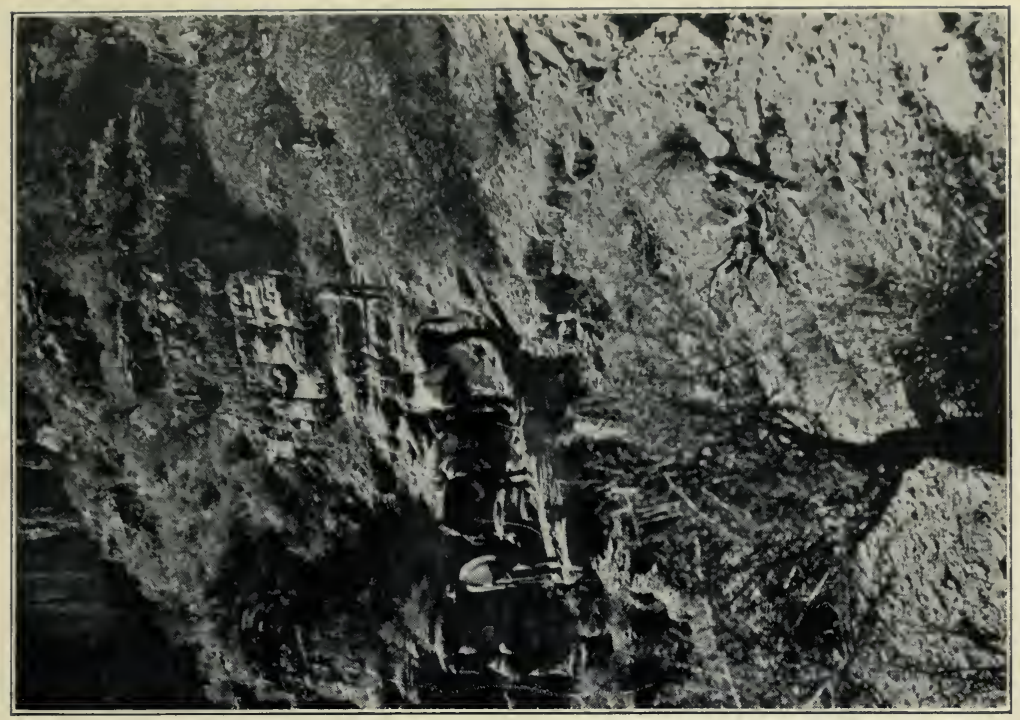

这

s

(1)

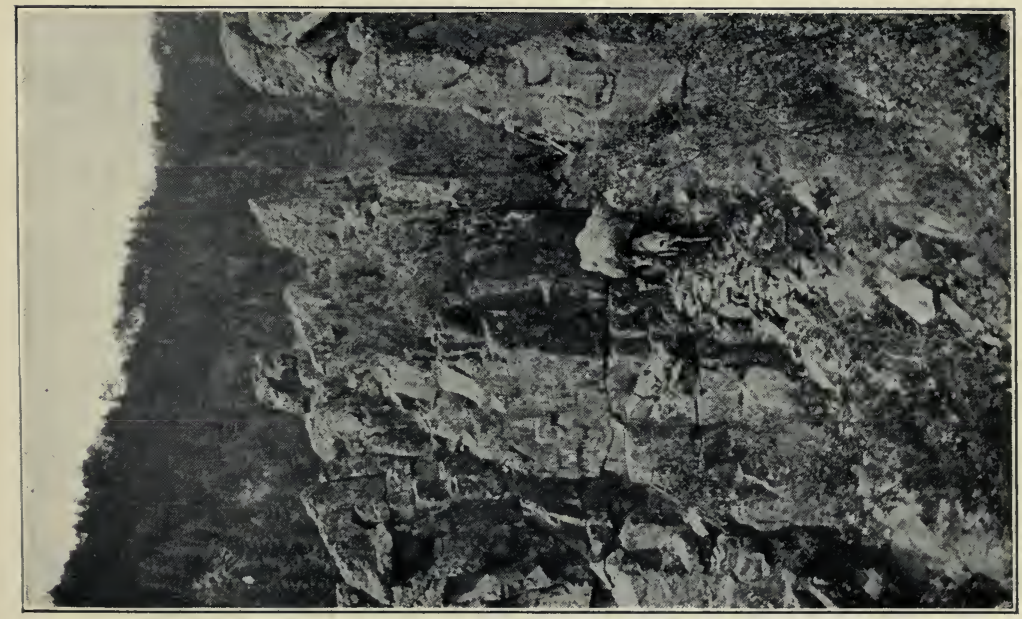

告

\begin{tabular}{l}
4 \\
4 \\
\hline \\
\hline
\end{tabular} 

he give in and we crawled into bed and went to sleep.

"Didn't seem like mor'n five minutes afterward when we was woke up by the worst screechin' you ever hear. Ole Sam was settin' up in bed a-pullin' a skunk offen one ear. An' he was shore hollerin' lust-ly, as the feller says.

"Well, we kilt th' skunk an' didn't think no more about it t'well about a week later when we wuz hustlin' for town, havin' run might' nigh out of chuck. All on a sudden Ole Sam took convulsions and begin foamin' at th' mouth and we had to tie him down out thar in th' woods an' leave him, seein' as we couldn't very well take him along the way he was actin' up. We shore hated to drop th' ole feller," lamented the narrator, sadly, "but they wa'nt nothin' else to do.",

"Good Lord," cried Conway, "you didn't leave him to die that way, did you?"

"Naw," returned Brown, more dolefully than before, "we shot him afore we left."

"Tom Mestic got off luckier than Ole Sam," remarked the cook, after a short general silence, "the time he got bit."

"Don't seem's if I remember that," Brown came back.

"T 'Twas a little before Sam died. We was camped on the Seco. Tom an' me and Sam Morgan and Bill Sanders didn't know there was any phoby-cats in the neighbourhood till one night a skunk came into camp an' bit Tom plumb through the upper lip 
whilst he was sleeping. A-course he woke up right away, an' so did the rest of us. We wa'nt right sure th' skunk was a phoby-cat, seein' he got away, but to be on the safe side Bill an' me helt Tom an' Sam Morgan run a piece of red-hot bailin' wire thro' the holes in his lip so's to clean 'em out good. He ain't never had no trouble sence, only havin' t'wear a moustache-which don't hardly compare for hard luck with bein' dead."

This tale provoked argument, but Bert stoutly maintained its truth. Indeed, I have since had occasion to verify it.

While we talked, the penetrating, unpleasant odour that was before barely noticeable had become stronger. And this or something else woke me several times during the early part of the night. I was just dozing off after one of these wakeful spells when a most extraordinary rumpus outside brought me bolt upright and wide awake. Slipping on a pair of moccasins I ran over to Brown's tent, from which issued agonised cries, and was just in time to meet the packer hastily emerging.

I thought for a moment he had lost his mind. He seemed as far as I could make out to be trying with his right arm to pull the left from its socket, proclaiming meanwhile in ear splitting tones that he was "skunk-bit."

Frazer, Conway, Wallace and Wetherby appeared, Horace in a high state of excitement, waving his two Colts menacingly. But no skunk was to be seen. 
"Whereabouts is he? Which way did he go?" we shouted.

Brown, instead of answering, rubbed his eyes and looked sheepishly about him. He seemed to be coming slowly out of a daze.

"Doggone it," he ejaculated, at last, "I reckon there wan't none. This yere arm of mine done gone to sleep an' when I woke up dreamin' trouble and felt it lyin' under me and smelt that there skunk I shore thought my arm was bit."

We had "the edge" on Brown and were not loath to take advantage of it. There was considerable laughter at the packer's expense, in the midst of which he retreated into his tent.

Then we began to wonder where Bert and Moak were. We found them deep in their blankets with tarps pulled over their heads. They pretended to be asleep but the pretence was hardly convincing.

The real skunk, whose proximity no one doubted, did not annoy us that night but a few evenings thereafter he entered the camp precincts, doubtless to forage at the garbage hole, and was oddly enough chased into Brown's tent by one of the dogs and. killed upon the packer's bed. For some days thereafter both bed and dog were deservedly unpopular.

As Frazer put it, after suffering for a day: " I've heard of animals dying game; but that skunk died 'gamier' than anything I ever knew of."'

We finally forgave him-Frazer, that is! 


\section{CHAPTER XII}

\section{ROUNDING THE SOUTH END}

From Tierra Blanca we moved to Donahue Canyon, our southernmost camping place, and a few miles only from the Gila Forest boundary line. The range dropped off quite sharply here. We were but little higher, in fact, than we had been at Kingston. No tents were erected. We had stopped near an old cabin which would serve for shelter in case an unexpected storm came up, for the rainy season was due to start at any time now.

The cabin belonged to a miner named McGee whose present habitation was but a short distance off. He came over after supper, ostensibly to borrow coffee, in reality to talk.

"I'm glad to meet a bunch of guv'ment men," he announced, after introducing himself. "Becuz I'm for ye. There's them that's agin' the guv'ment an' the National Forests an' the rangers, but ye'll usually find it's becuz they can't inflooence ye to some devilment, like they maybe could some private pa-arty. Thin they raise a howl about conservation bein' the ruination of th' country, starvin' out the poor man an' drivin' capital away. That's humour for ye. Drivin' poor timid capital away; capital that's so scairt of takin' a chance it'll only commit 


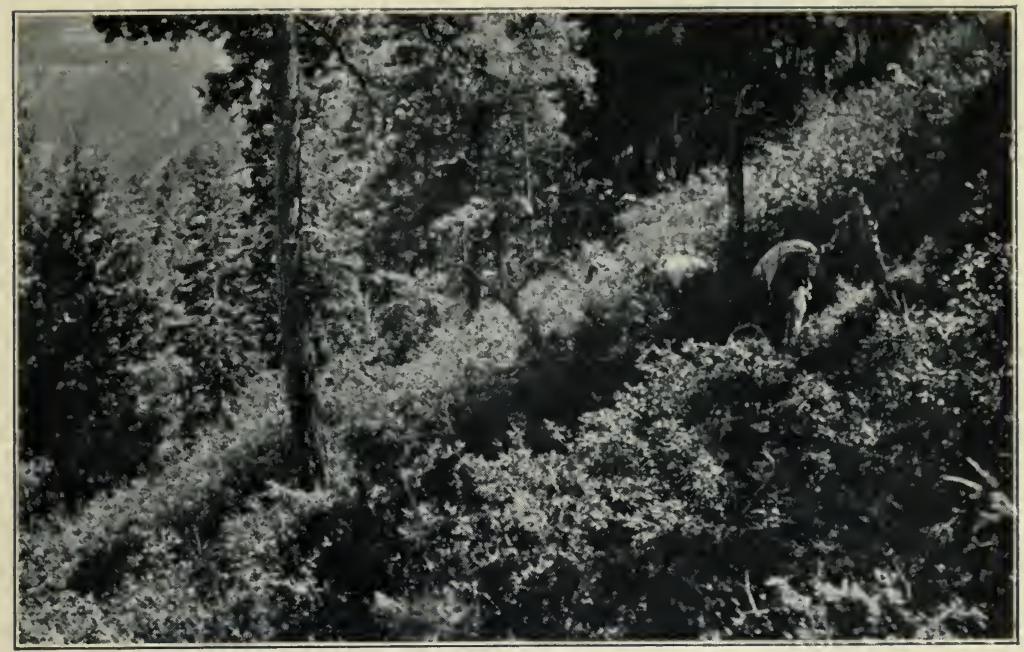

In moving from Donahue's Canyon we drove the burros along an almost invisible trail

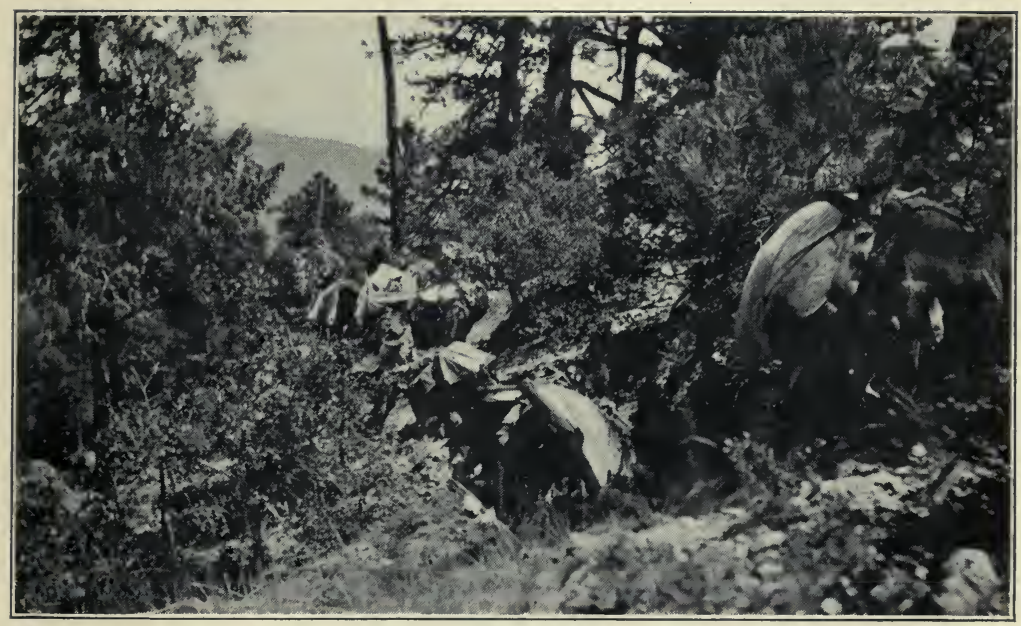

A halt for repairs. One of the packs slipped here and held up the whole procession 

every crime in th' calendar to make three per cent intrust; capital, that don't care enny more for a fightin' chance to earn a dividend than I do for me lim's. No, no, byes! Capital'll go anywhere there's a chanct to make money-a little thing like guv'ment regulation won't drive capital away. But grafters, that's another thing. Them that comes here like a man would go to a bank an' say to the President: 'Here, you, I wanna be a director an' get let in on a couple of hundred per cent profit for me money, or I won't play,'-them fellers is scairt away jest like the bank would scare them. What 'capital' like that is lookin' for is a roulette wheel-an' it wants to own the wheel.

"An' as fer the poor man," McGee went on, "he's got a whole lot more chance on the National Forest to-day than he has offen' it. Haven't I got twenty and more mining claims here meself-an' no trouble in gettin' any of thim. 'The rules is so an' so,' says the Supervisor, 'the forests is to use, so long as not abused,' says he, 'an first come first served,' he says. If ye' want to build a road, or use water power, or let y'r sheep or cattle run on th' forest, ye git y'r permit an' pay y'r fee, an' there y' are. If ye wanta take out a homestead claim, or a mining claim, or cut wood or run a sawmill the way is simple to folley. There's no running to a town meetin' or a crooked offishul or a politician to make it easy for ye to do somethin' ye ought not to be allowed to do -for a consideration. 'Ye don't haf' to bother with 
th' politicians; that's what makes thim mad. An' that's the reason they're hollerin' their heads off about the turrible guv'ment regulations of Forests an' how lovely t'would be if the states had thim. T'would so-but fer the politicians and their fren's, not fer you and me.

"An' much as they holler, an' much as they'd like to git somethin' on the Forest Service, ye never heard one av thim yet cha-a-rge any favrytismye never heard thim say that any offishul of the service give one man anathin' ahead of another, unless he had a right to ut."

We applauded McGee's speech heartily. Nor did it take us by surprise. For among the actual users of the Forest, the men earning their living by working for it, the general feeling now is that the Forest Service administration is fair and just and in general conducive of much better conditions for the small man than the old laissez faire policy of competition and waste on range and in forest could ever be; that it would be a calamity to return to that condition and that it would be a régime only a little, if any, less disastrous if the forests were to be put into the control of the various states. For that would mean, in too many cases, into the hands of the state bosses.

Before we left this camp the old miner bestowed upon us a wealth of facts regarding the mineral resources of the Black Range. He was optimistic as to future prospects. He showed us samples of ore that looked good, and seemed to think that it would 
be only a brief period before he could interest moneyed men in his schemes for development.

From Donahue Creek we turned westward and made a move of six miles across the divide to Gallinas Creek, one of the larger streams flowing southwest into the Mimbres.

On this move we gained some valuable experience in burro punching. The packers had been obliged to make a trip to Hillsboro with part of the outfit and were not yet returned. So the rest of us wrangled the "wild asses," as Brown called them, on moving day, and after a little longer time than usual got them packed and under way.

Bob Moak, Frazer and Bert did most of the actual work. The rest of us, I'm afraid, were more in the way than otherwise at this time, though before the season ended wo became fairly proficient in the art of packing.

Horace amused us all by endeavouring to maintain an attitude of thorough conversance with what was going on, while continually falling into laughable blunders. One of his mishaps will live. He was busily engaged in helping to pack old Red, unconscious of the fact that Methusalum's tie rope had become accidentally wrapped about his ankle. A few seconds later he was jerked flat on his back by an unexpected movement on Methusalum's part and had to borrow one of the packer's horses for the trip. I forget what he called his trouble but, as Ewing said, the name deserved support. 
For the first few miles of our trip we had good going. The route lay along an excellent road cut in the side of the mountain by an old mining concern whose property has for years now been idle. We were congratulating ourselves on this good luck when the highway stopped abruptly at El Centro, a group of empty shacks marking the site of the former mining camp, and an almost invisible trail led us from there through two miles of thick oak brush and locust.

Our untutored pack animals immediately scattered in all directions like a covey of quail. As soon as one of them felt that he was out of sight he would stop and stand silent and motionless until some one of us found him and drove him back into line.

It meant a strenuous afternoon of rushing hither and thither in the tough, scarcely penetrable cover, looking for laggards, bringing up the recalcitrant, counting the outfit over every few minutes and, if they could not all be accounted for, starting out to search once more.

But, like all things, our task came finally to an end and we made our first Gallinas camp at sundown, with tired bodies and frayed feelings but with none missing from the roll of jackasses.

We remained at this camp several days, making long runs to the west and shorter ones eastward to abut on our work of the preceding weeks.

Our next move but one took us to the head of Gallinas Creek, near the summit of Hillsboro Peak. 

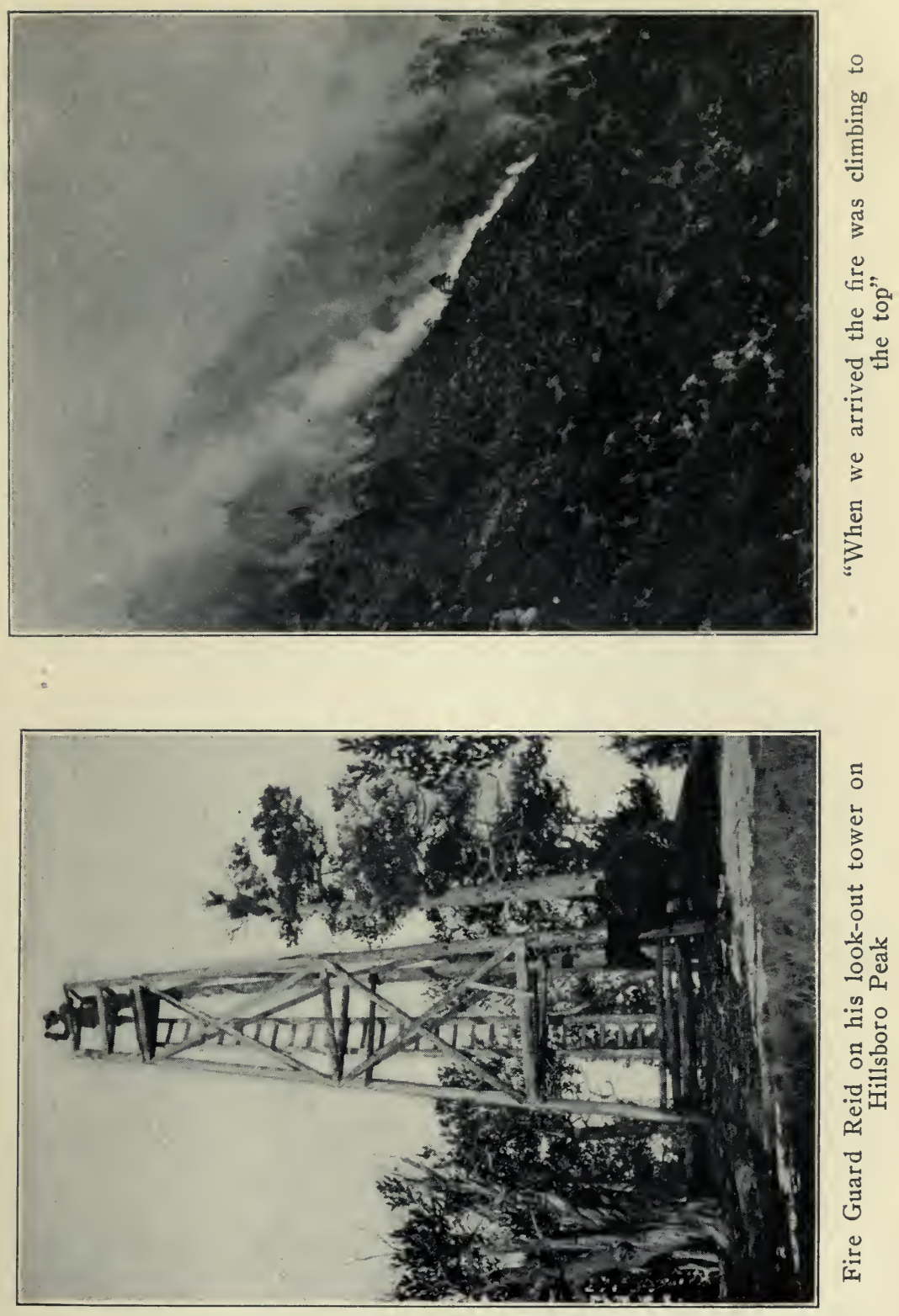

This mountain rises to a height of over 10,000 feet, and with the exception of Yellowjacket Peak, near the northern boundary, is the highest point along: the range.

We were camped by Hillsboro Lake, a pretty pond set in a most picturesque growth of aspen. The camp was on a fire patrol trail along the main divide and we were visited twice a day while there by a fire guard on his way to and from the lookout station on top of the Peak.

During his visits this guard, a young fellow from Hillsboro named Reid, explained to those of us who were unfamiliar with it the Gila fire plan, of particular interest to us at this time inasmuch as we were liable to be called upon to assist in fighting a fire any time it got beyond the control of the regular fire force.

The system adopted by the Supervisor is ingenious and effective. It contemplates, first of all, a special force for the forest during the fire season (approximately from May 1 to July 1) consisting of three patrol chiefs in charge of fire districts and fifteen beat-patrolmen.

The Black Range, designated as Fire District One, is divided into six patrol divisions, each one in charge of a fire guard. The lookouts, one to a division, are on Sawyer's Peak, Hillsboro Peak, Yellowjacket Peak, Mimbres Head, Sheep Creek Peak and Terry Peak. These lookouts are visited at least once a day; in times of particular danger a 
guard camps continually at the more important towers.

Every station is provided, in addition to fire tools, with a compass, a field glass, a fire map and a standard protractor. Also it is connected by telephone with the Supervisor's office in Silver City.

When the fire guard spots a fire from the lookout peak he at once reads its angle of direction from the protractor. This he telephones to the Supervisor, together with any other facts such as the apparent size and character of the fire that he thinks important. As soon as two or three direction readings from different lookouts are received at Silver City, the Supervisor proceeds to locate the fire by means of the large fire map there. Every lookout station shown on the map has a thread of silk attached to it by one end. This thread is drawn across the map in the exact direction indicated by the angle sent in, and the precise point at which two or more threads cross indicates the location of the fire reported.

All arrangements for attacking the fire or fires may thus be made at headquarters almost as soon as they are discovered in the field, and a force of men sent at once, if necessary, by the best and quickest route to the scene of action.

So efficacious is this system that no fire on the Gila, Reid told us, had obtained over twenty-four hours' headway, before being discovered, since the fire plan was put in force. We were profoundly: 


\section{ROUNDING THE SOUTH END}

grateful for this fact and slept the better for a knowledge of it. Had we been able to forecast the immediate future we would have rested less easily, perhaps, in our tents by Hillsboro Lake. 


\section{CHAPTER XIII}

\section{FIRE}

ALL went well until Saturday-the end of the first week in our Hillsboro camp-when trouble broke from a clear sky. We had finished a rather hard day's work and were in the act of sitting down to supper when the drumming of horse's hoofs came to our ears. A moment later Reid, the fire guard, approached at a gallop and drew up just long enough to shout:

"Fire's broke out on the north slope of Hillsboro Peak. It's got away from me. I've phoned for men but they can't get here till morning, so you fellows'll have to come up to-night. There's plenty of axes, hoes and gunny sacks, but we'll need water. I'm going back to do what I can till you get there. Don't lose any time-every minute now may save hours of work later!"

Then, whirling about, he galloped off up the trail.

The hasty summons of the guard materially altered our plans for the evening. Instead of a leisurely supper and a comfortable loaf about the fire, with bed hovering pleasantly in the background, we saw before us a long night of heart-breaking toil by the red light of flames, a night such as haunts the 


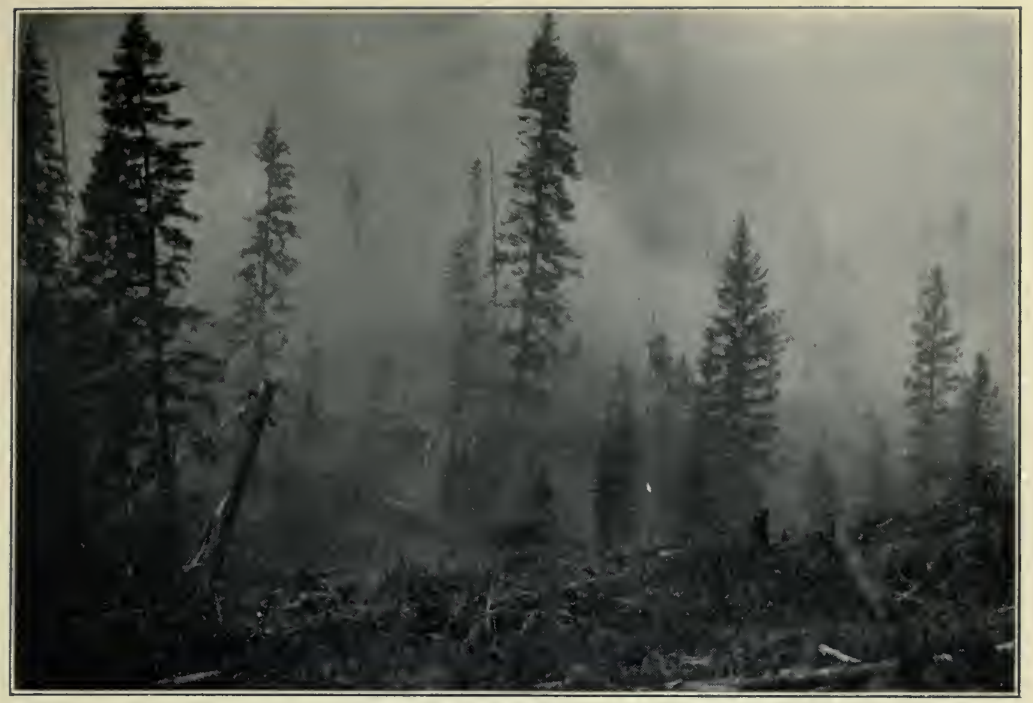

THE APPROACH OF THE FIRE

* As seen at a distance, smoke from the burning brush filled the air. Nothing else for a time could be seen

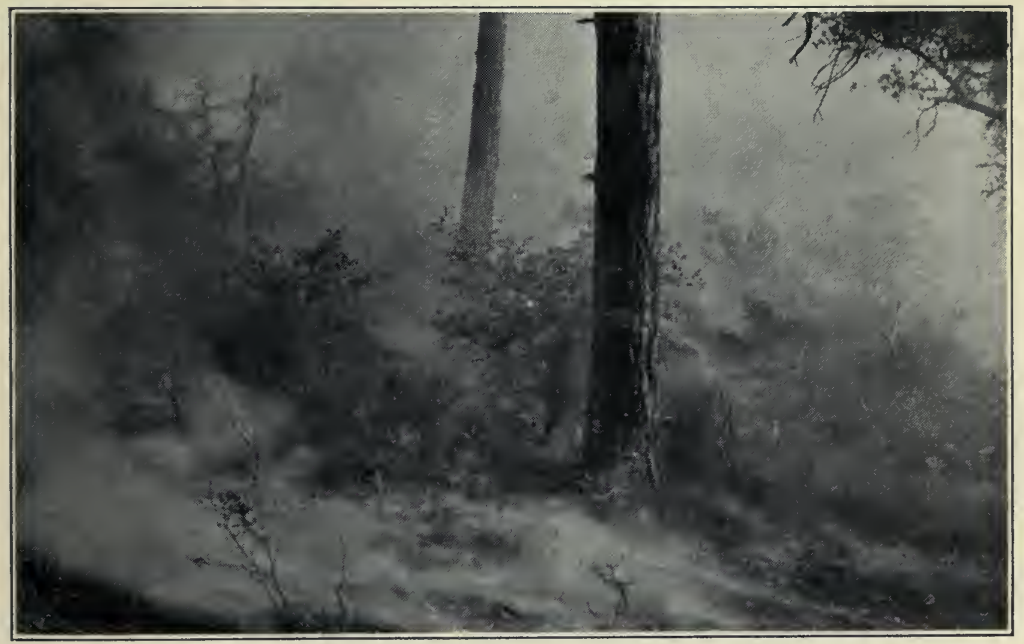

FIRE IN THE BRUSH

How the fire looked at close quarters as it worked forward to our cleared line 

sleep of every Forest Service man during the dry season.

Those of us who had never fought fire in the woods -Wallace, Wetherby, Conway and myself, were much excited. We were anxious to meet this dreaded opponent. Tales that we had heard, legends of former conflagrations, buzzed in our brains. The interest we felt in the impending struggle overcame the fear of fatigue-the natural physical aversion for the gruelling task ahead.

The older men, by contrast, were silent and serious. They knew what the call meant. They remembered similar nights of toil with shovel or rake, wet sack or pine limb flail, by back fire or cleared line, long nights passed in a death struggle with the for'sts' arch-enemy, sometimes conquering, crushing the red terror into the blackness of death, sometimes conquered, driven from the field by the fiery breath of the onrushing flames. These veterans did not lightly join issue again. Their gravity was impressive, portentous; their silent, swift preparation inspired us with the feeling that our waiting foe was worthy of our most earnest efforts, that no man might with confidence foretell the outcome of the night's work.

There was no confusion, or hesitation, once the warning came. The packers and the cook, detailed to supply water to the fighters on the line, left at once to round up the burros.

The rest of us started for the scene of action with- 
out waiting to finish supper, merely stuffing our pockets with what food came handiest. For fire brooks no delay and the same, on such occasions, may be said of Forest Supervisors.

A hike of three miles brought us to the edge of the burning area, which appeared at this time to be one hundred acres or more in extent. We saw at once that we had to deal with what is technically termed a "surface" fire,- that is, the fire fed chiefly on brush and the young growth of pine, ground cover and fallen logs, the litter covering the soil-rather than like "ground fire" actually getting a hold in the humus and smouldering beneath the surface or like a "crown fire" sweeping through the tops and branches of the larger trees.

When we arrived the fire was climbing toward the top of Hillsboro Peak driven by a mild breeze from the north. There was a fairly dense cover here which made good fuel. Also the fire was ascending and would therefore naturally travel faster than when working on a level or down hill. So the flames leapt merrily upward, sparks flew before, and it was obvious that nothing effective could be done to check their advance until the bright line of destruction reached the crest of the mountain and started down the other side.

Reid joined us as soon as we came upon the scene. He carried a long, steel shafted rake upon his shoulders. He was dripping sweat and his face and hands were blackened by smoke. 
"Glad to see you," he grinned through this grimy; mask, "she's going strong, ain't she? About all we can do now, I reckon, is get on top and cut a line. Then fight her there, just as she starts to dip down hill. There'll be a bunch out in the morning, but the real work must be done to-night. If we can hold her at the line till reinforcements come we'll win out."

So there began at once a three cornered race. With shovel and axe and rake we worked heroically to clear a fireline at the edge of the south slope of Hillsboro Peak, in accordance with Reid's directions, before the line of fire should reach the position we had chosen to fortify. And darkness, coming on apace, promised for a time to beat us both.

But we won. When the light in the western sky. faded and the jack-in-the-box stars popped out, one by one; and when finally through the gathering dusk we saw the ruddy flare of fire rise threateningly. above the line of the ridge, we were ready.

A line fifteen feet wide and four hundred yards long, cleared to the dirt, lay along the top. Behind it, resting for a brief breath-winning spell, were the fire fighters. Rakes and pine branches thickly padded with needles, shovels and wetted gunny sacks (for the first load of water had arrived) lay ready to hand. There needed nothing now to start the duel but that the crawling foe, approaching nearer moment by moment, should reach us and assault our position. It was the calm before the storm, the 
pause, impressive in its mere inaction, that serves to herald the imminent clashing of two gladiators who neither ask nor give quarter.

There were seven of us there in all: Reid, Frazer, Moak, Wallace, Wetherby, Conway and myself. This gave each of us approximately sixty yards of fire line to protect, sixty yards of rock and dirt across which no flame must win, no spark leap and live, throughout the night.

At last the moment for action arrived. Here and there tongues of fire, small wedges of burning brush, the advance guard of the main body, broke from its ragged front and sallied ahead in short, uneven rushes, as if filled with a momentary confidence, a presentiment of victory to come. But when these scouting forces struck the cleared line they halted in mid-career as a bullet stops at a wall of sand.

This was our moment. The leaping flames sank abruptly to a slow creeping line of yellow, close to the ground, and the heat, intolerable before, moderated enough to permit of our approach. We leapt forward and with swinging bough or dampened gunny sack beat out the wavering line of fire.

At first it was easy. We were keyed to effort and the burning spots along the fireline were yet few and feeble. We had frequent opportunity to catch our breath in the intervals, to rush for a moment back from the line of battle and recover from each suffocating swirl of smoke or blast of excessive heat. But these chances became fewer and farther apart. 


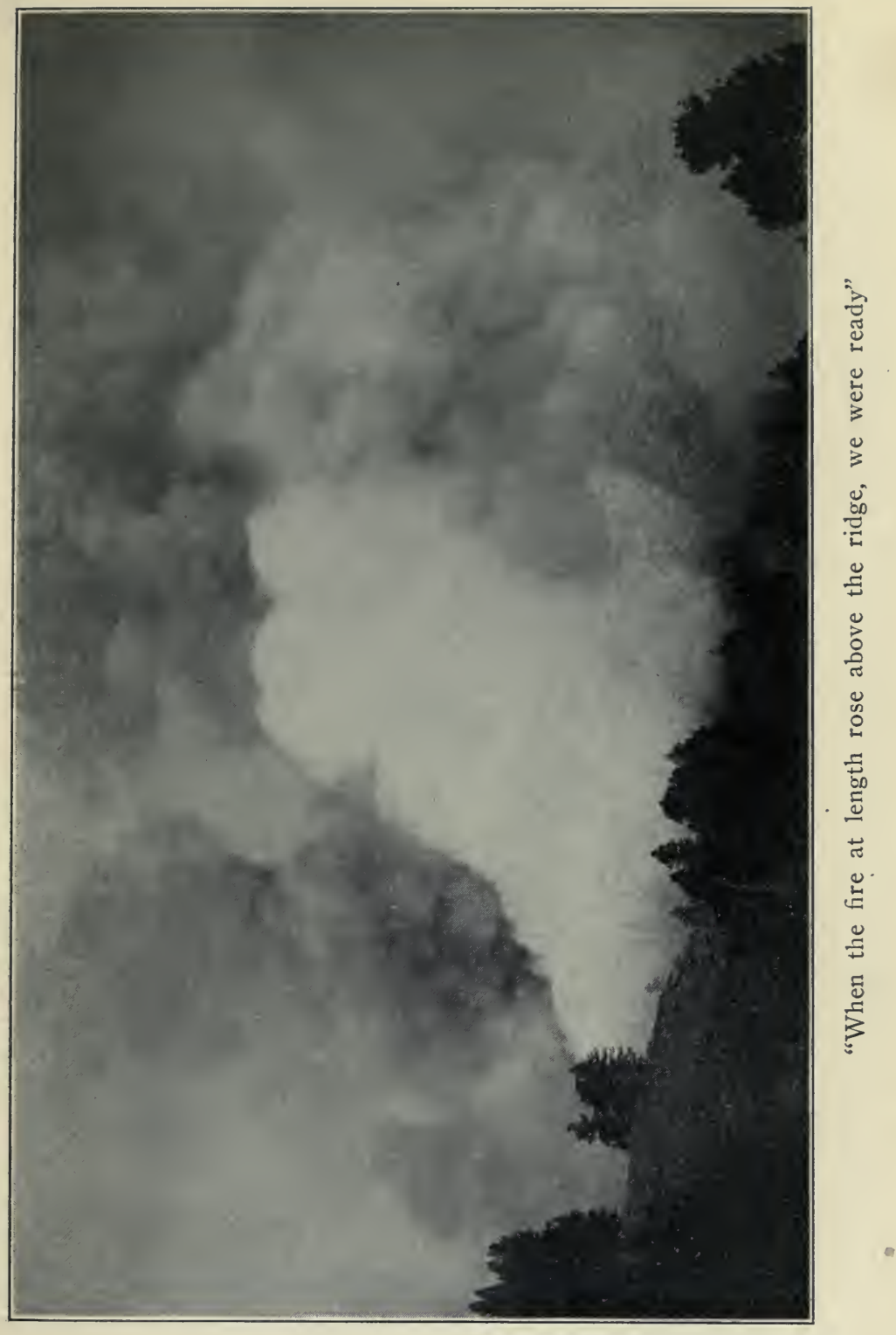



As the main fire reached us our attention was required not only at isolated spots but all along the front. More and more we found ourselves fighting a continuous line of flames, combating a hydraheaded enemy. No sooner was the fire crushed in one place than it broke out in a dozen others and we rushed off to attack them one after another.

The battle was general. Hour succeeded wearing hour. We hardly heeded the passage of time, Rushing hither and thither through the clouds of smoke, howling warnings and suggestions to one another, running to the assistance of a hard pressed comrade or calling for aid ourselves, we fought through the hours of the night, looking in the uncanny ruby glow for all the world like a crowd of imps toiling to feed the furnaces of hell.

It is hard now to remember, to pick out special scenes or incidents of that kaleidoscopic night. The picture that recollection holds fast to is blurred and smoke dimmed, just a confused, endless, ever shifting succession of bright flames springing at us out of the dark, a weary hand to hand battle with the tireless enemy, a growing fatigue that ached and throbbed like a prisoned spirit of evil and a joyful underlying consciousness, leavening and lightening all, that we were holding our own, that no hungry shred of fire had passed our defences and penetrated to the rich timbered region behind us.

We were on our feet in almost constant action till morning. Bert and the packers, between trips for 
water, offered time and again to relieve the men along the line. Horace gave out finally and took advantage of such a suggestion to swap jobs with Ewing. Some time toward midnight Moak changed places with Brown. But the rest of us, filled with the enthusiasm of the game, refused to quit.

Morning at last brought an end to the long grind. As the sun rose, bloody through the blackened air, a far off yell of encouragement came gratefully to our ears, with its cheering message of reinforcements on the way. A little later a galloping line of fire guards and cowpunchers swung up the trail and dismounted. They had ridden all night, but after a cup of hot coffee, which Bert prepared, joined energetically in the fight.

The fire did not now long resist the combined efforts of both parties. In a few hours it was surrounded and so far under control that those of us who most needed sleep could rest.

And we were ready to rest. From our sensations at this time we did not see how it was humanly possible to keep the pace we had set much longer, but instances are on record, on this same Gila National forest, of men fighting fire continuously without sleep or rest for thirty, forty-eight, and, in one instance, for sixty-three solid hours.

When it was all over we were thankful for the experience, but we desired no more. Here was the one thing we had found that was harder work, while it lasted, than reconnaissance. 


\section{CHAPTER XIV.}

\section{THE RAINY SEASON}

By June we had worked north along the west side until we reached a point level with Sawyer's Peak, where we began. This completed the horseshoe shaped southern portion of the baseline from which we had cruised the whole south end of the range. So we packed up and moved over the divide once more to jibe with our first work and work north from there along the east slope.

These runs were anything but pleasant. The east side, rougher and less heavily timbered than the western half of the Range, was for that the more difficult to cruise, and the region that we now went through seemed worse than any place we had encountered thus far. But we were becoming thoroughly hardened and accustomed to expect a pretty severe grind each day; we were getting into the swing of the work and reeling off the long, brushy runs with infinitely less effort than in the beginning.

We first tackled North Percha Creek watershed, then came a hateful little cliff bordered canyon called Cave Creek, and finally, about the middle of the month, we reached Cub Canyon. Ahead, less than 
a week's work away, was the Animas, of which we had already heard so much. We anticipated, half in relief, half in anxiety, an early encounter with this dreaded canyon and its tributaries.

But just at this time the rainy season rather unexpectedly set in. A mild drizzle began on the seventeenth of June and was followed by a steady downpour that lasted three days. We spent this time in camp, jibing the contours of adjoining runs and transferring maps and estimates from our field notebooks to permanent section plats. Then on the twenty-first Frazer decided to cross to the west side and work northward from where we had left off until the constant rain should cease.

"If we attempt the Animas now," he explained, "we'll find ourselves up against it for fair. We could never stand that and the rain at the same time."

Some of us who had never gone through a rainy season in the mountains were inclined to believe the move unnecessary, but later were prone to admit its wisdom. For besides the usual difficulties the cruiser had now the added discomfort of being wet through at least once a day.

Each morning we started out under a cloudless sky. Almost invariably, as the forenoon wore along, a storm would overtake us. It was usually heralded by a first faint mutter of thunder, just audible. A few moments later a small black cloud appeared 
above the backbone of the range and spread swiftly till it covered the whole corner of the sky. As it neared a cold wind roared dismally through the trees and a moment later rain fell in sheets, blotting out the surrounding landscape completely.

We stood meanwhile under the half shelter of a tree or rock, wet to the skin and numb with cold, and waited till the worst of the storm passed, listening to the hiss of the rain and watching the almost continuous stabs of lightning, or starting involuntarily at the jarring, crashing detonation of the following thunder.

Then, when the air cleared a trifle, we sallied forth once more and took up our run where we left off. Sometimes the rain continued; sometimes we were enveloped in chilly banks of cloud, not nearly so attractive close at hand as they appeared from a distance.

Once, on a day like this, I ran my line for a mile over a row of peaks where the cloud mists were so thick I could see not further than fifty feet in any direction. My maps, as might be surmised, were not all that could be desired.

Often, instead of passing overhead, a storm would miss us and roll by to one side or the other. At such times, particularly if we chanced to be in a place of vantage, on a pinnacle or high point, the spectacle defied description. The whole world, as we saw itmountain and valley, sky and far plain,-framed a 
gigantic conflict of elemental forces that suggested a vision of Doré's. The wonderful bigness of the sight took one's breath away.

In course of time we grew used to even these awesome scenes. All that remained from our first complex of emotion was a keen personal antipathy to cloud, rain, hail, lightning and thunder, singly and: collectively.

The most annoying feature of it all was the extreme cold that came with the storm. The rain when not frozen into hail was cold as ice and at the same time the general temperature dropped from thirty. to fifty degrees. Dressed as lightly as possible, our blood thinned by the heat and hard work, we were easily chilled. Sometimes our arms became numb to the shoulders and our feet lost all sensation. Sometimes we shivered and shook so that the contours of our maps took on that tremulous character which is used in mapwork to indicate the course of a river. But we worked ahead perforce as best we could and took our daily bath with as much philosophy as we could command.

To some of the party the lightning was a greater trial than the rain. Often during a storm the flashes came so close together that they seemed connected. Each of us at one time or another managed to get in the vicinity of a falling bolt when it struck and our nerves consequently became affected in varying degrees.

The most exciting incident of this sort occurred 
one hot night in the early part of July. We had been laboriously covering the upper Gallinas country, the Noonday Canyon watershed and the lower reaches of Shepherd Creek during the two weeks or more of the rainy weather that had passed.

It was our first camp on Shepherd Creek, and we had pitched our tents near a little side draw. Within the camp limits grew several large pines, to one of which the cook tent was lashed. Some one spoke of the danger of sleeping so close to these "lightning rods" and our conversation thereafter until bedtime consisted chiefly of reminiscences concerning lightning and its dangers.

The stars were shining when we retired. Not a cloud obscured the sky. But in the middle of the night we were brought up standing by a crash as if the heavens had fallen. The wind was howling hoarsely, the rain coming down in torrents and the lightning and thunder performing with great and insistent regularity. Through the uproar we heard, near at hand, loud yells for assistance. I peered cautiously out through the tent flap and by the rapid flashes saw a strange sight.

The tent in which Wallace and Wetherby dwelt was flapping madly in the wind, guy ropes flying and stakes pulled up. It was held only by the ridge rope, fastened to two trees, one in front and one behind. The frantic owners, scantily clad and looking like two bedraggled ghosts, jumped around the canvas in a mad effort to secure it without being 
slapped across camp by a blow from the heavy cloth.

Wetherby's was the voice we had heard. He was alternately calling for aid and anathematising the world, while Wallace, less loudly, but fully as heartily, berated his tent fellow for alleged contributory negligence.

"Doggone it!" he cried, "didn't I tell you not to fasten the ropes so tight? You might have known the tent would shrink and pull up the stakes!"

We did not hear Horace's defence. It is possible that he had none.

After an extremely strenuous ten minutes the two unfortunates succeeded in securing the tent once more. They skipped inside like rats, and had no more than crawled into their wet beds when a blinding flash and a terrific thunder clap that seemed to split the earth came simultaneously.

The air was full of flying wood and burning splinters. By the next quick flash we saw the cook tent hanging to a shattered tree. We arose at once. Bert was stunned, but unhurt-a miracle in itselfand pulling his bed into one of the other tents we left him cursing as he crawled into his wet blankets and sought our own couches.

On another occasion, a short time after this midnight alarm, a thunderstorm was indirectly responsible for about the worst scare I got during the season. I was crossing a ridge between Shepherd Creek and East Canyon when the sound of thunder first came and I made haste to descend into the can- 


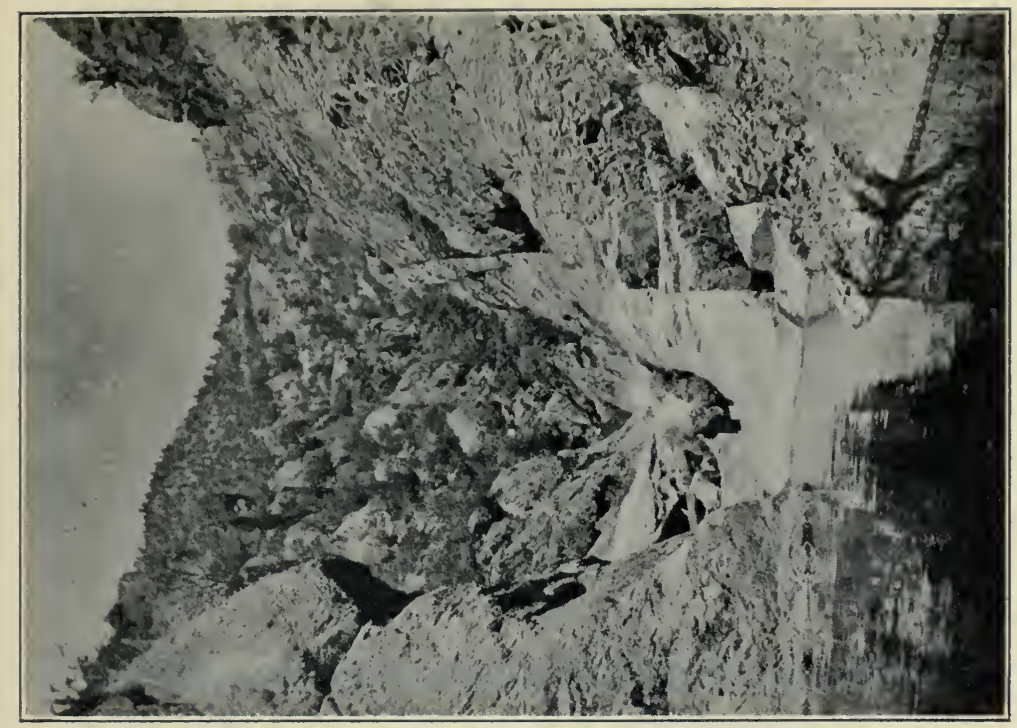

อี

2

xo

ำ

笓

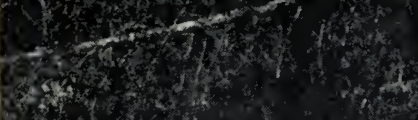

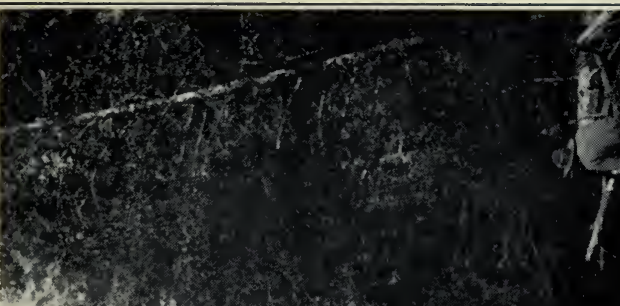

$3 x^{2}$

ting

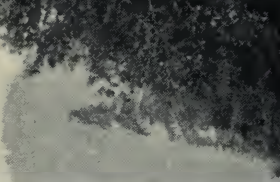

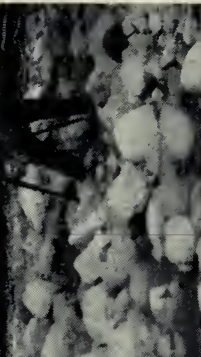

$<$

ปี 

yon, since the danger of being struck is greater on high points. Halfway down the slope I spied a pile of outcropping rocks just ahead. It looked like a good shelter, the more so as on closer inspection a cave appeared. The mouth was about three feet high and just wide enough to squeeze through. The storm was close at hand, so without more ado I dropped on hands and knees and began to crawl into the opening. Almost at once I stopped at a slight movement within, and looked up into a pair of the brightest, greenest, most fearsome eyes imaginable.

It could not have been more than ten seconds afterward before I found myself perched in a small oak, some five feet from the ground, with no recollection of how I got there. A female mountain lion, her tail waving gently to and fro, crouched close to the ground a short distance away.

I had sometimes fondly imagined a meeting of this sort, but the details in those adventures did not correspond in the slightest degree to the present circumstances. I reflected, as I drew my automatic from its holster, that facts do not invariably follow the course of mental excursions.

And at just this interesting moment I recalled with a sinking sensation that I had all but emptied my gun at a squirrel only a short time before. I was not sure whether there were any cartridges left in the magazine.

The ensuing brief pause was one of the most uncomfortable periods I have ever spent. Fortunately 
for my self-control it was but a few seconds before the lioness, who had been creeping nearer, stopped, lowered her head, and with a snarl sprang up and forward. As she rose I shoved the pistol in her face and pulled the trigger. A welcome report followed and as her body struck me and we came to the ground together I remember thinking mirthlessly:

"Well, if I missed that chance I deserve what's coming."

I arose at once, hastily, still grasping my pistol, but the lioness remained where she had fallen. My one lucky shot, entering the mouth, had blown the top of her head off. I examined the magazine of my revolver and found that it was empty. Then I began to be really frightened.

When, upon returning to camp, I related the experience to the others, Bert at once asserted that there must have been kittens in the cave I had attempted to enter.

"A lion'd never stand up to you," he said, "unlessn'n she'd got young uns. I'm goin' down tomorrow and get them."

He was as good as his word, returning next evening with two small, fluffy, tawny creatures and the skin of the old one, of little value at this time of year. The kittens were kept for a short time, but they became troublesome before long and we killed them.

As for myself, I took good care after this to keep my gun full of cartridges and an extra loaded magazine in my pocket. 


\section{CHAPTER XV}

\section{BERT SEES THINGS}

IN East Canyon we camped near Tom O'Brien's sawmill, one of the small portable outfits, with a capacity for cutting five or ten thousand feet of saw timber per day, that are to be discovered here and there in the Black Range.

The proprietor we found a genial soul whose interests seemed to centre more in the shooting and trapping of "varmints" than in the lumber industry. He showed us several good bear skins that he wanted outrageous prices for and also, which was more interesting, a tame grizzly, half grown, with which he was on alarmingly intimate terms. He boxed and wrestled with his huge pet for our benefit but warned us at the same time that he was the only person for whom these pastimes were safe. None of us tested the accuracy of the statement but it was very probably true, for whenever any one came near the boards which fenced in the bear his reception was somewhat terrifying. "Teddy" had escaped from his pen, O'Brien told us, more than once, but always turned up later after absences of varying length.

The sawmill was not an imposing affair, but we were able to study local methods and costs of logging 101 
here to advantage and as we were all pretty tired at the time Frazer decided to spend a week or ten days in the locality, going over the O'Brien timber sale area and gathering tree growth data. During this whole period the rain obligingly held off, nor did it begin again till we had moved to another camp higher in the range.

Growth study, a science in itself, we found most interesting. The work involved counting the annual rings on each tree stump left by the wood-cutters and a measurement of the stump height. From these figures, compiled for a large number of trees, the size of a tree at any given age can be determined, or conversely one can estimate how many years it would take a yellow pine or Douglas fir to attain, on the average, a specified diameter. An examination of "reproduction" was also made by which the average height of a seedling at various ages was estimated.

While stopping here we almost lost Bert, a calamity which would have changed the whole aspect of things for us for the rest of the season.

The trouble all started with O'Brien's hogs. They developed from the very start a detestable penchant for hanging around camp. And though Bert was able to keep them at bay during the day, at night they made sleep impossible with their snortings and gurglings and squealings and the loss of self-respect we felt at their propinquity.

Every evening after supper we would gather 
stones and pile them near our beds. Then just as we started to doze the first signals of the coming conflict would sound. From down the creek, from up the creek, from the slopes on either hand swarmed the vanguard of the hog battalions. Black hogs, white hogs, little and big, all sorts and conditions of hogs, swooped down in a vicious spirit of evil camaraderie upon our devoted camp.

Then the battle would join. Stones and curses rained upon the invaders. A perfect bedlam ensued, the terrified cries of the hogs mingling with the shouts and execrations of our party and the furious barking of the dogs.

For our dogs, be it said to their credit, did their part nobly. "Violet," the bull-terrier, "Nicodemus," the thoroughbred Airedale, and "Snip," the most useful of the lot, who according to Brown, his master, was of the "just dog" strain, charged the hogs time and again. Each sortie had the same result. The visitors would turn and run off as fast as they could, screaming and squealing until pursuit ceased. The dogs would then return, the fusillade of stones cease, and all would be as silent as death, for about half an hour. Then again from up the creek, from down the creek and from all round about sounded tentative, experimental grunts and gurgles and we knew that another attack was beginning to develop and end in the same manner as the firstand all the others.

This nightly combat was hard enough on all of 
us, but Bert had to spend most of the day as well fighting the intruders. He became thin and worn looking. The strain made him nervous.

Finally he lost patience. He procured a demijohn of whiskey from O'Brien and, announcing that he had "quit," started to drink it up and forget his troubles. He unquestionably succeeded in the former endeavour and probably in the latter as well, for when we came in at night he was dead to the world. We put him to bed and Brown cooked supper.

We were somewhat worried over Bert's reported declaration of desertion but Frazer did not seem agitated.

"He's just tired out," the chief said, "and felt like giving his nerves a good time. He'll be all right in the morning. Just let him alone to-night."

We were perfectly willing to accede to this request, but the stars in their courses determined events otherwise. That night there was a bright moon that lighted objects for some little distance. It brought out the forms of our enemies, the hogs, so clearly that we were able to bombard them effectively enough to keep them out of camp most of the time. In this way we managed to get considerable sleep.

We were brought out of one of the longest of our slumber spells by an unearthly scream from the cook tent.

"Take 'em away! Take 'em away for God's 


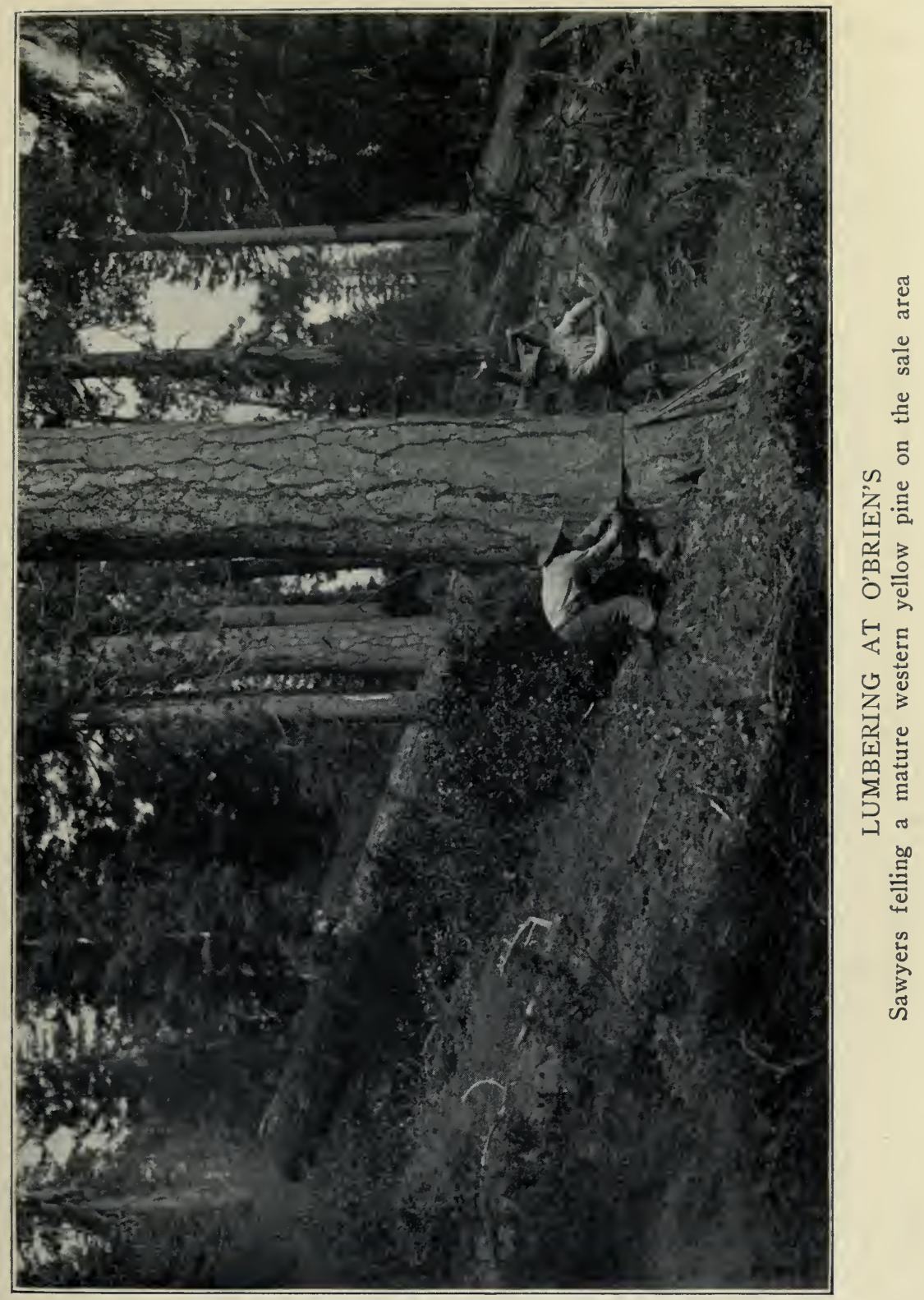



sake!" we heard, again and again, in a voice shrill with terror.

We rose at once and ran to the tent. There on his bed lay Bert, raised on one elbow, his face ghastly and his eyes distended and staring straight at a dark, ungainly shape which stood swaying upright and groping its laborious way toward his bed. In one arm it held aloft a formless figure dripping blood. By the dim uncanny light the spectacle was gruesome enough. We stood transfixed with horror as the monstrous thing advanced.

Suddenly Bert uttered a wilder shriek than all and fell over unconscious. At the same moment a ray of moonlight shining through a hole in the roof of the tent showed us O'Brien's bear, Teddy, with one of those fiendish hogs, evidently just killed, clutched firmly in his forepaws.

As Bert's yells ceased the bear promptly squatted down and began to eat the slaughtered animal. Our first terror vanished, but we still hesitated about endeavouring to influence Teddy's actions, much as we desired his absence. Nor did we wish to shoot him, since O'Brien had told us he was harmless if left alone. We were finally forced to send for his master, who tied a rope around his neck and led him home, apologising in the meantime for the trouble he had caused.

It was some time before Bert came to. He immediately swore never to touch another drop of liquor as long as he lived. Unlike most such pledges, I be- 


\section{THE LOG OF A TIMBER CRUISER}

lieve that to date this promise has been kept. He forgot all about his threat to quit and we left East Canyon and moved to lower McKnight in a few days - a great relief to all.

I have often wondered how long Bert would have stayed had we disobeyed Frazer's orders and told the cook the true story of the night's occurrences, instead of allowing him to continue in the firm belief that he had suffered from delirium tremens. 


\section{CHAPTER XVI}

\section{HORACE TAKES A STAND}

THE rain began again as soon as we reached McKnight Creek, and continued during all the time we worked that canyon.

In the very first camp we made Horace fell ill. His trouble included chills, fever, general debility and a bad cold. Brown called it "mountain fever."

The patient had been complaining for some time of various pains and aches, usually after a hearty meal, and the sympathy we might have felt for him was minimised by the fact that we were all inclined to attribute the condition from which he suffered to overeating.

None of us had delicate appetites-our work precluded that-but we were well aware that if we ate all we wanted at every meal catastrophe would follow surely. Horace alone consistently stuffed himself in spite of our warnings and the collapse of his system, we felt, was simply the inevitable result of this self indulgence.

But the sick man in turn ascribed his illness to the altitude, the water, the temperature and the work, to every imaginable reason, in fact, but the obvious one. He suffered-and incidentally inflicted suffering on every one else-for several days. Then, 
his digestive organs having rested, he began to grow better.

Frazer held a heart to heart talk with him as soon as he was convalescent.

"I think you'd better get ready to go, Wetherby," the chief told him, "as soon as you feel well enough to ride."

Horace was dumbfounded.

"W-why, what's the matter?" he stammered, scarcely able to believe his ears.

"Your work has been unsatisfactory, that's the matter," replied the chief, bluntly. "And it's because you're not only ignorant of what you're supposed to do but because you won't try to learn anything about it. You've got an idea you know it all in advance. You won't listen to men who have forgotten more about timber than you could learn in ten years. You undoubtedly know more than any of us in certain lines, but your special knowledge is of no more use in this life we're leading than Brown's talents would be if he were placed behind the steering wheel of a motor car.

"Don't think I'm trying to rub it in. I've simply made up my mind to let you go and I want you to know why. Wallace and Conway are getting sore on the deal. It's not fair to have them do part of your work as well as their own, and that's about what's been going on right along. So as soon as the packers go in to town after chuck you can go along with them." 
"My God!" cried the sick man, as he saw that Frazer was in earnest. "Don't say that! I thought I was doing all right, but I'll work harder yet. I'll do superhumanly! Just try me once more!"

Frazer did not relish the situation at all. He was used to handling men who were the reverse of difficult to discharge. More often than not they anticipated such a possibility by judicious resignation.

"I'll tell you what I'll do," he finally agreed, " I'll ask Conway and Wallace if they'll stand for another week or s.o of your work, and if they want to take a chance, all right."

Horace threatened to become effusive and Frazer hastily withdrew to consult with the others. The baseline party, after some discussion, agreed to the probationary arrangement upon one condition. Wallace stated this proposition when he said:

"I'll guarantee to keep Wetherby in good shape if he'll throw away his medicines and eat sensibly. If he won't agree to that I don't want him around at all."

"That's not a bad idea," Conway chimed in. "There's really nothing the matter with Horace but indigestion. If he's willing to diet and work, I'm willing, for my part, to stand him a while longer."

Of course Horace protested loudly when the scheme was proposed to him, but finally yielded to necessity. He cast away his pills and powders, gloomily prophesying disease and death as a result. $\mathrm{He}$ promised to restrict himself in the matter of 


\section{THE LOG OF A TIMBER CRUISER}

food. But this was not enough for Wallace, who drew up on a sheet of note paper a slender menu and presented it to Horace for the latter's guidance. Our bill of fare was scarcely confusing in its variety, so that about all Wallace did was to limit the amount of Wetherby's nourishment for each meal. Nor did he err on the side of lavishness.

Horace took the schedule and read it with care. His face lengthened perceptibly.

"Oh, gracious! A man can't live on that, Wallace," he expostulated. "I simply can't consider it, it's absurd!"'

The Forest Assistant, an equable and mild youth, if ever there was one, the last to criticise or condemn, lost patience entirely with his tent-mate.

"You make me tired, Wetherby!" he exclaimed. "We're giving you a last chance, at your own request, and at the slightest hint of discipline you act as if you were being martyred. If you don't want to follow instructions I'm through with you, that's all."

This speech from Wallace, whom Wetherby had grown to consider the one man in camp who did not misunderstand him, was a crusher. It seemed to really get to Horace, whose armour of egotism had been heretofore proof against adverse criticism. He walked slowly to his tent, silent, but with the schedule clutched dutifully in his hand.

Thereafter he followed the diet grudgingly but faithfully, and at times it was almost painful to wit- 

ness the care and anxiety with which Horace selected and slowly comsumed his allowance of food. Two spoonfuls of beans, three of rice, one potato, two slices of bread; everything was itemised and measured. And each mouthful was swallowed not lightly or absent-mindedly, as by one plethoric and careless of his abundant riches, but in the silence of a bitter concentration which grasped desperately at the transient and elusive joy. Always he left the cook tent immediately after a meal, to escape the agony of watching others eat.

This discipline, hard as it was on the patient's emotions, in a very short time worked wonders in his physical condition. During working hours the improvement was noticeable from the first.

And in the evening, instead of flinging himself down on his bed and groaning until supper time he hovered uneasily in the vicinity of the cook tent until Bert's "Take her a-w-a-a-ay!" announced that the meal was ready.

All the known circumstances of the probationary experiment were discussed freely by every one, both in and out of Wetherby's presence. It had come to be assumed among us generally that he had no pride, no sensibility. As a matter of fact Horace simply. couldn't conceive of any one making game of him or treating his pretensions as absurd. But now, under the goad of constant ridicule, it was apparent that he was beginning to take note of and resent the scarcely veiled amusement and contempt of his co- 
workers. The night he got lost and "slept out" brought matters to a head.

No one knew just how he came to be separated from Wallace and Conway that evening. As it was no new thing for him to drop behind and catch up with them later they thought nothing of his absence until some time after reaching camp, when Horace still failed to put in an appearance.

It was scarcely probable that he was hurt, we thought, as the route of the baseline had not been particularly rough. But a night in the woods without a bed is no joke, at the best, and we were inclined to feel for Horace as we slipped into our warm blankets, a little later, with a sympathetic shiver.

A storm came up during the night and our uneasiness increased. With all our guying and criticism of the missing man, no one now really disliked him to any great extent, or wished him any injury. We thought of him rather as a helpless eccentric than as a capable irritant.

Next day Frazer met the general mood when he said:

"I'm a little worried about Wetherby, fellows! Let's knock off work this morning and look for him."

But we were spared the necessity. Shortly after breakfast the "lost goat," as Conway rather unkindly called him, returned to camp, a most woebegone spectacle. His wet and wrinkled clothes, 
bleached skin and hollow eyes gave him the appearance of a shipwrecked tramp.

He looked at us anxiously, apparently nerving himself for a siege of jollying.

But in this, I'm glad to say, he was disappointed. No one spoke or smiled till Frazer said cheerfully:

"Well, Horace, how'd you make it? We were just going out to look for you."

"I've had a dreadful experience," replied the wanderer, huskily, "I forgot to take any matches with me and it was frightfully cold. I'll drink a cup of coffee and change my clothes and get ready to go out if the fellows will wait for me."

He walked heavily to his tent, leaving us with open mouths and groping minds. The thought of Horace actually proposing to work when he was not expected to, dazed us.

"Holy Mackinaw Moses," cried Bert finally, "no matches! An' he slep' out in that storm. It's a wonder he ain't froze stiff."

"And he expects to go out to-day," added Conway, "he must be crazy!"

"Don't worry, I'll see that he stays in camp," said Frazer as he hastened after Wetherby.

The chief divulged later what happened. To begin with, he ordered Horace to bed.

"You're in no condition to go out to-day, Wetherby," he said. "Just forget work for the time being until you've rested up a little!" 


\section{THE LOG OF A TIMBER CRUISER}

"No," insisted the axeman, "I'm going out with the others. I know you've all got me sized up for a joke, and I'm sick and tired of it! Not that you haven't had reason for thinking as you do. I see that now: I didn't start right. Things have always come pretty easy for me. My father made his own way, and in consequence I've always had everything I needed handed to me. I've never been up against the real thing. I've never had a chance to get on to myself. I've never known what the necessity for real, hard work was. In all my camping trips before, I've had men with me to do the actual labour. They kidded me along, I guess, because Ior my father, rather-was paying for it; and all the time I thought I was getting experience and becoming a woodsman, when I hadn't even begun to learn.

"I've made a fool of myself on this trip, I suppose. It's taken me a good while to get on to it, but I can see now how you fellows look at it. You think I'm no earthly good! But I'm no quitter," he finished, half crying with angry resolution, "and before the season's over I'm going to prove it!"

"That's the talk, Horace, old top, fly to it!" cried Frazer with enthusiasm. "If you keep that spirit you'll find everybody trying to help you, instead of joshing you all the time."

"And I thought he was yellow clean through," said Frazer, in relating the incident. "But I believe he's really in earnest! If he shows any signs 
of making good in his resolve you fellows cut out the slapstick stuff and give him a chance!"

So Horace worked that day. And from then on we noticed a growing change in his conduct and demeanour. He became another person altogether. And though improvement in actual accomplishment was slow, the new attitude-the apparent recognition of his shortcomings and his evident determination to overcome them-won a measure of respect from us all. 


\section{CHAPTER XVII}

\section{THE ANIMAS}

THE rainy season proper stopped on August 10, as abruptly as it had begun. Thereafter, we had an occasional storm, it is true, but the monotonous certainty of rain each day was gone.

We had just about completed our work on McKnight and were camped at the time near the head of that canyon, but still on the west side of the range. Just over the divide to the eastward stretched the Animas watershed. We had hesitated to cross while the rain lasted, but there was no reason now for delay in attacking that country, so preparations for the move were at once made.

I for one was glad of it. We had heard of the Animas country so often and with such a wealth of alarming detail, had discussed its possibilities so frequently, and were, in short, so obsessed with a nervous dread of this bugaboo that the suspense was becoming wearing.

We moved on Monday after a Sunday of rest. The atmosphere in camp that morning was similar, I imagine, to the tension of a squad going into battle. The smallest details of the day are printed ineffaceably upon my memory. 
I was awakened, I recall, by the sound of an axe. Peeping out from under the tarp, through the grey pall of dawn, I saw Bert vigorously splitting wood for the fire, which twinkled and smoked as if just kindled. It was a sight to make one shiver pleasantly and crawl deeper into the blankets. I lay still for a while, enjoying to the full the languorous mood: that comes over one at such times.

But something was wrong. I became for some reason uncomfortable. A shadow in the background of my thoughts took shape and form. The Animas! There came that sinking at the pit of the stomach that one feels before a race, a football game, or a fight.

$$
\text { "Ye-ah-ah!" }
$$

Bert's "get up" scream cut the silence like a siren. No time now for nervous imaginations or forebodings! Breakfast was on the way.

Answering screeches lusty, feeble, sleepy, hoarse, or muffled, came from the tents around. One by one emerged half clad, tousled, yawning forms, making single-mindedly for the wash basins by the creek.

It was growing lighter now. We could see the sun on the high peaks, though the canyons were still in shade. The cook fire leapt and blazed. We stood in a half circle about it, soaking up the grateful warmth.

Suddenly Bert's voice shrilled once more:

"Breffo! Take her aw-a-ay!"

The summons called us to a steaming meal of 


\section{THE LOG OF A TIMBER CRUISER}

bacon, beans, potatoes, coffee, hot biscuits and "lick." Our spirits, under this stimulus, rose rapidly to normal. Afterward everybody helped pack, and we were under way by nine o'clock.

It was nearly a mile from camp to the main divide, a gradual slope ending in an abrupt ascent by: a zigzag trail. The nervy little burros, urged on by. the yells of the entire outfit, made the climb cleverly.

The saddle crossed was narrow and steep. As we neared the top we saw the burros ahead worm slowly upward, stand out for an instant one by one against the skyline, then quickly disappear. And one by one the rest of us, following in single file, reached the summit and stopped.

I shall never forget that first sight of the Animas! We were on a bare and rocky ridge. No timber grew near to impede the vision. For weeks we had been picturing to ourselves this scene, but now, as we looked down over the maze of pinnacles, bluffs, rim-rock and boxes, the welter of formidable ridges and sharply cut canyons, we knew that nothing of our imagining approached this terrific fact in point of wildness or magnificence.

The whole great watershed lay open to our eyes. Timber grew thick and tall in the canyons, more sparsely on the ridges, but the entire rocky skeleton beneath was plainly visible in outline. We saw as on a map the network of waterways-veins of the drainage system-that carried the mountain rainfall and snowfall to the far plains of the Rio Grande. 


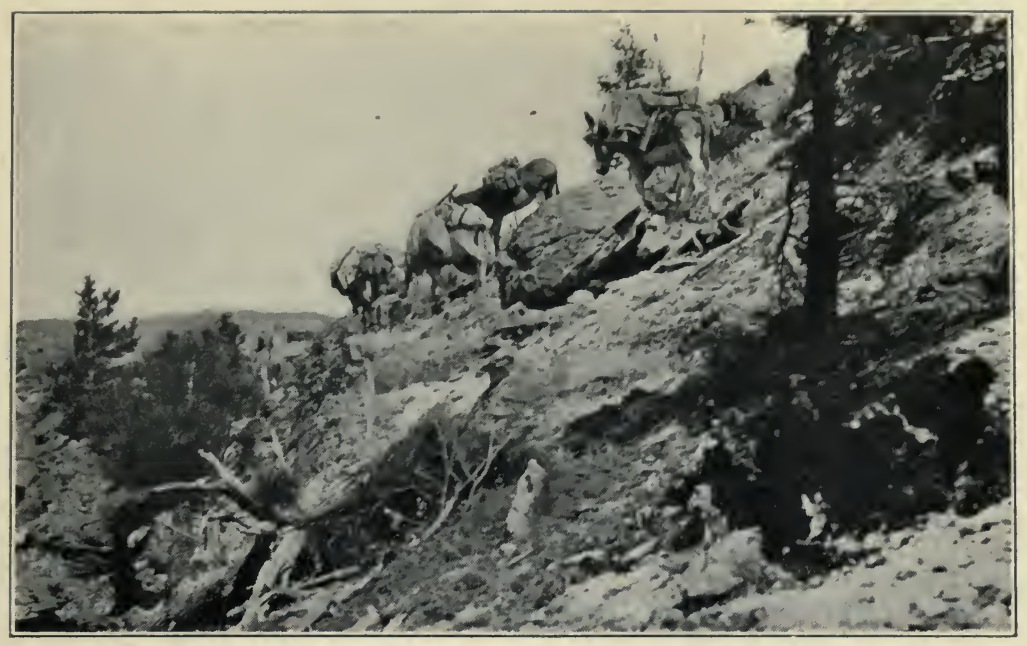

OVER THE McKNIGHT-ANIMAS DIVIDE

The burros stood out for a moment against the sky line and one by one disappeared

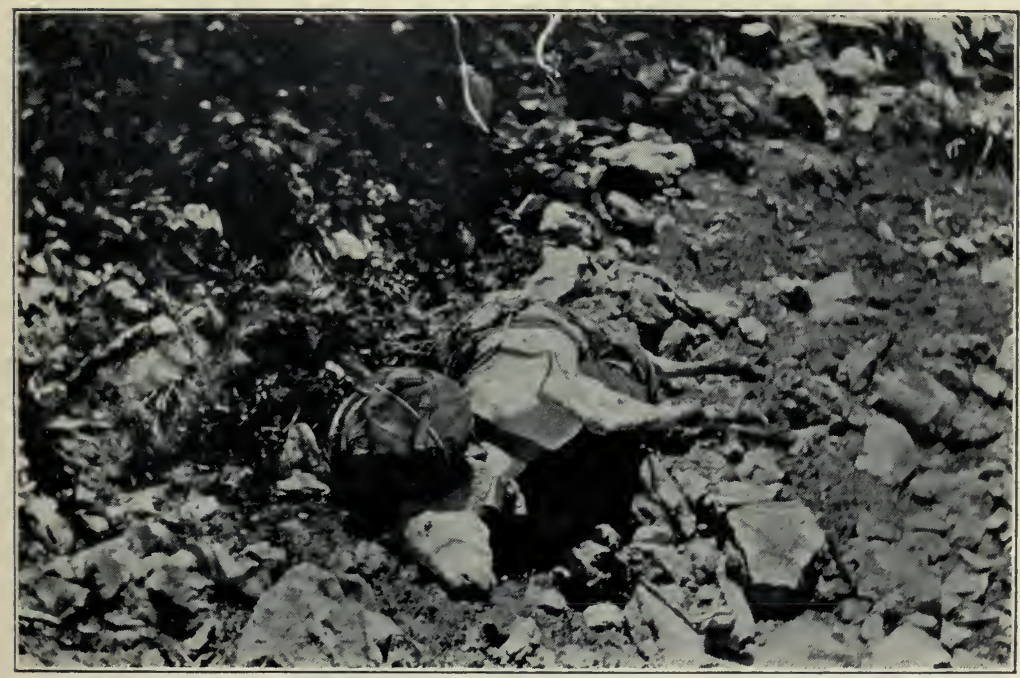

WHITEY IN DEEP TROUBLE

After a roll down the mountain with a sheer drop of thirty feet at the end 

For miles on either side, north and south, ridge upon rolling ridge shot out from the main range, constantly decreasing in height as they extended eastward. Between them were the canyons, which, beginning at the top in shallow draws, steep and boulder strewn, etched in by the overflow of snow and rain, merged ere long to make larger creeks. These in turn, further down, came together in ragged, rocky boxes, where sheer cliffs rose dizzily, and flowing on through canyons ever wider and deeper, formed the main rivers, for each of which its respective watershed was named.

The Animas proper was the chief of these final streams. The river bed itself was not visible from where we stood, but we could see the high walls of the canyon through which the stream flowed, and beyond the first confusion of mountains where the smaller tributaries came together, the two timbercovered ridges that outlined its course. Growing gradually lower and lower, these ridges flattened at length into open grassland, where the canyon seemed a mere dark gash in the soft green of the mesa.

For many minutes we stood silent, rapt in the grandeur of the scene. No wonder the Spaniards picturesquely called the place Las Animas-the Canyon of the Spirits. Its weird majesty seemed to fit the name; it looked a true abode for wandering souls or for disembodied beings.

Bert's matter of fact utterance at last broke the spell. 
"Holy Mackinaw Moses," he ejaculated, in a tone of vast respect, "they's all the original fiftyseven varieties of country there, ain't they?"

"It shore looks like a piece of God's carelessness!' assented Bob Moak. No one could add to that comment.

Our intention was to camp on the main stream, some four miles from the top. There was but one trail down, and that none of the best. It had an alarming habit of vanishing at every particularly awkward place, as if its former users had been possessed of wings wherewith to fly over the more diffcult stretches. At times we encountered obstacles that taxed even the ability of men on foot to surmount, but the packers by marvels of ingenuity and resource somehow got the burros through. About noon we found ourselves on the last ridge before the final drop to the bottom. This ridge separated the two main forks of the Animas. Where they came together it ended in a high, narrow, precipitous point, and here again the trail stopped abruptly. The descent seemed impossible but we had to get down somehow or go back to where we had started. So the packers, reconnoitring the edges, chose what seemed the least of many evils and drove the burros over.

Then our troubles began. The shrewd pack animals at once adopted a zigzag course of descent but even then, so steep was the slope, they could scarcely keep their feet. Luckily the surface rock was cov- 
ered with a fairly deep humus which afforded a foothold. This was all, I verily believe, which kept the entire outfit from immediately sliding pell-mell down five hundred feet of mountain side to the bottom.

As it was we were not without excitement of a sort. Old Red started things going. She carried the "office boxes," large wooden kyacks containing instruments, maps, drawing materials, and similar paraphernalia. They were bulky and clumsy enough on a level. And now Red had not taken ten tentative, mincing, downward steps before one of the ill-fated affairs caught against the side of the hill and threw the burro off her balance. Over she went, sideways, and began to roll.

"Good-bye Red, good-bye boxes!" sang out Frazer, dolefully. It seemed as if they were doomed. But as luck would have it, the falling animal, before she had gathered any great momentum, collided with a small tree, stopped abruptly in her spectacular flight, regained her feet and scrambled up again to where the others were. Nor did she again allow her protruding pack to interfere with an orderly, if slow, descent.

Methusalum was the next victim of the force of gravity. About half way down her breeching strap broke and the pack slipped over her head. She backed out of the harness with a skilful wriggle and standing unemotionally by watched the escaped burden go crashing down the hill. 
Later, as we neared the bottom and were beginning to breathe more freely, Whitey, who carried the dufflebags belonging to Conway and myself, slipped and went down hill end over end for a distance of some sixty yards, bringing up with a sheer drop of at least thirty feet. He landed on his back with a tremendous thump, the pack between himself and the creek bed, and lay there wedged between two rocks, waving his feet in the air and unable to turn over until we arrived at the bottom.

"There goes our 'snake bite cure," " groaned Conway, as we witnessed Whitey's catastrophe. For each of us kept a flask in his bag against emergencies and it certainly seemed as if nothing breakable could have withstood the disintegrating force of that whirlwind descent. Strange to say, however, everything was found in good shape, including the whiskey and Whitey himself, who trotted off when released with no apparent injuries.

This ended our chapter of accidents and the worst leg of the move. The rest was comparatively easy. The canyon soon widened and we struck a very fair trail that led us about five o'clock to a first rate camping ground. 


\section{CHAPTER XVIII}

\section{WORKING THE ANIMAS}

All of us except the baseline crew, Wallace, Conway and Wetherby, stayed in camp a few days on map work, while the baseline was brought over the top from McKnight Canyon and extended down the canyon of the Animas to where we lay.

Our few days' respite from physical effort was welcome. It gave us, in addition to the rest, an opportunity to examine our surroundings at leisure and to become accustomed to the sight of the awesome environment in which we found ourselves"growing a-climb-ated," Conway called it, with a tragic effort at punning.

We had time for exploring and sight seeing in addition. For the country of the Animas was rich in localities connected by tradition with stirring events of Indian and outlaw fighting. We visited among other places "Vic's Park," a pleasant, open glade on the very top of a high mountain. Here, in frontier days, the famous Apache war chief Victorio was followed, it is said, by a regiment of U.S. regulars, whom he ambushed and practically annihilated.

One of the few survivors was a negro horse wran- 


\section{THE LOG OF A TIMBER CRUISER}

gler. The story goes that this man afterward told a wonderful tale of how, while hunting horses on the morning of the massacre, he ran across a marvellously rich mass of gold bearing "float rock." $\mathrm{He}$ exhibited a piece of this as evidence of the truth of his story and announced an intention of returning before long to find the main vein. But he disappeared shortly after without leaving any more information than that.

This is the local legend, and many have been the hopeful prospectors to toil away an arduous season in fruitless search for the fabulously rich "nigger diggins," as they were called. We contributed our mite of labour to this myth, but found no gold. Brown, however, did discover in Vic's Park an old nearly decomposed army pack saddle, and nearby the bones of the animal which had, we supposed, carried it.

The park was also an excellent lookout point. The surrounding country could be seen in all its wild magnificence. And, as we gazed, something of its wildness seemed to disappear. The grandeur, the compelling solemnity of its spacious outlines, entered our souls. There was a strangely familiar effect apparent in the shapes of the vast, eroded rocks, in the slender pinnacles, the pillar like cliff formation, the whole grave spirit of the place. Frazer of all of us first hit it when he called the conception of the canyon "Gothic." That was it, indubitably. We were amid a multitude of temples. The true spirit 


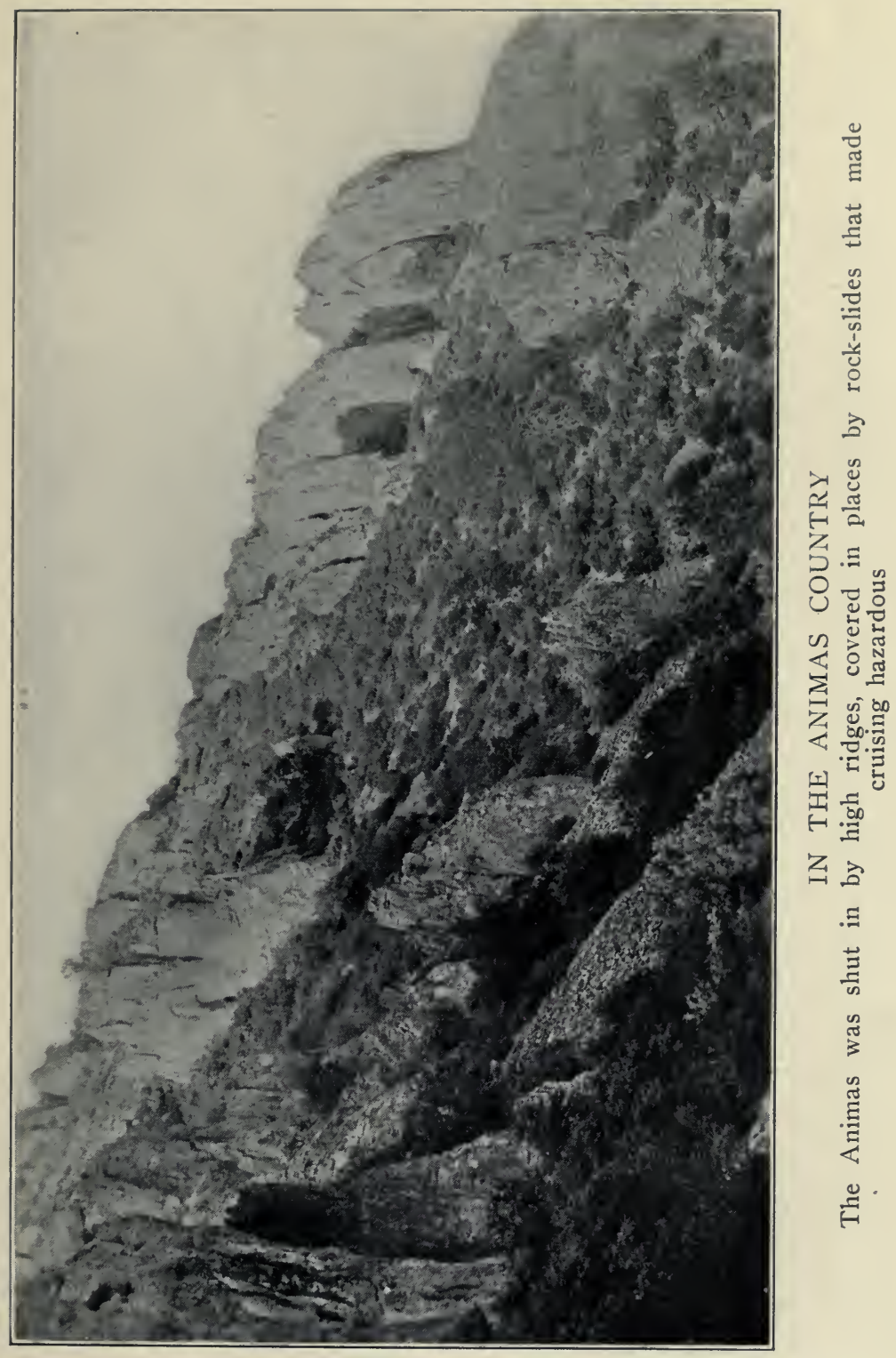



of the Gothic, apparent everywhere, sobered us like the distant chords of a great organ.

One view in particular suggested, through the magic of the surroundings and the softening atmosphere, the famous cathedral of Milan. The rock walls rose mistily blue against the sky, delicate as the work of fairies. Buttresses gleamed in the sun, great arches shone as they shouldered the mass of intricate ornamentation, of pinnacles and points, that topped the whole. Then as we looked the sun hid behind a cloud, the glistening, lacelike details were blotted out in a wave of darkness and the formless face of mystery, sombrely impassive, stared us into insignificance and awe.

We were glad, strange as it may seem, when the day came for cruising. Several things accounted. for this. In the first place we had rested thoroughly and were feeling the need of hard work once more. Then, too, conditions in camp were most uncomfortable. We had descended to an altitude of less than six thousand feet and for the first time during the summer began to suffer from the heat.

All day the sun burned down wickedly. No rain came to cool the air. Even at night, which seemed strangely unjust to us, it was warm and sultry and we slept poorly.

To make matters worse all the flies and yellow jackets in the world seemed to have appointed our camp a rendezvous. Our sun baked sleeping tents looked now like hives, now like well filled fly traps. 
The cook tent was black and swarming with the little pests. They covered the food like a pall, they committed unpleasant suicide in the coffee or the soup, it was worth a sting or so to pass the sugar or jam, and eating soon became for us the most irksome task of the whole twenty-four hours.

Our nerves and our dispositions suffered from these things. We were therefore distinctly relieved when the baseline came at last into camp and work was assigned for the following day. The runs here were planned to extend north and south; up the high, steep ridges that shut in the stream and over: into the cut up, rough country beyond where mountains and rocky. spurs tossed like waves in a choppy sea.

When I reached my first station next morning and glanced upward at the prospect before me it seemed impossible that one could ever win to the top of the first ridge. There was no hope in offsetting. On either side it was surely as bad, perhaps worse. One must simply make a beginning and trust to luck.

So I started on the arduous ascent, working slowly up crevices in the bluffs, carefully crossing the broken surface of huge rock slides liable at a false move to go rumbling to the bottom bearing the unwary intruder haplessly upon the stony crest, and up steep, bare slopes so sharp that only by the timely aid of shrubs and stunted trees could one rise at all. It was hours before I even approached the top. Below, a thousand feet and more, ran the river 
I had left. Above remained some fifty feet of rimrock, almost perpendicular, but not difficult to negotiate provided one kept a cool head. Yet just here, with the long climb almost over, a thoughtless moment brought me as close, I think, to sudden death as I have ever knowingly been.

I was two-thirds up the rampart of rock, resting on a little ledge some eight inches wide and clasping with both arms a pillar of stone whose pointed top stretched two feet above my head. It seemed firm enough for my purpose, which was to pull myself up on this until I had gained a crevice, just above, that promised to make the rest easy. As a rule we always tested the stability of a support before trusting our entire weight to it, for in a great many instances the fault, a peculiarity of formation, splits a slab from the main body so that a touch or a pull will dislodge it. But this time, careless with the thought of imminent success, I quite neglected such precautionary measures.

I reached above, grasped the top of the oblong rock and with a sharp heave raised myself with my arms. As I did so the supposedly solid mass gave with my weight. For an empty moment I felt myself falling backward. There was no time to calculate. By a lucky instinct I glanced to the right, spied what seemed to be a narrow foothold a few feet away and leapt for it.

It held! And as I clung there, suspended above the abyss, $I$ heard the great block I had dislodged a 
moment before go crashing down the dizzy slope followed by continually fainter and more prolonged reverberations.

I felt my knees begin to weaken and realised, as clearly as if I were another person, that I was very much frightened. I dared not look below. Nor could I see much chance to ascend; but it was suicide to remain where I was. It seemed an agereally it couldn't have been more than a few seconds-before I moved. Every nerve was tightly strung, every faculty at highest tension, focussed with straining single mindedness upon the one desire to scale the ten or twelve feet of stone that loomed between me and safety.

I don't know yet just how I reached the top of the ledge. So intent was I upon the task that I was unconscious of anything else. Slowly from cranny to cranny, from crevice to crumbly ledge, I progressed till at length I felt the top with extended hands. One careful pull, one cautious last exertion and I fell forward with a gasp of relief and gave way to those wretched sensations that I had managed to ignore until safe.

It was a long time before I resumed my run. And it was days before I recovered from the effects of this adventure. As a matter of fact I don't believe $I$ ever did quite overcome a tendency to nervousness that often caught me later at unexpected moments. Sometimes when clambering over cliffs that earlier in the season would have been mere 
child's play I would feel that sudden faintness, that suspicion of nausea, which preceded a fit of "the trembles," and would have to stop in my tracks, a prey to the most miserable sensations, until it was over. I used to force myself to climb the same place over and over in an effort to conquer this weakness, but it was not of much use. Even to-day when I stand in a high place and look down a wave of dizziness comes over me.

The rest of my run was as hard as any I had hitherto encountered. Up and down hill all day, one ridge after another, brush, dead and down stuff, locust and manzanita. I got back to camp at seven and found that $I$ had not been alone in my discomfort. Each cruiser had tales to unfold of brush and. heat and giant hills and impossible situations finally overcome.

Yet through the chorus there was a note of cheerfulness, of buoyancy even. We had at last come to grips with the bugbear of our season's task and won the first bout. Henceforth there might be hard work in plenty, but never again would we feel fear of our enemy, that haunting, superstitious dread that the Animas had inspired. Our imaginations were on our side now! 


\section{CHAPTER XIX}

\section{RATTLERS}

THE month that followed our invasion of the Animas is one which I have been trying ever since to forget. Everything disagreeable that could be imagined seemed to occur during this period; there were no redeeming features to the experience. It was a nightmare and no mistake. To begin with, the country we covered was consistently disheartening to cruise. It was as bad, if not worse, than the sample of the first day. The east slope seemed all of a piece. Ragged, stony, cactus covered ridges, cliffs interminable, a wretched, sun-baked, desolate stretch. There was good timber in the canyons, and cordwood upon the ridges, but the chief reason why Frazer covered this township at all was to get the country mapped so that the Supervisor could use our data in the administration of that district. For the watershed is an important one and the cattle and sheep grazing privileges thereon, as well as the disposal of the timber, is handled by the Forest Service.

The heat continued and made what might otherwise have been considered merely a case of necessary extra exertion a veritable time of torment. 130 
The flies, too, and the yellow jackets, were insufferable. Altogether it was not long before we were in a condition of nervous and physical exhaustion bordering on hysteria.

We had but one idea, to finish this desolate country as soon as it was humanly possible to do so. Each morning we woke from uneasy sleep tired and" listless. Our legs seemed lead, our feet fastened to the ground. As the day wore on we felt better and in consequence almost invariably overtaxed our: strength before night so that we reached camp thoroughly fatigued, too far gone sometimes to care even for food.

We lost weight rapidly. Every face had a drawn, gaunt look, and our nerves were in shreds. Quarrels were only avoided by limiting communication to an exchange of mere necessary civilities-themselves none too civil. Night after night we dragged in, ate in sullen silence and went immediately to our tents, where we lay as quietly as might be until darkness drove the flies to their unholy rest and afforded us a chance to sleep.

Horace, which surprised us not a little, seemed to be affected by the temperature and the work least of any one. Whether this was due to his naturally splendid constitution, given a chance to assert itself by Wallace's regimen, or grew out of his recent determination to make good in his work, or whether it sprang from a fundamentally amiable disposition or was simple perversity no one could decide. The 
fact remained, however, that during this trying time Wetherby played the rôle of Little Sunshine with something approaching success, and if not invariably blessed therefor, at least did not receive more than his proportionate share of abuse and vilification.

We finished the Animas watershed in less than two weeks, then crossed the divide north and camped in the canyon of the Seco. The work here was practically a repetition of what we had just been through, with the pleasant added interest of rattlesnakes.

During the earlier part of the season we had occasionally run across a snake, but it was an event when it occurred, a matter to be recounted at night in all its details. We were thrown into mortal terror by the angry song of a diamondback. Our course through brush, over rocks, or in fact in any locality where snakes might be expected, was marked by great circumspection. And if the dry "b-r-r-r-r-" for which we momently waited did actually sound, our excitement was real and prolonged.

In the Animas, snakes were an everyday occurrence. And while at first we went in fear and trembling, later on we grew used to them-to a certain extent-and did not mind so much.

I have always thought that Bert was responsible for the greater part of our initial terror. As soon as it was evident that snakes were out he thought up a set of appropriate yarns. The first one came the evening after the discovery of a small rattler 
which Conway and I found a few feet from the door of our tent. We were retailing the incident with a sense of importance. This was Bert's opportunity:

"You want to be careful every night," he remarked casually, "to look in your bed. Them rattlers is shore tickled to git in a feller's blankets. It warms 'em up like. Of course, if you git in with 'em and rile 'em enny they might hurt ye. It's always best to look."

We must have looked depressed, for Bert seemed pleased. After a moment he resumed:

"Ef you only had a horsehair rope with you all it'd be safer. Stretch one of 'em around a tent and a snake'll never cross it. I rec'lect how a partner of mine a'most got bit for not doing it once."

Of course we clamoured for the story. We had to, in self-defence.

" 'Twa'n't much," disclaimed Bert, "as it turned out. We wuz in a snake country and I'd been sleepin' with a hair rope round my bed just to be on the safe side. My pardner, fellow-by-name-of-Jenkins, laughed at it. He warn't afraid of no snakes, not him.

"Well, come a moonlight night a few evenings later, and I couldn't sleep nohow. Jest tossed one way an' another all night. Long about one or two o'clock, I reckon it was, I looked over at Jenkins, sleepin' peaceful like. Thar in the moonlight, right at the head of his bed, I see something bright ashinin' an' glistenin'. 
"I couldn't for the life of me make out what it was, so I raised up on one elbow and as I did I see a shinin' head rise up, too, right by Jenkins' face.

"Lordy, it give me a start. 'Twas a rattler shore enough, an' a plumb wicked lookin' varmint, big around as my wrist. 'Twas quiled up for warmth, cuddled on the edge of a blanket, snug's you please.

"When the snake seen me move it must have got scairt, for it started glidin' off silent and smooth. An' I'm blessed if twan't crawlin' away from me right across Jenkins' face.

"He hadn't moved yet, but all of a sudden he give a little start, just the littlest kind of shiver, an' then lay still again. But when I looked at him now his eyes was open, wide an' stary, and I knew he was on to what was happenin'.

" 'Lay still,' I whispered, 'don't you move!'

"I didn't never know whether he heered me or not, because at the time he didn't have much chance of showin' it ef he had an' later I forgot to ask. But he shore kep' still. Didn't even wink his eyes while that there big rattler was slippin' his six feet of scaly hide acrost his count'nance.

"It must 'a felt curyus while 'twas goin' on. 'Jenkins said afterward it sounded like a big wind blowin' mournful through the trees. But Jenkins was always a turr'ble liar, so you couldn't depend much on what he said."

Here Bert stopped as if the tale was finished. He 


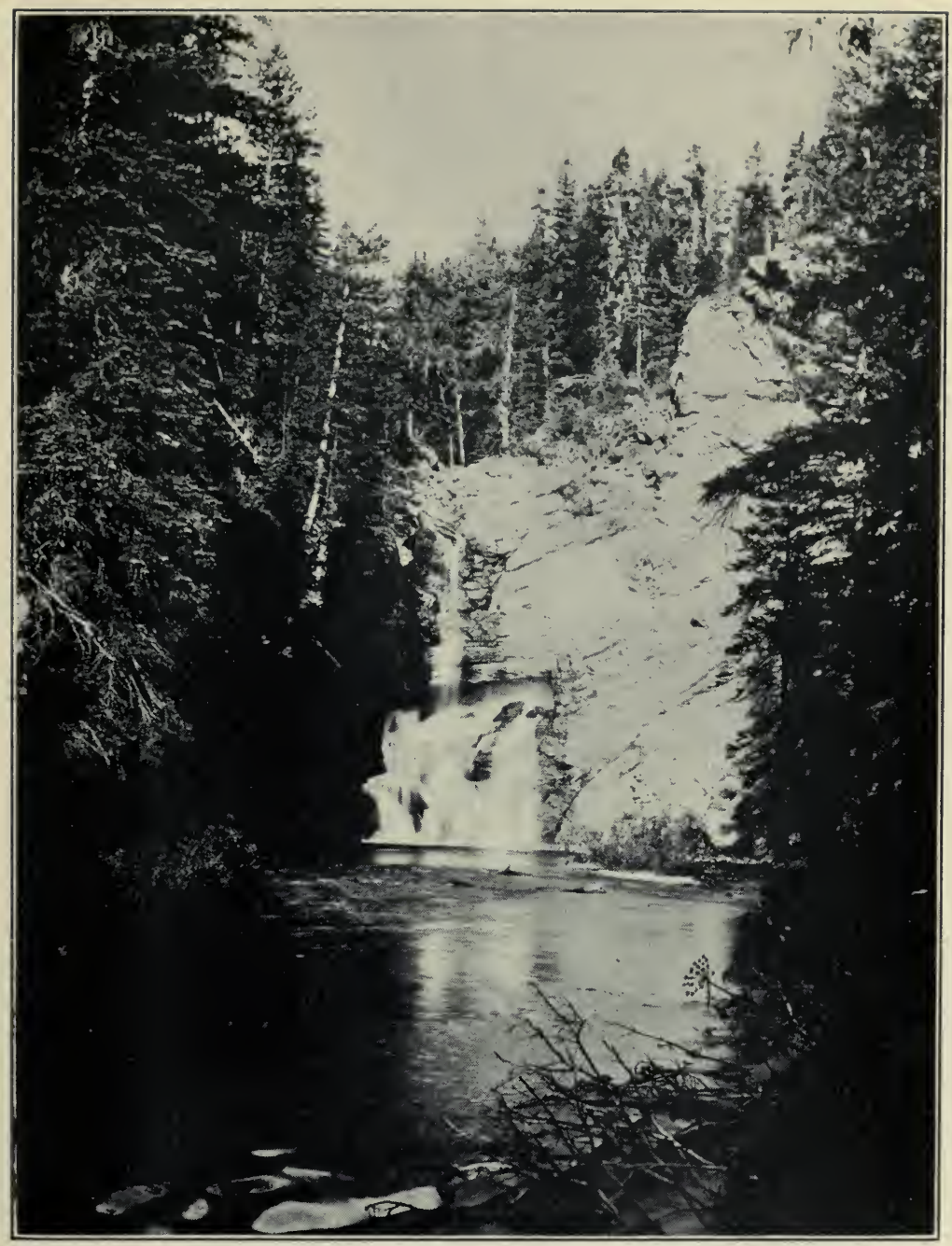

BLACK RIVER 

smoked reflectively at the fire. After a decent interval had elapsed some one asked:

"What happened then?"

Bert looked his reproach at the questioner.

"What happened then? Why nothin'. Of course, as soon as the snake got a little bit away we up an' kilt him. What I wuz tryin' to tell you was about that there horse hair rope. Y' ought-a always carry one with you."

None of us had a horse hair rope, nor did we know how such an article could be secured. But for some nights we took good care, when no one else was looking, to examine our beds for possible intruders. After a little time our first nervousness wore off. We became largely indifferent to rattlers as soon as we realised that they were more afraid of us than we were of them. The experience of running upon them became commonplace and not worthy of remark unless, indeed, the circumstances held a special thrill, as once when Frazer, climbing a cliff, poked his head above a flat rock and looked into the cold eyes of a giant rattler a foot from his face, or when Bob Moak was struck twice on the boot by a snake on which he had inadvertently trodden.

It was August, the time that skins were shed, and the half-blind reptiles struck more quickly and with less provocation than at any other time of year; but even so the danger of being wounded was negligible unless one actually stepped on a snake or 


\section{THE LOG OF A TIMBER CRUISER}

came upon one unawares, before an effective warning could be sounded.

As an antidote in case of accident we carried a small vial of potassium permanganate in each compass case, so that we felt doubly safe. Indeed, our carelessness toward the last brought us into many a dangerous situation when only a quick, instinctive backward leap, a duck of the head, or an abrupt halt saved us from playing the part of pincushion to the fangs of a waiting enemy. 


\section{CHAPTER XX \\ ON TOP AGAIN}

From the Seco we moved north to Palomas Creek, where we made three camps.

We were nearing the end now of our east work and our efforts to make the best speed possible were increased, if that could be, by the discovery that the supply of chuck on hand was nearly exhausted. It was a week's trip with the burros to Kingston, and as we moved every few days the pack outfit could not be spared long enough to bring out supplies. Unless, indeed, we halted where we were and mapped in camp till the burros could make the journey. But we had had one experience of this sort in the Animas, and one was enough. We voted to keep on till we could make camp on top, a few thousand feet higher, and do our waiting there.

In the meantime our slender stores dwindled and day by day we came to the end of one sort of food after another. Canned fruits and vegetables went first, milk and butter next, finally the last of the sugar and the jams disappeared. We were particularly sorry to see the latter go, as all through the season we had felt a consistent craving for the energy producing sweets and we could find nothing 
now that would make even a fair substitute. At noon we suffered most. We were accustomed to take with us only a couple of jam sandwiches, but though the amount of lunch was small, we missed it greatly, and scarcely ate the bread and bacon we tried instead.

At last we left Palomas and moved north again to Morgan Creek. This was a small stream in a narrow, rocky canyon, that drained about the roughest and wildest patch of country we had seen. But we went at it hopefully for we could see from the ridge the goal of our present ambition, the boundary line which marks the northern limit of the Gila and the beginning of the Datil National Forest.

In less than a week we were through. Tired in muscles and in nerves, weak from overwork, insufficient food and the heat, we still felt cheerful-for the east side was done. During the last few days we worked on bacon and beans, but did not much care. We had completed, we knew, a difficult task, asking no odds of circumstances, and we jubilated. feebly but wholeheartedly at its conclusion.

And when we hit the long trail to the top, when, as we ascended, the grateful coolness of the air from the heights struck our faces, when a little later we smelled again the damp, delicious odour of the firs and entered the soft twilight of the heavy forest, we breathed a huge breath of relief. The change had the refreshing quality of a bath after a wrestling bout, of rain following a long dry spell. 
Our week's holiday on top-for such it seemed though we worked steadily on our maps-did us all a world of good. We were camped on a little rise at the very summit of the range in a pretty grove of aspen. The camp spring was at the head of a tiny draw, which, growing larger and ever larger in its winding descent formed finally the Black River, one of the largest and most picturesque streams of the west side.

These surroundings, after our recent debilitating environment, seemed ideal. The days were clear and cool, the nights distinctly chilly. We needed all our blankets to keep warm, but the change had the effect of making us sleep like dead men, to awake each morning vastly refreshed and half famished.

The question of food, however, became rather serious. The packers left for supplies as soon as camp was made, but we were nearly out of chuck then and a week is a long fast when one is as hungry as we were. The situation was aggravated by the fact that the woods around us swarmed with wild turkey. Every morning we were awakened by the "ob-bullob-bullob-bulloble" which proclaimed their proximity.

One morning, as we came out of our tents, we were just in time to see Bert taking careful aim with a 22 rifle at some dark body in a fir not ten yards from the cook tent. Before he could shoot a flock of at least ten turkeys, alarmed by our movements, flew out of the tree and disappeared in the forest. 
Frazer was rather put out over the incident.

"You ought to know better than that, Bert," he exclaimed. "I simply can't stand for any killing of game out of season. I've got to fire the first man that does it, no matter who it is."

"Well, why can't them turkeys keep away an' leave me alone," grumbled Bert. "I wasn't botherin' them none when they came right up to the cook tent and started joshing me. I don't suppose if I was to meet one in th' road an' he run up an' bit me I'd have a right to defend myself."

Thereafter, though our appetites increased daily and the turkeys were as thick as ever, no one attempted to molest them.

We were helped out of our predicament by old man Reed, known as the "Hermit of Black Canyon," who brought us from his ranch, a short half mile away, a welcome supply of potatoes, string beans, cabbage and other vegetables which flourished there.

He was called a recluse, but his attitude toward us was most un-hermitlike. He came over to camp every evening, his daily offering of eatables in a gunnysack over his shoulder. We were always glad to see him and that not altogether on account of the addition to our stores his arrival meant. Each night he sat and talked with us a while before leaving and his graphic stories of early days in the hills, of Indian fighting and adventures with big game, were absorbingly entertaining. 
If the Hermit's unexpected sociability surprised us, we were totally unprepared for his appearance and demeanour. Rumour had painted him a fearsome person. His reputed exploits were many and terrible. He had come here thirty years ago, they said, broken down in health and finances, had settled on his inaccessible homestead and held it ever since despite all manner of obstacles contrived both by man and Nature, each year adding new land to that already under cultivation, cutting deeper into the surrounding forest and carving his domain inch by inch from the stubborn wilderness about him.

We thought to see a huge, half wild savage, but Reed was small, mild in appearance, easy and gentle in manner and voice. He was essentially commonplace. One could have imagined him sitting on a cracker box in some New England village grocery, discussing politics and local issues. Bert's designation of him as a "Hilltop Reuben" seemed appropriate. Yet from all accounts, others as well as his own, his had been an adventurous existence, replete with thrilling encounters and hairbreadth escapes from death.

It struck me that his life nowadays must be tame and rather lonely. But he quickly dispelled this idea.

"Lonesomeness is nothin' but a habit," he averred in answer to a suggestion along this line. "When I first came here I was too busy with the varmints and mebbe once in a while an Indian or 
so, to get very lonely. Then arter a while I found I'd forgot how to be.

"Course I like to see people once in a while, to kind of git my tongue loosed up; but when they're gone I don't never miss them none."

Despite this assurance I suspected a hidden tragedy, some old romance, beneath the Hermit's blithe exterior, to account more fully for his voluntary and continued exile here on the very top of the dark mountains.

I hinted as much later to Brown, who knew old man Reed well, but he scouted the idea.

"He jest lives up here because he likes it. $\mathrm{He}$ struck a good thing and helt onto it. They hain't nothin' else he could make such a good livin' out'n.

"That's one thing your National Forest is doin'," reflectively added the packer, who in general, more to irritate us if possible than for any other reason, affected to look with scepticism upon the value of Service work. "I gotta say you're givin' the reel settler a chance. Of course ole man Reed was here long before the Forest was a Guv'ment affair, but they's plenty more places like his homesteaded under Forest Service reg'lations, an' better than his ranch was when he come here."

"There are over two hundred areas listed now on the Gila," I put in, "as land suitable for agriculture and open to settlement under the act of June 11, 1906."

"Yes, an" they's a good many hundred more 

ready whenever people want 'em," returned Brown. "Of course they ain't no fortune in them right away, but making a livin' isn't hard here, if a man'll work, an' before long, if the Forest Service keeps timber thieves an' fakers out the way they're doing, they's goin' to be a sight of people comin' in here an' tickled to death to get one hundred and sixty acres of good land just by livin' on it an' workin' it."

This was all true but I was familiar with the facts that Brown offered. I was more interested just now in Reed and his history. I could not easily give up my romantic conception of the genial old mountaineer, despite Brown's matter of fact view of the situation.

"It may have been his drinking, after all," I murmured half to myself, for I had heard that he had formerly been given to the habit in excess. "He probably feels that this is the only safe place for him, the only way after his struggle with rum that he can avoid temptation!"

"Who, him?" burst out Brown, with a guffaw. "He gits roarin' drunk twice a month regular as clockwork. Most all his vegetable money goes for booze."

I began to fear that my attitude toward old man Reed might have to be recast and modelled on fact, after all, instead of fancy. 


\section{CHAPTER XXI}

\section{THE END OF EWING'S STORY}

So quickly did the time pass in our new camp on the mountain that it seemed but a breath before the day arrived on which we might expect the return of the pack outfit. But night came with no sign of the absent burros, and three more days passed before the jingle of bells and the faint cries of the packers announced their approach. It was late afternoon when we first saw them. The burros were creeping slowly, like a string of heavy laden ants, up the long, winding trail. Behind them came two horsemen.

Nearer and nearer they climbed. Brown's weird scream rang out from time to time. We had heard it before ever its perpetrator came in sight. But his companion did not look like Ewing. Before long we could distinguish the square, stalwart figure of Jackson, the Kingston ranger.

Speculation immediately arose as to the cause of Ewing's failure to appear. The general opinion was that he had gone on a bender.

Inquiries were made of Brown as soon, almost, as he had come within earshot. But the packer was for the time being uncommunicative. Jackson was equally dumb. 
"Wait till after supper," Brown finally said, "I'll tell you all about it then."

So we possessed our souls in patience until the burros were unpacked, the chuck piled away, and supper finished. Then, pipes lit and at ease about the fire, we clamoured for the news.

It was a delectable moment for Brown, who prepared to make the most of his opportunity. He seemed in no hurry to begin. Finally, however, he took a deep pull at his pipe, glanced sombrely about the circle and inquired:

"What-th'-hell d'you suppose Ewing's gone an' done?"

Since this was precisely what we had been trying to find out we assumed the query rhetorical and refrained from comment.

Our informant, after a pause, answered it himself. "The crazy son-of-a-gun," he said, "done kilt a feller the same night we got in town an' surrendered to th' sheriff d'reckly after. They got him in the jail at Hillsboro now!",

Here was news with a vengeance. If Brown anticipated a sensation he was not disappointed. Everybody asked questions at once. We were all tremendously excited. I asked:

"Who was the man killed? Anybody you knew?"

"Gimme a chance!" pleaded Brown, outwardly testy, in reality enjoying the situation thoroughly, "an' I'll tell you the whole story.

"You all remember the day we started? Well, it 
taken us three days to make it in to Hillsboro. No sooner we got unpacked than Ewing hikes over to the saloon like he was snakebit an' starts a-hittin' her up.

"I went along behine and taken a few drinks with him. Afterward I done what I could to git him to quit, but t'warn't no use. So I went over to the hotel an' et supper.

"When I come back they done got Ewing into a poker game. He was drinkin' right smart of whiskey, but didn't seem to be drunk noways bad. An' he was sure playin' cyards.

"They was five in th' game, Harry Mallory, th' tin-horn, Jim Riggs and Stub Whitcomb, from over to th' Bar 6 Ranch, Jasper Hudson, an' Ewing. Ewing was a-workin' 'em over proper.

"As I come in they was jest drawin' cyards for a jackpot.

"Ewing looked at his hand an' opened her for five dollars. He shoved in a stack of blue chips a cat couldn't jump over, an' jest then I seen a stranger step in kind of easy like and walk up behind Ewing's chair, lookin' at his hand over his shoulder.

"That's all he done, jest looked over his shoulder an' stepped back a little, smilin'. But he sure give me the creeps. He was jest a common cowpuncher, anybody could see that. Only his face looked plumb onhealthy, kinder white an' shiny in the lamp light. 
"At the time I didn't think much of it, though, an' I don't reckon nobody else did neither. Sweaters was thick in there an' what with the heat and th' tobakker smoke we wasn't expectin' nobody to look like no posy, as th' feller says.

"Well, Mallory come in the jackpot when Ewing opened her, and so did one of the cowpunchers. They each drawed three cyards. All on 'em holp, an' the bettin' was kind o' swif' for a minute. Then a call come an' they showed down, with Mallory an' Hudson holdin' threes an' Ewing flashin' tens full on queens.

“ 'Holy Moses!' says Mallory, ' $j$ 'ye ever see such luck!'

"' 'I allus have pretty good luck一of a sort,' says Ewing.

"I remember him sayin' that an' shufflin' th' cyards for deal, because jest then this here stranger I tells you about steps around the table, across from Ewing, an' pokes a 45 cannon in his face.

"' 'Yes,' he says, 'an' you're goin' to have some more o' that luck,' he says, 'right now! $Y$ ' been follerin' me around long enough. You're either goin' to promise me t' hotfoot it back where you belong, or I'll jest about blow the top of your head off.'

"Nobody knew what the feller was talkin' about, but he shore looked mean enough $t$ ' turn milk. He was shore pizen, that feller. 
"Ewing didn't seem much worried. He jest looked up at the feller an' smiled an' seemed real glad to see him.

"'Whenever you git good an' ready,' he said, 'shoot ahead!'

"The feller grinned, awful sour-like, an' sezzee, 'You'll mebbe want t' think o' your sins,' he says, 'fer a little. I'll count ten.'

"Ewing only laughed at th' feller. He shore had his nerve with him.

"The feller begin to count, an' then, jest as we heard 'eight' counted, Ewing looked right past him towards the door of the saloon, same as if he seen somebuddy, and he shouts out, quick and suddenlike, 'Millie!' Jest like that-'Millie!' Th' stranger give a jump an' half-turned around-an' there's where Ewing got him! Right through th' head! 'Twas the prettiest shot $y$ ' ever want $t$ ' see!

"He never looked at th' feller wonct after that. Jest called in th' sheriff an' give himself up peaceable.

"What gits me is just who the feller was an' why he tried to put Ewing out. An' what was Ewing a-hollerin' that there gal's name fer. Hit's shore funny. But nobody don't seem to know nothin' much more than what I tole you."

I had no doubt, under the circumstances, as to who the dead man was, and I wondered whether the outcome of his search had helped Ewing to find peace, or whether his ill luck still remained, whether the 
killing would prove for him a way to happiness or the road to a hopeless hell. I was answered, in part, a few weeks later, when the news of the packer's suicide reached us. He had gone out on bail, furnished by a cattleman he knew, taken a room at the hotel, locked the door, and shot himself.

The tragedy shocked us inexpressibly. We could think of nothing else for a time. Knowing more than the others of Ewing's story, I felt sick over the affair for days. Then, the first sudden horror of the shooting over, we began to consider its practical results. Ewing's place must be filled, and at once. But Jackson, as soon as the question was broached, set Frazer's mind at rest on this point.

"I 'phoned to Johns at Silver," he said, "as soon as I heard of the matter, and he told me to ride up and help you until you can get another man. There's not much doing in the district right now anyway, and Randolph at Fierro can look after things here for a while. I wouldn't be surprised if the Supervisor would let me finish out the job with your outfit. The fire season is over and he's cutting out all unnecessary men at this time anyway."

That, as it turned out, was just what occurred; Jackson remained with us until we struck for Silver City. 


\section{CHAPTER XXII}

\section{OLD MAN REED}

From our camp at the top we worked a strip of country about six miles long-north and south-by two miles wide. During these runs we covered Yellow Jacket peak, the highest point on the range, which we found to be over ten thousand feet in altitude.

While nothing like as disagreeable as the work on the east side, this was as hard cruising as we had encountered. For beside the steep, long climbs, a great part of the forest had been burned over here, and the one time timber was replaced by a thick young growth of pine and fir, mingled in most places with aspen and Mexican locust. In spots this cover, higher than a man's head, was so closely set and interwoven that it proved well nigh impenetrable. When one considers that it grew often on a slope of from sixty to eighty per cent grade, that loose boulders and malpais lay hidden in the long grass beneath the tangled thickets, and that the slippery dead and down trees were piled in spots as thickly as an abattis, some conception of the difficulty of the cruiser's task may be formed.

I remember one day when it took me three hours 150 


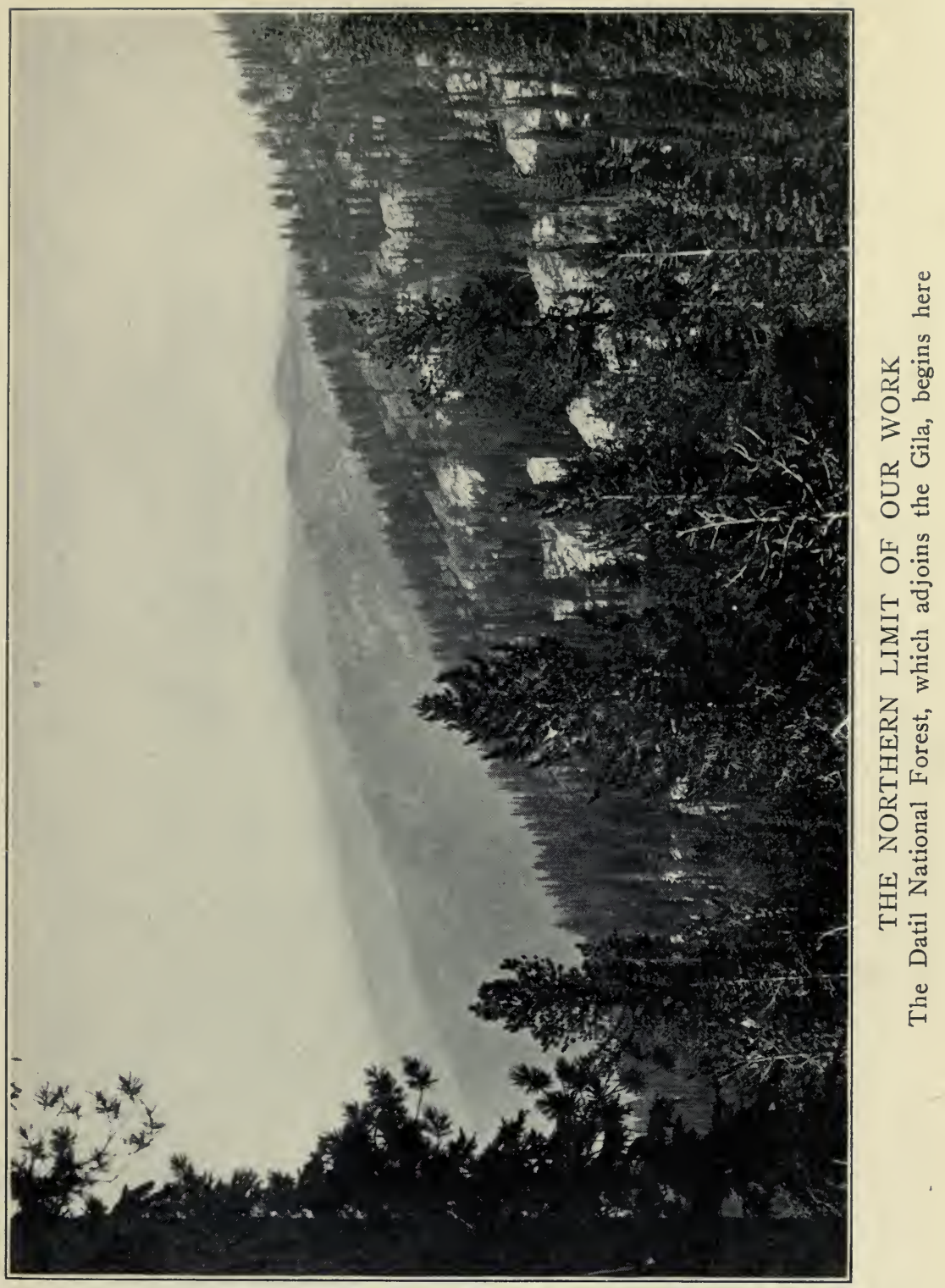



of the most strenuous sort of work to cross two forties of such stuff. And at the finish I felt as if a full day's work had been already done. One reason for this was that the footing was extremely bad and the shoes I wore were too light and thin for the job.

This question of shoes was one which bothered me all the season. The Black Range seemed to render experience in other localities regarding footwear of no value whatever. I started in on fairly heavy: shoes of the driver type, hobnailed thoroughly. A pair of nine dollar boots of this kind lasted about a month. Then a series of experiments began.

I sent to a prominent firm of sporting outfitters for the best and strongest shoe they put out. A pair cost me ten dollars. They were beautifully made and easy to the foot, while they lasted. In a week the sewing that held the counter on was cut through. In two weeks the counter itself came off. In less than a month the leather on the soles, between the nails, was eaten away as if gouged with a knife, and shortly after the nails came out and the whole shoe practically fell to pieces.

Meanwhile I had written to the makers, detailing: my experience. They replied by offering to build for me, at fourteen dollars, a pair of boots which they stated could be guaranteed for any country.

When these came (for in a fit of desperation I gave the firm carte blanche), I did not wonder at their confidence. The boots were of heaviest sole 
leather, reinforced everywhere, with counters riveted on, and with the soles thickly studded with huge Hungarian hobs. Broad steel edging nails bound the soles and heels till it seemed as if nothing could destroy them. Brown immediately christened them "the bear traps."

I was unable to give these massively made affairs a thorough test, unfortunately, for after a few days' use I decided that if I had to carry them over the hills and valleys of the Black Range during the rest of the season life would not be worth living. They weighed together, by the way, just a little over eight pounds.

Frazer, before this, had hit upon what he considered a highly satisfactory arrangement. Instead of paying a big price and getting the heaviest kind of footwear, he went to the other extreme. He purchased several pairs of light, low athletic shoes, had them solidly soled and hobnailed, and wore each pair till it showed signs of giving out, then threw them away. In this way he not only got three or four pairs of shoes for what one expensive pair cost, but possessed the advantage of carrying much less weight on his feet where every ounce counts.

The drawback to his scheme, applied personally, was that my feet were apparently not made of the same material as Frazer's. I had put on a pair of his shoes and was discovering this fact on the run I had begun to describe when the digression on shoes began. I could feel the rocks through the soles, 
sides and counters, and before long I was so lame that I could hardly walk. Though I made what speed I could it was long after supper time before I finished my day's work and started for camp.

On the way home I passed by Reed's ranch. The hermit was seated on the wooden steps of his cabin, smoking a corncob pipe. He insisted on my stopping for a "bite," and afterward we sat in his little front room-for his was a four-room edifice-and talked an hour or more away. That is to say, the old man talked and I listened. He was quite deaf, and as a rule spoke in answer to the suggestions of his own thoughts rather than to another's questions.

"I had a partner once," he announced, after a short period of rumination.

I nodded my interest in the fact.

"Ye-es," continued the old homesteader, "an' Jake was a purty good sort of feller-purty good. He was a worker, too, best I ever saw. But tetchy -awful! Nobody couldn't never pass no remarks about Jake's doin's or Jake hisself, withouten he'd up and git plumb ornery about it. Said he didn't see no call for nobody t'git curyus as to what a man was a-goin' to do or not goin' to do or why he done it, neither.

"I reck'nised Jake's failin' all right, but I was never one to humour a man over much, and Jake an' me used to have some right smart spats sometimes." The hermit smiled, gleefully reminiscent. 


\section{THE LOG OF A TIMBER CRUISER}

I could imagine some of those tedium destroying spats.

"What became of Jake?" I shouted.

"Hey! Oh, we'd been quar'lin putty reg'lar and Jake come in one night and hung up his hat on one of them nails over yonder, an' while he was washin' up for dinner I sez to him, says I, 'Jake, what ye been a doin' this arternoon?' He jest grunted an' set down to supper and never said a word endurin' th' meal.

"Afterward Jake gits up an' starts off fer th' barn plumb mad, fergittin' his hat, he's so putt out over my questionin' him thataway. 'Whar y' goin'?' I hollers after him, not thinkin' he'd answer, but he does. 'Oh I'm jist goin' t' hunt th' burros,' he says, mighty sarcastic.

"Well, sir, that was four year ago, and I hain't never laid eyes on Jake sence. An' them two burros he went $t$ ' hunt, they dis'peared 'bout th' same time."

The old man chuckled inaudibly, sucking his pipe with vast enjoyment.

Just then there sounded a rousing knock at the door. Reed stiffened, shifted in his chair, took his pipe in his left hand while his right lay negligently in the vicinity of his hip pocket, and cried out, "Come in!"

There entered at the summons a little, weazened man with bowed shoulders and a preternaturally solemn countenance, wrinkled as to forehead and 


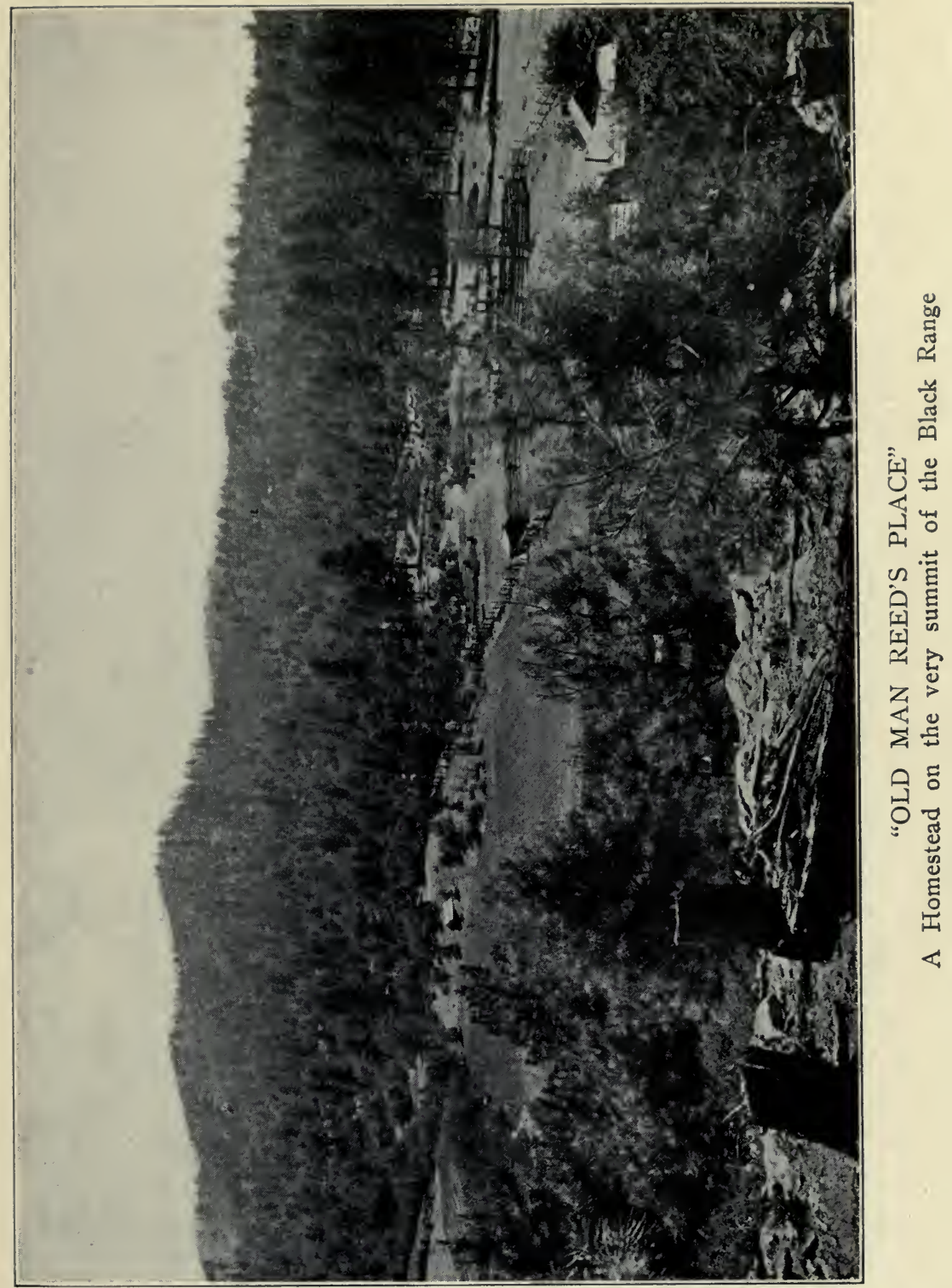



querulous in expression. He glared ferociously. at Reed, apparently more from embarrassment, however, than from ill will.

"Well, Jake," ejaculated the hermit, after a brief stare of surprise, "did ye find them burros?"

"Uh-huh!"' responded the quaint looking personage addressed. Then, as his gaze wandered to the nails along the wall, he coloured violently.

"Where 'bouts is my hat?" he complained, "seems like a fellor can't step outside but what some dum galoot has t' move his b'longings."

The hat, after a short search, was produced intact. When I left a little later the two old cronies were talking together as cosily as if they had never been separated for a moment.

I heard sometime after that another quarrel had taken place and that Jake had left once more. This might have occasioned a sad condition of affairs at Reed's ranch which we observed when next we saw the hermit and which will be described in due course. 


\section{CHAPTER XXIII}

\section{HORACE "COMES BACK"}

WHILE camped on top we spent a few days taking sample acres. The stand of timber, a composite type of pine, spruce and Douglas fir, with fir dominant, was so different from that on the sparsely cowered eastern slopes that a complete readjustment of our standards for estimating was necessary to meet the new conditions. For whereas the yellow pine that we had cruised through from the Animas to Morgan Creek did not run to over eighty or ninety thousand feet, board measure, in an average forty acres, our sample plots indicated that the stand on top for all species would probably scale from eight to twelve thousand feet an acre-three to five hundred thousand feet to the forty.

We found, later, that this computation was not far off. In some spots we struck such an estimate would have been short of the actual timber standing. A number of forties cruised carried all of four hundred thousand feet of pine and fir, while for the Black Canyon watershed alone we set our final estimate at approximately ninety million feet of standing timber.

It was necessary also at this time for the baseline 
to be carried forward along the main ridge to the Datil and then south down Diamond Creek as far as our next camp. For there now remained of the formidable forest we had attacked in May only a block of country to the west, stretching from the Datil on the north to McKnight Creek on the south. And we planned to work this territory, so far as possible, from the canyons where the baseline was to run. Our camps would be along the streams, which flowed in a generally westerly direction and which cut the timbered area for the most part into easily accessible strips and wedges. Diamond Creek was the northernmost of these main watercourses and a first camp site was chosen near the trap corral of the Diamond Bar outfit, some four miles from the canyon head.

The journey of the baseline to this point was made memorable by an exploit of Wetherby's which boosted that young man's popularity higher than it had ever before been registered by the thermometer of camp sentiment.

The crew was running the line down a narrow ravine that breaks west from the main range a little this side of the forest boundary. It was late afternoon, nearly time to knock off work. Conway walked fifty yards or more in advance of the others. Wetherby, at the moment, was helping Wallace with the plane table.

At a sudden unusual sound in the brush to the left, Wallace turned aside to investigate. The next 


\section{THE LOG OF A TIMBER CRUISER}

instant he came back at full speed, eyes popping and legs working wildly. Ten yards behind him, snarling and fighting the brush, lumbered a full grown cinnamon bear. He was in a towering rage, caused very evidently by a steel trap and eight feet of heavy chain broken from its fastening that trailed from his prisoned hind foot. Had it not been for this drag he would doubtless have caught Wallace before the Forest Assistant had gone twenty feet. For an angry bear, despite his awkward looking mode of locomotion, can make astonishing speed through the woods. As it was Wallace was able to reach an oak tree and shinny up the trunk, which was only about seven inches in diameter, before his pursuer reached the bottom.

I suppose the theory was that no bear would climb so small a tree-or perhaps the frightened youth merely made instinctively for the nearest temporary. refuge. However that be the beast hesitated not at all but began to ascend the trunk as swiftly as his clanking, unwieldy burden would permit. He made hard work of it. His roars of rage proclaimed the pain he must have felt as the ruthless steel claws of the trap in which he had been caught pulled and twisted at his torn flesh. But he worked gradually though slowly upward. He would, without doubt, have succeeded in reaching his quarry had not a timely interruption occurred.

When Horace first saw Wallace with the bear in 

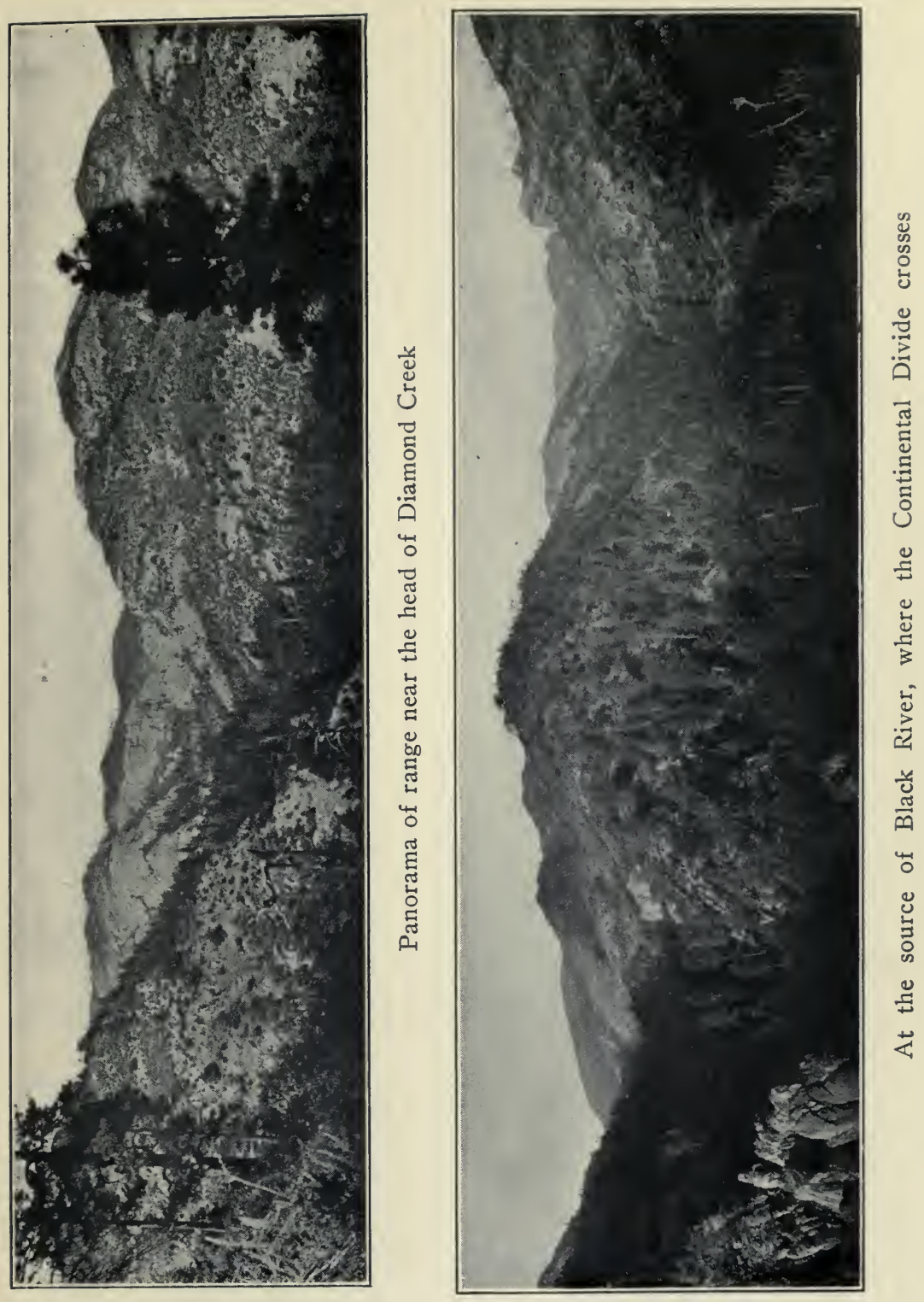

his wake emerging at high speed from the brush, he at once followed a natural and compelling impulse to climb a tree, from which position of vantage he watched the subsequent proceedings. Conway, hearing the commotion, but too far away to discern its cause, ran back toward the others. He was halted as he neared by a warning cry from Wetherby, then he too sought a convenient oak.

This was the situation as the infuriated bear began to climb the tree after Wallace, who carried no weapons, and was therefore compelled to rely upon his agility alone for safety. As soon as he saw that the bear intended to follow him he moved as far out on a limb as he could, hoping that at the worst the animal, if it persisted in its attempt to reach him, would precipitate both to the ground and give him a possible chance to escape.

The three men, each in his individual tree, watched the bear's progress intently in a state of high suspense. As it became increasingly evident that the beast would succeed in reaching him, Wallace cried out involuntarily.

Wetherby immediately began to descend from the limb on which he sat, calling out at the same time to his beleaguered chief :

"Sit tight, Wally! I'll be over in a minute!"

"What 're you trying to do, Wetherby?" cried Conway, as he realised the other's purpose. "Don't be a fool!" 
Horace did not even answer. The only one of the trio to carry a revolver, he was bent on making his much-maligned Colt justify its existence.

But to go gunning for an angry bear not ten feet off the ground with a 38-calibre pistol is distinctly a risky business. Wallace as well as Conway endeavoured to turn Horace from the attempt.

"Go on back, Wetherby," yelled his superior, as the axeman approached. "Shoot him from the tree. He'll get you sure now, if you wound him!"

"I haven't enough cartridges to waste any," was all Horace vouchsafed as he stepped directly under the tree and took careful aim at the beast above.

A shot sounded and the bear's head snapped to one side as if struck sharply with a club, his great muscles relaxed and he slid scramblingly down, in the descent his heavy claws ripping long, deep grooves in the bark of the tree.

Horace circled about, excited but alert, waiting to put five more soft-nosed bullets if necessary in the carcass of the wounded animal. A moment's inspection showed that they were not needed. The first ball, entering behind the ear, had penetrated the thin coating of muscle there, cracked through the skull, and pierced the brain. It was a perfect shot.

"I didn't know you had it in you, Horace," grinned Conway, as he slapped the delighted marksman on the back. And Wallace, with a silence more 
eloquent than a torrent of thanks, grasped his hand and wrung it fervently.

We heard all about the episode in camp that night. Later we examined the carcass of the slain bear and speculated on whose trap it was from which he had so nearly escaped. We refought the fight all over again a dozen times, comparing and criticising the versions of the three envied participants.

Horace's courageous part in the affair did not lack spirited and enthusiastic chroniclers in Conway and Wallace. He became a hero over night, and from this moment could be dated Wetherby's complete rehabilitation in the eyes of the camp. We remembered now that since "the renaissance," as we dubbed the altered attitude first observed in him after that night alone in the forest, Horace had been a different person. Indeed, this encounter with the bear was not entirely responsible for our change of heart toward him. But it needed some such conclusive evidence of nerve to finally crystallise the camp's changing opinion of the once despised axeman. He proved himself by this exploit, as Conway put it, a "regular fellow."

We moved to Diamond Creek on Thursday morning, the first of September. For a night or so before leaving we had missed old man Reed. We could not understand why he had so abruptly ceased his evening visits. I wondered if perhaps it might not be in some way. connected with his partner, Jake. 
Our trail ran by his ranch and some of us were for stopping on the way and bidding him "adios."

But Brown threw cold water on the suggestion.

"Better not bother with the old man," he cautioned. "Ef he didn't come over the last few nights he must-a-had his reasons. He takes streaks that-a-way."

It was as well that we decided to abide by Brown's advice. As we neared the ranch we heard at regular intervals the sound of shooting-two shots at a time. We wondered what it might portend.

As we came within sight of the weather-beaten $\log$ cabin the mystery was solved. The Hermit sat alone in a particularly dignified attitude on his front steps, puffing slowly on his corn-cob pipe and gazing straight before him. Every once in so often he laid down his pipe, raised a huge demijohn to his lips, and drank long and lovingly. Then he carefully set down the demijohn in its turn, and, emitting several ear-splitting whoops, picked up a shotgun and emptied both barrels into the innocent empyrean. The pipe and the dignified mien were thereupon resumed, until a recurrent impulse impelled a repetition of the performance we had witnessed.

As we passed out of sight he was just coming into action for the fifth time. And the last I recall of the Hermit is the sound of his unleashed voice in my ears, the sight of his white-haired, gaunt person posed erectly on his threshold, eyes aflame and shotgun thrust menacingly toward the zenith. 
"Is that one of the old man's streaks?" I inquired of Brown.

"He's drunk!" replied the latter, indifferently, as if that was sufficient explanation of any and all phenomena, however strange and unexpected. And, when you come to think of it, I suppose it is. 


\section{CHAPTER XXIV}

\section{ON DIAMOND CREEK}

For several days the weather had been cloudy and unsettled. But on the morning when we woke in our first Diamond Creek camp a complete overnight change had occurred.

It was crisp, cool and clear-a true fall day-one of those heartening, out-of-doors, woodsey mornings when the dew on the grass sparkles mischievously, when the sun strikes the earth with a warm caress that quickens the electric air, when the sharp, sweet song of birds keeps time to the mounting song in the blood of the just-awakened camper.

As the first soft spring evening of the year sometimes will linger in the mind, noteworthy by contrast with its forgotten fellows, so this September day though no different, perhaps, from those that followed, still stands unique for me, still has its own niche in the galleries of recollection.

From this time on to the end the weather was perfect. They were halcyon days these, cloudless, and with the crystal clearness of atmosphere and the tonic snap and sparkle of frost that autumn in the mountains means. The damp, sweet balsam odour of the firs, the cheery, crackling fires of pitch164 


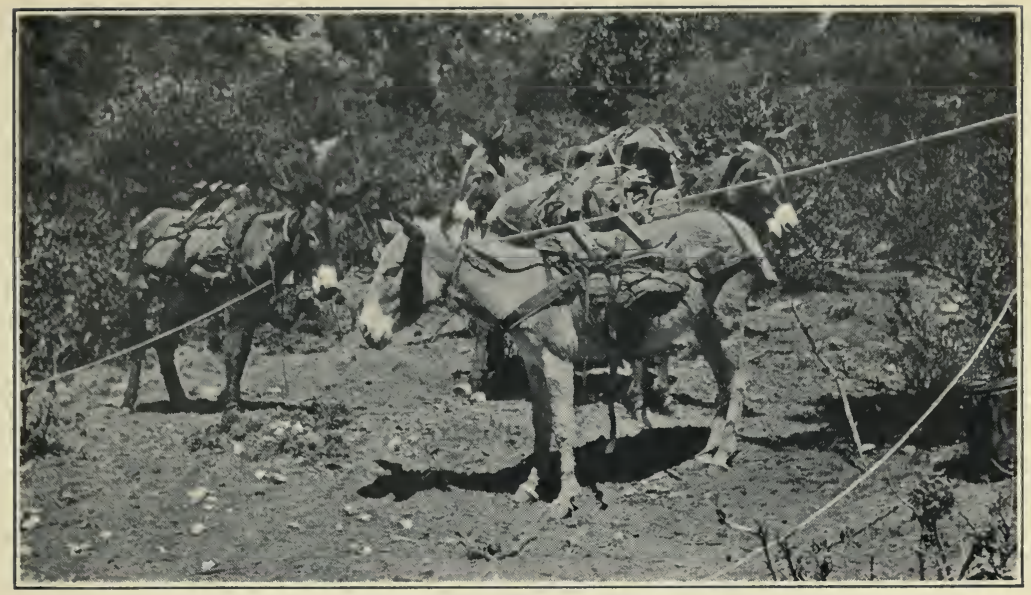

\section{MOVING DAY}

Packsaddles were cinched on the burros and they were tied to a tree or shrub until their turn came to be packed

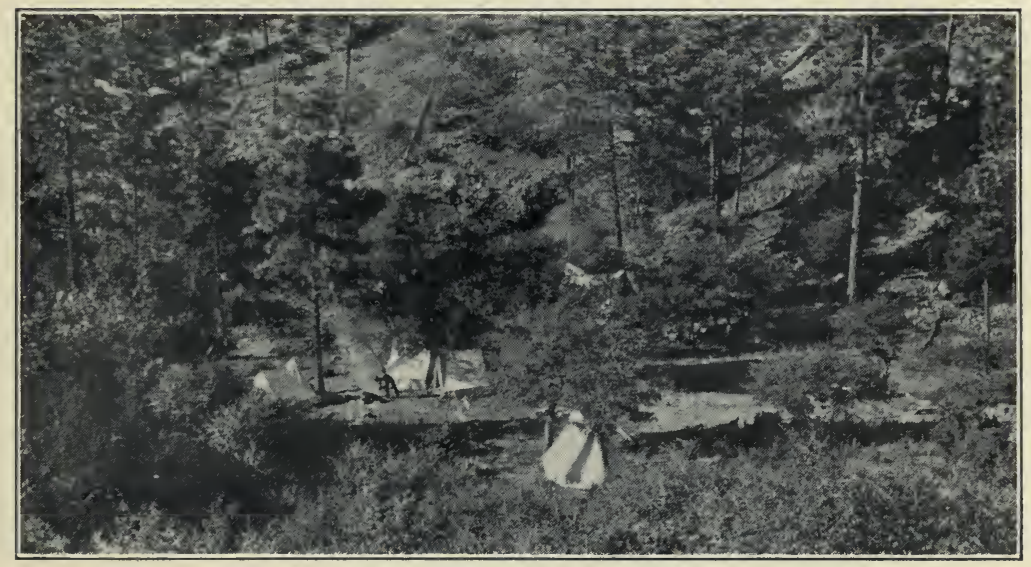

FIRST CAMP ON DIAMOND CREEK

A typical camp in an open stand of yellow pine 

pine round which we gathered with tingling fingers and glowing faces, the yellow and crimson leaves, dropping one by one, the little searching wind that came and whispered secrets of the northern caves from which it sprang-everything seemed new, and fresh, and wonderful.

Yet there was too, when I think of it, a shade of something like sadness through it all, a vague, uneasy longing for similar days long past gone to return no more, a something dimly reminiscent in our emotions, in the smell of burning wood, in the sense of shortening days, in flaming sunsets or the sharp, clarion call of a cold dawn. There came over one a melancholy at times, that strange nostalgia of the spirit which for want of clear cause we assign always to something concrete and tangible that we have known or loved.

My thoughts were wont at this time to wander forlornly to scenes wherein turkey and mince pie were prominent, where chestnuts and popcorn and great, cheery, open fires and smiling, kindly faces appeared-scenes and faces once seen so often in other times, and now so very well, so very clearly remembered after the intervening flurry of years!

Our runs in the Diamond Creek country were ideal. An initial climb of six or seven hundred feet from the base line in the canyon-a climb to rouse the heart and warm one's blood-and we found ourselves on wide, level, flower-studded mesas, beautiful in the bright sunshine as plains of asphodel. 
Here was the coveted Diamond Bar range. Cattle, fat and sleek, cropped leisurely at the lush grama grass. Cows, with wide-eyed, awkward calves, long horned, inquisitive steers, lowering, self-sufficient, massive bulls. We ran through them every day, and whereas on the east side we had found the cattle small and lean, wild as deer and scarcer, here they seemed to mind our presence not at all. Mostly they merely raised their heads and glanced indifferently at us as we passed, or if in our line lumbered slowly off as we came up, to turn at a little distance and gaze with mild curiosity at the rare phenomenon of a man on foot.

On these mesa runs, in scenes so strange to us, so different from the barren east side or the heavily timbered top of the range, a curious feeling of unreality came over one at times. It was as if field and flower, the blue, brilliant sky, and the wild life about, were one and all mere creations of our subjectivity, with no distinct identity of their own,mere strokes and shades in a masterpiece made solely for our peculiar pleasure.

Out in the morning, then lunch, then home again, miles over the level, flower-studded mesa. That was our daily schedule. Only, perhaps, on our return run we would encounter, instead of cattle, a herd of white tail deer. Sometimes they heard our careless approach and we caught merely a glimpse of flashing bodies ascending some distant slope with incredible leaps. Or we might come upon them un- 
awares, in a shady grove or thicket, when often we were able to approach to within fifty paces or less before alarm was taken.

Once as I was sighting the compass an eightpronged buck, followed by six does, jogged past. They were headed for water, on a cattle trail not a hundred feet away. They seemed in the last stages of exhaustion, heads down, shoulders sagging forward, ears drooping forlornly, for all the world like a row of tired hounds.

At a whistle the seven deer whirled toward me and stood erect, motionless as if frozen. Then suddenly what a scattering and springing! What a clatter of stones and a darting of tawny forms through the startled air! What a sudden and complete vanishment of those same weary looking animals I had so pitied a moment before.

Probably one of the chief reasons, if not the chief, for our enjoyment of our work at this time was the excellent physical condition in which we found ourselves. The week's rest on top, following our exertions on the east side, had given us a chance to recuperate. This, with the bracing change of air and temperature, the sound sleep and the good food since, had made us thoroughly fit, overflowing with strength and spirits. The daily cruise was child's play for us now. Our legs were like steel springs, our wind perfect. We seemed never to tire, never to exhaust the reservoir of energy.

Day after day we fairly romped through forty, 
section and township. Three camps were made on Diamond Creek, five miles apart. Then over the divide we went to Black Canyon, next on the south, and up that to the head. For we had to tie on to the work at the top, near Reed's place, which we had left so shortly before.

Black Canyon was considerably larger than Diamond Creek. Also, the fishing was better. Speckled trout in hundreds leaped through its shallow ripples or lurked in the depths of its overhung pools.

Bert and Bob Moak were our star fishermen. They were always at it. Bert was accused of inventing a method of automatic dish washing so that he might be free to dash off up or down stream directly after meals. And Bob one day made a sixmile run in five hours in order to fish till supper time. We always held that he must have slid down a five-hundred-foot bluff to the river to accomplish the feat.

While the rest of us were content to do our fishing on Sundays, we did not hesitate to help dispose of the trout when they were caught. And so plentiful were they that we had a mess practically every morning and evening while camped in the canyon. That this consideration added materially to our list of daily blessings need not be stated-at least, to one who has been some time greeted on his return from a long hike with the appetizing sight of fish 


\section{ON DIAMOND CREEK}

frying in the pan, or who has waked in a cold, invigorating dawn with the delicate odour of hissing, sputtering trout in his nostrils. 


\section{CHAPTER XXV}

\section{LOST MAN'S PARK}

Near this camp on Diamond Creek lay the famous Lost Man's Park, a little open, tree girdled hollow, wherein, marked by a surmounting pile of stones and a rude wooden cross, rest the bones of the wanderer from whose misfortune the spot derives its name.

The dead man's story is unknown as would, indeed, but for an accident, have been the fact of his death. Some years ago two cowpunchers on the trail of a maverick literally stumbled over the bleaching skeleton of this unfortunate. He appeared to have been seated, leaning against a great fir tree, when the end came. No clue was found to his identity, nothing to indicate the manner of his death. Only an old gun, a Rip Van Winkle relic that fell to pieces when touched, and a hunting knife, bone handled, lay on the ground nearby. That was all.

But in spite of-or perhaps because of-this paucity of material, legends sprang up about the Lost Man, as legends will, and grew and were repeated with constantly accumulating details until they came, in one form or another, to be believed by every one.

Perhaps the most popular version recited how the stranger, coming from afar, some said in search of gold, others of an enemy whom he had sworn to 
slay, entered the mountains one blustering fall with inadequate supplies, and a little later, lost and ill, seated himself at the foot of the huge tree which forms now his titanic tombstone and there died, his purpose unfulfilled and his heart bitter within him. This, averred the more imaginative, was the reason why the spirit of the Lost Man stole forth still sometimes in the dead of night and pursued once more through the dark corridors of the forest the unfinished quest of days gone by.

The park was a pleasant place by daylight, under the golden sun. A court of waving grasses and wild flowers of many colours, a bower of sweet odours and bright hues, a rare spot to lie and dream, in the hours when work was over, gazing lazily upward at the blue circle of sky with its dark border of softly stirring tree tops. The tiny glade had a charm. We spent all our leisure moments there. And our words and thoughts were ever of life-as was natural-and of living things, with never, or rarely, a glance or a passing mention for that menacing hint of mortality, the stony grave close by.

It was otherwise at night. A few of us strolled over after supper on the evening of the day we made camp. We sat on a little rise overlooking the park and built a fire for warmth, though the night was more than ordinarily mild. But the firelight in our eyes blew out the soft winking stars and I moved away before long, a little distance from the flames, the better to enjoy the scene. 
The stars were glorious, clear and diamond bright. The sky seemed truly alive. It quivered and glowed with an intense, coruscant energy. How could any one ever feel lonely, I wondered, with such an infinitude of sparkling, vibrant bodies all about, all parts and partakers of the same great life, all dwelling, forever and ever, in the same universe that holds our tiny, insignificant selves.

As darkness grew deeper we could see little or nothing of the park below us, only at times a faint glimmer of light showed the position of the Lost Man's grave. A little later the moon rose, slow and serene, swimming sensuously in the low hung mists. And as she rose faint outlines of light trembled in the even blackness of the forest round about. And like a face forming, feature by feature, from the folds of a velvet curtain, there shone more clearly each moment the glade of glistening grass, tree ringed on every side, and plain and plainer we saw the dim cairn of stones, the wooden cross at its foot, and the great fir, the wanderer's tombstone, at its head.

Then in the mystical half light a spell was woven. Objects took on strange shapes, became wavering grotesques, fanciful and unfamiliar. The tall bearded grass was gone. Instead there shimmered a shaking field of silver spears, like the weapons of the Sons of the Dragon's Teeth bursting magically from the earth. And on every side, hemming them in, awaiting fearfully their onslaught, loomed in the 

shadows a horde of monsters born from the impassive trees by the enchantment of the hour.

Only the mound of stones with the wooden cross at its foot remained, dim and deathlike, but unchanged. And the great fir at its head, the wanderer's tombstone, stood as of old in massive dignity, maintaining an age-long vigil over the poor bones entrusted to its care.

The ancient tree stood still and grave and silent, but it was a silence pregnant with deep things. It held the wisdom of the centuries in its brooding immobility; it hinted, somehow, of old, primordial mysteries, locked deep in its slumbrous heart.

But, hush-look! What is that? Something, pale and dim, but something, nevertheless, detaches itself from the great fir and creeps slowly along the grave. It straightens and stands swayingly at the foot of the cairn of stones. It faces us, ghostlike arms outstretched in the form of a cross. It advances, step by gliding step.

$\mathrm{My}$ hair stirred from the roots, a rippling shudder ran along my spine. My mouth was dry. I wanted to yell, but could not. For the moment I was dumb, palsied, petrified! And still, step by sliding step, the shining spectre neared.

A hoarse cry from behind me broke the spell. The others by the fire, which now had burned nearly. out, perceived the apparition.

I glanced around. They were staring, wild-eyed, white faces gleaming in the faint light from the dy- 


\section{THE LOG OF A TIMBER CRUISER}

ing embers, toward the figure that still approached with its horrible, rhythmic glide.

Frazer leapt suddenly to his feet. His revolver glinted as he threw it into line.

"Stop, or I'll shoot!" he cried, loudly. Through his voice ran an odd quaver.

But the figure in white glided slowly nearer.

I heard a crashing of branches and the thud of feet on soft ground. Frazer was alone by the fire, the others gone. Hesitating no longer, he fired three quick shots in the general direction of the phantom.

A yell came from the sheeted figure, hitherto as silent as death.

"What'n hell are y' doin'?" it ejaculated violently. 'Tryin' to shoot a feller up jest fer makin' a little fun?"

The relief was sudden and nerve-destroying. I broke into a hysterical laugh and rolled over on the ground. Frazer, with a face of thunder, threw down his weapon and ran toward the ghost. I had never seen him so thoroughly incensed before.

"You damned idiot!" he roared. "I didn't know you were quite such a _ fool! I ought to fire you right now! Are you plumb crazy or what?"

Brown pulled the tent flap from his head. He endeavoured to assume an air of injured dignity with a somewhat ludicrous result.

"Don't see what y' want to make such a fuss over," he grumbled. "I was jest a playin' ghost. 
Why, doggone it," he finished, angrily recalling Frazer's target practice, "y' might-a kilt me!"

Frazer turned abruptly and walked away. And though the others of us often referred thereafter to the ghost of Lost Man's Park, I have never since that evening heard a word on the subject from the chief. 


\section{CHAPTER XXVI}

\section{AT THE DIAMOND BAR}

ON Black Canyon, half way up, we camped near the home ranch of the Diamond Bar Cattle Company. The owner was a wealthy easterner whom ill health had driven to this charming exile where he now spent the better part of each year from choice.

True to the traditions of the cattlemen, he kept open house for wayfarers. So we were not surprised upon our arrival to receive a dinner invitation. We accepted with pleasure-and not till then did we learn from one of the cow-punchers that a party of six Silver City girls, campers en route to the top of the range, were also to attend. This was rather perturbing. We had for so long been guiltless of participating in anything remotely approaching a social function that we were nervous. Our available wardrobes, too, were hardly calculated to lend distinction to the affair.

However, there was nothing to do but fix ourselves as fetchingly as possible and go.

Frazer, the camp barber, trimmed each untidy shock of hair into a semblance of neatness. Beards and moustaches in various styles were removed. There was a great spattering of water, a prolonged 
scrubbing of faces and hands, a searching and researching through dufflebags and beds in the feeble hope that somewhere might be found a garment or so which we had neglected to wear entirely threadbare.

At last we were dressed as well as our resources permitted. Bob Moak and Frazer led the procession out of camp, being voted the most effectively attired. Bob sported two large green patches in the seat of his overalls, and Frazer had unearthed a faded red cravat, the only bit of neckwear in the crowd if one excepts Brown's spotted cotton handkerchief. We others following were remarkable rather for our unwonted flow of high spirits than for any decorative qualities we possessed.

The party, notwithstanding, was a huge success. Once in the house we forgot ourselves and our clothes completely. Previous misgivings, the fear that for lack of practice we should not know how to behave in the presence of women, vanished instantly. We enjoyed every minute of the evening. It was really an astonishing treat for us.

The girls appeared to our sharpened senses beautiful as sirens and witty and charming beyond description. There was an indescribable zest to everything. Never had lights shone so brightly nor music sounded so sweet nor lace and ribbons and dainty faces and silver laughter seemed so marvellously satisfactory, so altogether delectable.

And the dinner! 
I think I have stated somewhere that Bert was a noted cook and Frazer was unusually generous in his commissary. Whenever it was possible the packers had killed a beef on the range, settling afterward with the owner, and had kept us as a rule well supplied with fresh meat. As camp fare goes we lived unusually well.

But to-night-it was a different thing altogether. As we tasted the strong, well seasoned soup; demolished heaping platters of fresh vegetables and fruits, revelled in fried chicken and cranberry sauce and sweet potatoes and salad, we thought for the sake of contrast of our beans, canned goods and bacon and shuddered deliciously.

After the feast we talked and sang and played delightful, foolish games, till the big, rough-ceiled, log-walled hall echoed with shouts that shook the roof and even the merry stars seemed to look down in wide eyed astonishment at the tremendous clamour.

It was a wonderful night, a magic night!

And-believe it or not-the life of the gathering, the feature of features, was-Horace! He certainly made a hit! The upright, broad shouldered figure, the tanned features, the worn, stained clothes that he wore, appealed at once by their picturesqueness. He was before long the centre of a circle of admiring femininity and handling his admirers like a general.

Since his regeneration, Horace had gladdened our 
hearts by a growing tractability, earnestness, and modesty. No vainglorious matter now passed his lips. Nor did he, as formerly, attempt upon every possible occasion to rectify the frequent and lamentable errors of his companions. He talked less and performed to better purpose. He seemed anxious to be judged by his actions rather than by his words.

But it soon became evident this evening that our comrade was fast losing his hard won self-control. The flattering attention of the girls began to exert its inevitable effect.

Horace struggled for a time. He set his jaw hard, casting nervous glances at the rest of us, and manfully resisted the temptation to expand, till a particularly pretty girl looked ravishingly up into his eyes and pleaded:

"Oh, Mr. Wetherby, do tell us something of your trip. You boys must have had such stunning adventures!'”

And Horace fell. Nay! rather he leapt to destruction-succumbed gloriously and spectacularly! $\mathrm{He}$ threw himself into the pleasant task of painting for his fair auditors our life as it was not, but should be, with entire abandon. His language was marvellous! There was a veritable conflagration of rhetoric fanned by a whirlwind of wonderful ideas. Never was heard so impetuous a stream of dramatic narrative, never were there such word pictures as our prodigy painted, and never, needless to say, were statements singly and collectively further from 
facts than those so successfully offered by him that night.

Upon his canvas we saw the woods transfigured, the life we lived idealised, ravishing in its care free joyousness. We recognised our own faces, drawn one by one, or grouped chorus-like, a background for the heroic image of Horace himself, which stalked, debonair and calmly efficient, through the stirring scenes depicted.

There is no question about it, Horace was good! The utter unleashing of his imagination made him convincing. That was his power, he lived his words. Even we who knew him fell under his spell, in a way, half believing for a moment in the truth of the absurdities we heard, half accepting as facts what reason branded indubitably as fiction.

At the same time we wondered rather sheepishly at the phenomenon, and were somewhat ill at ease. Here was our erstwhile incompetent emerging from the chrysalis of his mediocrity and taking with scarcely an effort the centre of the stage. We others were for the time being mere lay figures in his drama, subordinated to the moment, and feeling, if the truth must out, supremely unimportant and insignificant. Indeed, as the situation developed, it seemed rather incredible that we should have ever ventured to criticise this prince of romancers, to judge and condemn by our narrow views and straitened standards so evident a genius.

Even after it was all over, the last song sung, the 


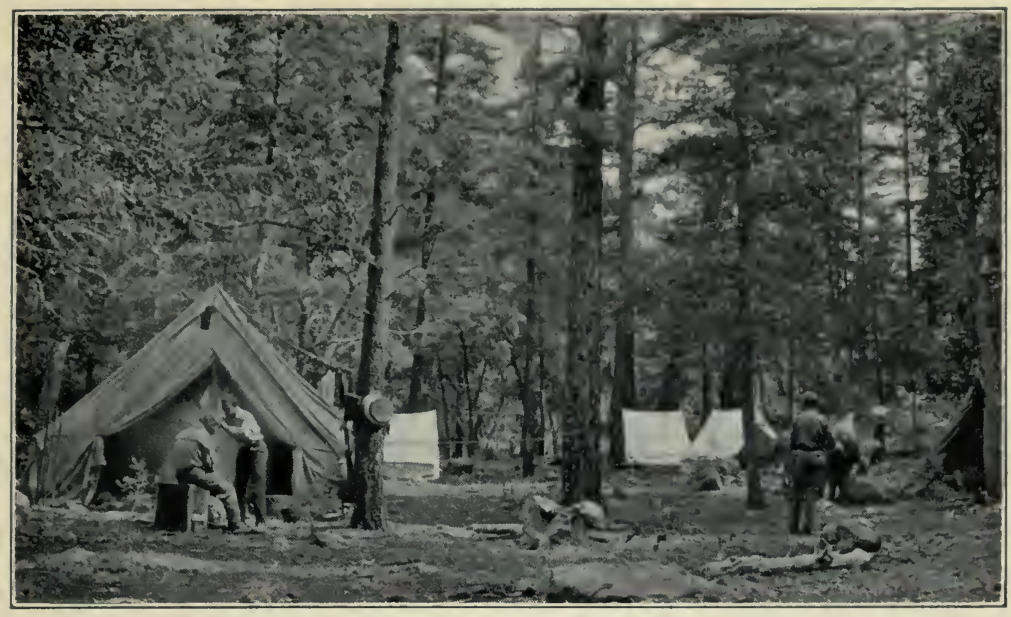

\section{PREPARING FOR THE PARTY}

Frazer acted as barber for the rest of the outfit

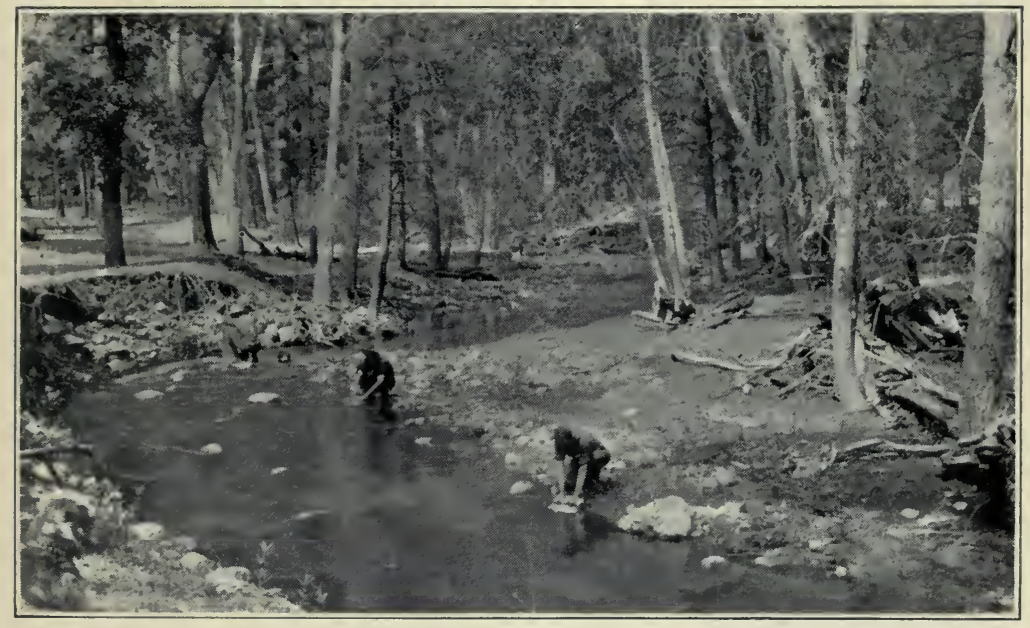

WASHING DAY

Sunday mornings were devoted to a general cleaning up 

last "good night" said, as we walked campward up the creek, we could not quite adjust ourselves to the situation. We looked curiously, now and again, at Horace. He strode along vigorously, proudly, head in air, rapt and still intoxicated by the luxury of self expression and the incense of unstinted admiration.

Each one of us was silent, busy with his own thoughts. Horace's mood remained undesecrated, his triumph and his happiness complete, without a flaw.

The next day, Sunday, Horace was still under the spell of the events of the preceding night. His elation had not perceptibly ebbed. He was in far better conceit with himself than we had been used to seeing him of late. We wondered whether it might not become necessary to tone him down a little before he could be trusted to work to advantage. But as it happened, fate spared us that task.

Most of us had washing to do, that morning, so we walked down the creek about a half mile to where we might precede the laundry work by a swim. The water was ice-cold and no one stayed in very long. Horace, a good swimmer, was the last to acknowledge its chilling effect. He even ventured on some mild "horsing," as one by one we others, blue lipped and shaking, sought the bank and hastily donned our clothes.

We were nearly dressed and Horace, for our delectation, was demonstrating the "crawl" in about 
two feet of water, when the first of six horses, walking single file, turned the bend a scant forty feet below us and advanced leisurely up the trail. Upon the horses, riding astride, were the six girls from Silver City, the late guests of the Diamond Bar. Snapping twigs and the soft "thud, thud" of hoofs first drew our attention to the approaching cavalcade.

One glance was enough for us! We glided, silent as wraiths, into the timber. At the same moment Horace, emerging from the water, beheld the invasion.

"Back!" he cried hoarsely, his anguish manifest in an unnatural intonation.

\section{"Back! Don't you see I'm here?"}

Nobody ever knew what possessed the unhappy youth to propound that particular query. It was superfluous, to say the least. Probably for that reason it remained unanswered and obtrusive-as if suspended in the chilly air.

Looking neither to the right nor to the left the fair campers passed sedately by with no sign of recognising Horace's existence. Only, as they rode slowly out of sight, the pretty girl whom Horace had especially favoured crushed a handkerchief to her face and I could swear I saw her shoulders shake convulsively.

Poor Wetherby, after his first awful outburst, relapsed into a complete and desperate silence. By a timely contortion he had lowered himself in the shal- 
low stream so that only his head and neck were above water. And from the chattering of his teeth and the bluish cast that crept over his countenance we surmised that his enforced submergence was anything but pleasant.

It is safe to say, however, that the discomfort of body was nothing to the agony of mind that our squire of dames endured. The ignominy he felt, following so closely upon last night's triumph, was bitter. Indeed, so evident was Horace's distress that we forbore to dwell upon the incident at any. great length. We felt-and as time proved, rightly - that we would have no further fault to find with Horace on the score of arrogance or militant selfesteem! 


\section{CHAPTER XXVII}

\section{HANK HOTCHKISS}

IN two more camps we had accounted for everything along Black River. There now remained only the block of country between us and the North Fork of the Mimbres and a strip beyond extending to the tier of sections worked north from McKnight.

The continental divide, by the way, runs through here between the watersheds of the Mimbres and the Gila, into which Black River flows. The Mimbres drains to the east on the Atlantic slope of the divide, and though the stream vanishes completely in the desert near Deming its indicated course is toward the Gulf of Mexico. The Gila drains the Pacific slope of this portion of the range, and eventually, through a junction with the Colorado, its waters find their devious way into the Gulf of California.

The country between Black Canyon and the North Fork was too great to cover by end to end runs from each canyon, the method we had been working on, so we camped on the divide for a time at a deserted ranch called the Meson Place, where there was an excellent spring.

From this location we were able to work the more inaccessible parts of our unfinished block before 
dropping to the bed of the North Fork for the final spurt. We were visited here by Supervisor Johns from Silver City, and Pooler, an Assistant District Forester from Albuquerque, on a tour of inspection. Randolph, the ranger from Fierro, accompanied them and stayed with us until we went in, but the others only stopped over night.

At "Meson's" we ran across Hank Hotchkiss, a former soldier and scout now well-known locally as hunter and trapper.

When we visited his camp for the first time we found the old woodsman engaged in the novel pastime of teasing a huge Mexican eagle that had just been caught, oddly enough, in one of his smaller traps. The bird was tied to a tree with a rope about five yards long, which gave it a chance to exercise after a fashion.

We asked the trapper if he intended to tame his pet, and he laughed.

"It can't be did, not to my knowledge, leastways," he stated. 'I kep' one once for five years an' he'd fight me just as quick when I let him go as when I caught him. They's queer critters, that's a fact. Did you ever cut one of 'em up? No? Well, they got an eye nigh as big as the rest of their head put together, an' as for brains, they hain't got more'n enough to fill a 22 cartridge. I don't believe they got sense for anything but to fight. That's all they is to them!"

He tapped the captive eagle on the head as he 
spoke, and the bird, glaring angrily, struck at him with its sharp beak and seized the edge of his shoe in its great talon with such strength that the claw sank through the leather and could with difficulty be dislodged.

"Looky there now," said Hank; "he almost got me that time. Jest like he took a-holt of Spot, my hound, the other day."

We begged for details.

" 'Twas pretty cute," chuckled Hank. "Hennery - th' eagle-was eatin' on a rabbit I throwed him, 'an' he seen Spot was a watchin' him kind-a close. So he jest walked away a few steps an' pertended he was through with th' meat. Spot hops in an' begin eatin' an' Hennery he give a jump an' lit plumb on the middle of Spot's back. I thought the dawg was a goin' $t$ ' turn hisself inside out a' tryin' to git him off. When Hennery finally come loose he took along a piece of meat about so big right out of Spot's back. Since then they hain't been th' best of friends, but Spot allus gives way to th' bird."

Besides the eagle, Hank had caught during the summer three mountain lions, a lobo wolf, two brown bears a black bear and a huge silvertip grizzly. He showed us the pelts, which were in poor condition and worth but little. The animals had been either in the process of shedding or their hair, just coming in, was short and of inferior quality.

The trapper would have fared ill from a financial 
standpoint were it not for the bounty which cattlemen offered, usually from ten to twenty dollars for an adult lion, wolf or bear, which are all great cattle destroyers.

"I've shore had hard luck," he complained, "I'd orter had oodles of skunks, foxes an' bob cats in my little traps, but by gum, I been a catchin' my dawgs in 'em more'n anathin' else. That there ormery Spot would travel twenty miles to git into a trap. Every time I go out I find him a howlin' in one of 'em sum'mers!

"The other night he went out huntin' an' never showed up in the mornin'. I knowed right away what had happened. Soon's I got to my first traps, down on Squaw Canyon, thar was Spot, caught by the foot and howlin' reel mournful. I took him out an' beat him t'well I was plumb wore out, an' he went off toward th' house lickitysplit. An' by gum, afore I made the round of my traps I found the pore fool caught in another trap. I give it up after that. If that there's his idee of pleasure I figger tain't goin' to do no good to try an' break him of it. Hit remines me of th' time I caught an Injun. D'ye ever hear tell o' that? No! Well, I never seen him myself, but I hearn tell of it afterwards. He shore got in th' trap an' I was plumb pleased he got away 'fore I found him, becuz I could tell by th' way he'd tore things aroun' there he'd a-been mighty hard t' turn loose."

Continuing the score of his misfortunes, Hotch- 
kiss averred that two bears had just lately pulled loose from his big Number 4 trap by the rather shocking expedient of twisting the prisoned foot off. Some of us were inclined to doubt the truth of this tale, but before we moved camp we had ocular proof of its verity.

A trapper, if he can, visits his traps each morning. The chances a captured "varmint" has of escaping are thereby greatly lessened. But Hotchkiss worked alone and found it impossible to make the round every day. So it happened that when he started on a tour of inspection the following Sunday it was for the first time in two or three days.

He returned about two in the afternoon very much worked up, and exhibited a gruesome trophy. It was a gigantic bear's foot, torn off at the ankle.

"Looky there," he shouted, "whad-die tell you all. I didn't git around to my Number 4 yestiddy nor day before, an' I done missed th' biggest grizzly you ever see. Here's what he left in the trap for me, as a soovenoor!"

"Couldn't you track him?" we asked, after inspecting the "souvenir" with considerable disrelish. "Naw," replied Hank, "I tried to, but 'twarn't no use. I see where he dug ground up all around the trap twissin' his foot off, an' where he slid down the side of the canyon after gitten' away. But where he done run off down th' creek I couldn't find no sign nowhar. He'll likely hole up some'rs till 
he gits healed, or light out and leave the country right now."

But as subsequent events proved the wounded bear chose neither of these alternatives. Frazer, crossing Little Rocky next day, some distance below the trap, heard the loud complaint of a grizzly issuing from a small clump of brush, and, cautiously investigating, discovered Hank's missing bear. The animal was almost helpless from loss of blood and it was no trick at all to put him out of his misery with the Lüger automatic that the chief carried.

To his great astonishment Frazer found upon examination that the animal was minus not one foot, but two; the wound on the fore leg a recent injury, the dry scar on the stump of the hind leg indicating an older hurt.

Hank looked the carcass over carefully when we went out to skin it.

"By gum," he declared, "I've caught this here bear twice. Last year I got a hindfoot jist the size of this here one in one of my traps, an' I'm satisfied this is the critter left it there. Yes, sir, he's done tore off two feet in them traps and now we got him after all. Ain't that the outbeatinest thing $y^{\prime}$ ever heerd tell on?"

Frazer later bought the two missing feet from the trapper, who had kept them safe, and sent the hide in to be mounted. It never made a very valuable piece of fur, but the chief would not take several times its actual worth for the rug. 


\section{CHAPTER XXVIII}

\section{THE LAST CAMP}

ON the sixth of October we pitched our first camp in the North Fork. By the night of the fifteenth we had covered our season's assignment. The Black Range was cruised and mapped. The summer, with its pleasures, and its hardships, was over, and we were free to hike for town.

The last day of cruising was, by a coincidence, the opening day of the game season. Some of us were anxious to try our luck on a whitetail buck, so for this reason, and also because the trip in to Silver promised to be an arduous one, Frazer decided to stay over until the seventeenth. Those who would might rest, the others could hunt.

Wallace, Conway, Wetherby, Jackson, and myself spent the holiday looking for deer, but with the exception of the ranger we might just as well have stayed in camp. Jackson left with his 25.20 carbine directly after breakfast and reappeared about nine o'clock with a fair sized buck slung over his shoulder. He and Brown skinned and dressed the deer and for supper we had venison steak, the first I had ever tasted. The meat was exceedingly tough, due mainly, no doubt, to the fact that it was cooked so soon after the death of the animal. As a matter of 
fact, though, most of the natives, who can get both, prefer good beef to venison any time.

We had a visitor that night. It was just dusk, and Bert was putting the finishing touches on the steak. We were startled on a sudden by a shrill falsetto yell. It sounded like a woman in distress. We listened breathless for a moment and the sound was repeated, near at hand. Then out of the woods along the trail there trotted a raw-boned white horse with a very small rider in sombrero and leather chaps, leading a pack mule by a tie rope. He wavedi to us as he approached and Brown rose to his feet with an exclamation of surprise.

"I'll be doggoned ef hit ain't that there crazy kid. brother of mine," he said; "what in thunder d'you reckon he's a-doin', comin' out yere!"

The boy alighted somewhat stiffly, and proceeded to answer the question himself.

"I done brought you all some veg'tables," were the first words he spoke, nodding to the pack on the mule. "Lef' Hillsboro this mawnin' at sun-up an' bin ridin' ever sence."

"Chuck's ready!" yelled Bert, at this juncture; "come an' git it 'fore I throw it out!"

Comment and inquiry were postponed for the time being. We discovered later that little Johnny Brown, who was just nine years old, had travelled forty miles that day alone over the rough mountain trails on the chance of striking our camp. His father had allowed him to take the trip as a birth- 
day gift. He wanted to go into Silver with us and see the town, an ambition which, I'm glad to say, was subsequently realised.

That evening we sat around the camp fire for the last time. Mostly we sang and talked as usual, but now and again a sudden silence would fall upon us all, or a look of wistful gravity drop for a moment like a veil over the features of one or another of the men. One can not leave six months of his life -full, vivid months like these-without a poignant twinge of regret. The hardships we had undergone, the companions with whom we had lived and worked for half a year and whom we had learned to care for and to trust, could not lightly be put behind us.

We would soon be scattered, most of us never to meet again. The age-old ache of sadness at the death of the familiar, at the ruthless approach of change, the wrench of readjustment in leaving the accustomed thing and making shift to face the unknown future gave us many a sober thought. Beneath the excitement of the impending release was a vague desire for continued captivity. We weakly longed at times to keep on living as we had grown used to living, enveloped by the web of accustomed circumstances which we had at once yielded to and conquered.

In one of these pauses Frazer began to talk.

"I want to tell you fellows," he said simply, "before we part, how much I appreciate personally your attitude during the past season. I've worked on re- 


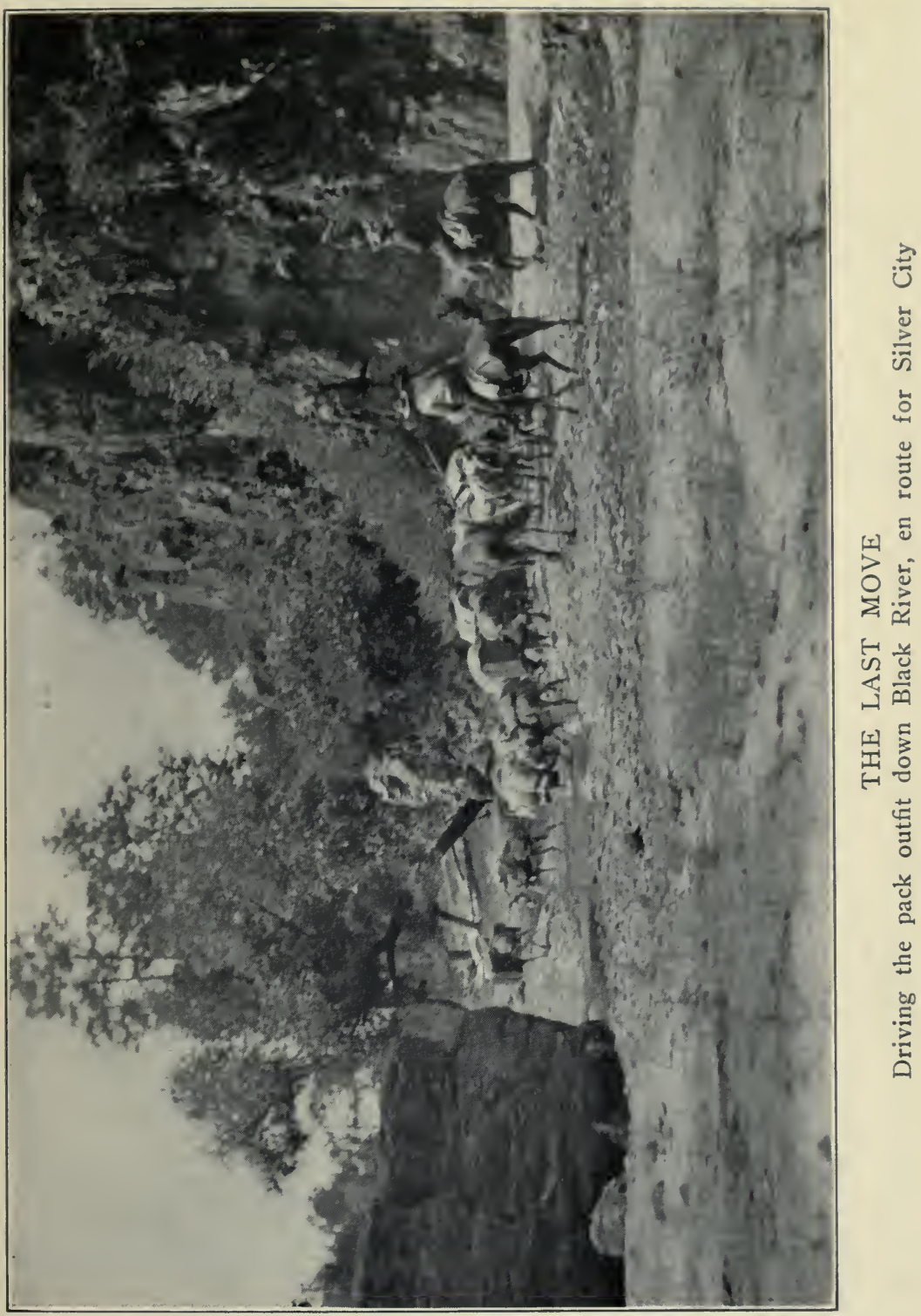



connaissance since the Forest Service came into existence and before, and I've never known a more difficult job than we have just completed nor met a better spirit than you've put into your work. We've run nearly a hundred and fifty miles of baseline, cruised more than two hundred and fifty thousand acres of timber and woodland and made thirty-two camps, and all in the roughest and most constantly difficult cruising country I've ever come across. Primarily we are working for a living. But in a sense we've gained something even more important by this season's experience. We have been developed and changed by our daily tasks, and the habit of doing them, in spite of all obstacles, honestly. We have broadened our point of view by the associations made here in the woods and through a better understanding of one another. We are different men from those who started out in May. I want you to know that I feel deeply the value of it all to myself and that I am certain that though we separate now to the four winds the results of our summer's experience will remain with each of us through life."

We were rather surprised by this speech. Frazer was essentially undemonstrative, and we knew that he felt all and more than he had said. And his talk gave us a sort of lonesome, empty feeling. When he spoke of parting, it was as if some friend had died. Never again, we thought, would there be such days for any of us. Yet we knew that we were the better 


\section{THE LOG OF A TIMBER CRUISER}

for them, as the chief had said, and we knew that it was all symbolical-that it was life! There rang in my brain a fragment of crude verse, penned by a former reconnaissance man, that met the mood well:
"You're sorry," you say, "the season's done!"
"Me and you both," I say, replying,
"For now the leaves are yellow and dying;
Summer is dead, winter's begun,
And summer's chance companions parted.
But this is the sure road each man takes;
This is the law that nature makes;
Why should we then be broken-hearted?"

On "get-a-way day" we woke early. Every one was excited and in high spirits, now that the actual move was upon us.

Before we left camp we had a grand bonfire of old clothes and other articles whose usefulness was outworn. Bert rescued a suit of silk pajamas which some one had kept closely hidden during the trip, and draped them upon "Babe," the burro colt, of whom he had made a pet.

"It's the first time he's been to town," explained Bert, "an' he'd oughta be dressed up, jest to show 'em he hain't ignorant of what's wore in the fast set nowadays."

Babe's reluctance to don evening clothes was overcome with difficulty but, once attired, he trotted: proudly to the head of the pack train and kept his suit on until he reached the corral in Silver City. 
We got under way about nine-thirty and did not stop walking for a minute, not even for lunch, till night found us but twenty miles from Silver and forty miles from our "place of beginning," as surveyors say.

We were quite ready to make camp. Our trail had been down hill all morning, to where the North Fork joined the main stream of the Mimbres, and over this fifteen-mile stretch the packers sent the burros along at a trot. We were obliged to do between four and five miles an hour to keep up, and considering the character of the trail and the weight of our cruising shoes this was by no means a despicable feat. Toward noon the canyon broadened and the fertile valley of the Mimbres, with its ranches and fruit farms, lay unrolled before us.

Round we swung to the south, into a broad, level highway, the famous North Star road, built by the War Department in early days, and now most grateful to our tired feet. Down the river by this pleasant winding way we travelled for ten miles and more. The pace was not now so swift. The loaded burros were beginning to feel the effects of earlier efforts as well as we, and to slacken speed accordingly.

At last we crossed the Mimbres and entered Shingle Canyon, heading in a northwesterly direction. Up this incline we toiled, mile after uphill mile, till darkness compelled us to halt. We made 


\section{THE LOG OF A TIMBER CRUISER}

camp by throwing down our beds beside the road. After a snack of bread and butter and hot coffee we were glad to crawl into our blankets and forget our weariness in sudden sleep.

Though we were just about played out that night it spoke well for our condition that there was hardly a limp or a stiffened muscle in camp next morning. The remaining twenty miles between us and Silver City, all on a fair road, we disposed of easily enough.

At just one o'clock we entered town and swept down Main Street-bells ringing, packers halloing, and Babe in his gay attire stepping out in front like a tiny drum major. It was a gay cavalcade, if ever one existed. No wonder our entry created a stir in town, that we were followed to the Tenderfoot corral, our destination, by the plaudits of the multitude and a swarm of small boys who, after the manner of their kind, sprang suddenly and miraculously from nowhere! 


\section{CHAPTER XXIX}

\section{FINIS}

WHILE the burros were being unpacked and unsaddled we went over to the office to report our return, in case Supervisor Johns had not heard the excitement caused by our entry.

As we entered the Supervisor's sanctum we saw a huge man of about fifty years, dressed rather formally and imposing to a degree, seated comfortably in the largest chair in the room.

He smiled cordially as we entered.

"Gentlemen," said Johns, impressively, "permit me to introduce Mr. Wetherby."

We gasped, as Horace, with an astonished cry of "Father!" sprang forward and received the parental embrace.

The gentleman turned toward us. His mien was suave and dignified. He reminded us strongly of Horace at his best. But in his eyes there shone that which revealed the difference between them-a look of conscious power, of hard-won wisdom. Where the boy gazed out on life naïvely, and coloured it with his own imaginings and thoughts, the shrewd, objective glance of the older man penetrated to the essence. 
"I chanced to be in this part of the world yesterday," he said, in a deep and resonant voice, "and hearing that you boys would be coming in from the wilds I just thought I'd run down and meet you all.'

He paused, and that keen, searching eye swept us, one after the other. It was like a suction cleaner applied to the soul.

He smiled, and went on: "I need not say that I am more than happy to meet my boy's friends. And to have at the same time an opportunity of talking over some matters in regard to the Forest Service with your Supervisor-Mr. Johns, here. I hope to detain him some time longer on the same business. Afterward, I want you all to join me in a small supper that has been planned for this evening at Lin Foo's, which I am informed is more generally known as 'The Chink's.' What do you say?"

We accepted, of course. Then we scattered, to bathe and dress. Some of us, too, had promised ourselves the luxury of a call or so before dinner time.

At about five-thirty I cut short a wonderfully brief visit and started for the restaurant where Mr. Wetherby's affair was to take place. As I turned the corner of Bullard and Main I ran full into Horace and the pretty girl of the Diamond Bar adventure.

They were walking quite close together, talking cosily and confidentially. My sudden appearance 
did not embarrass them in the least, though I felt somewhat vaguely that it should.

"Why, how do you do?" exclaimed the girl, cordially. "Off to the banquet, I suppose?"

"Yes! Wetherby's told you the news, of course. About his father, I mean."

"Bless you, I knew all about it yesterday! Mr. Wetherby dined with us-he and Father are old friends-and we planned the feast for you boys as a sort of 'welcome home.'

"Afterward you're all to come up to our house. Some of the girls are coming over and we'll try and amuse you for awhile, if you aren't too tired out for such frivolity."

I expressed my individual pleasure at this arrangement and continued on my way to the Chink's, feeling a little as if I had stepped off the back platform of a swiftly moving train. What a busy little town Silver was!

We enjoyed the dinner immensely, with the possible exception of Bert. The uncompromising cook plainly appeared to suspect the genuineness of the hospitality of any father of Horace's. His sense of propriety triumphed, however, over his uneasiness, and the affair passed off in all respects pleasantly and harmoniously.

With the coffee and cigars our host rose.

"I want to say a few words," he began, "before you all leave for the dance which I understand is planned in your honour. 
"Your able Supervisor," here he bowed graciously. to Johns, who seemed in rare good humour, "has been giving me much valuable material regarding your forests in general, and the Gila National Forest in particular. And in consequence I have, I think I may say, a much more comprehensive grasp of the subject than I had before our conference."

Here the speaker paused, while we all cheered.

He bowed and went on:

"I have learned much about the Gila, but nothing" which could be termed derogatory. It was with pleasure, therefore, that I gathered from my son to-day that he intends taking the examination of Assistant Forest Ranger next week, which test, I understand, some of you young gentlemen are also to attempt.

"I speak of this now, among Horace's good friends, because in the past, I have, like all fathers, at times felt some misgivings in regard to his choice of a career. And I realise that to the association with you boys, his companions in camp and cabinto you and to his friends in Silver City-is due this sudden resolve on his part, a resolve I have only sympathy for, a resolve that will cause him, I trust, to bear his part worthily in a world of men."

The speaker was visibly moved. His words held the unmistakable ring of genuine feeling. We felt a little uncomfortable, and, I'm afraid, a little sorry for him. Horace a ranger! Did he have it in him to make good? It was hard to say. But then we 

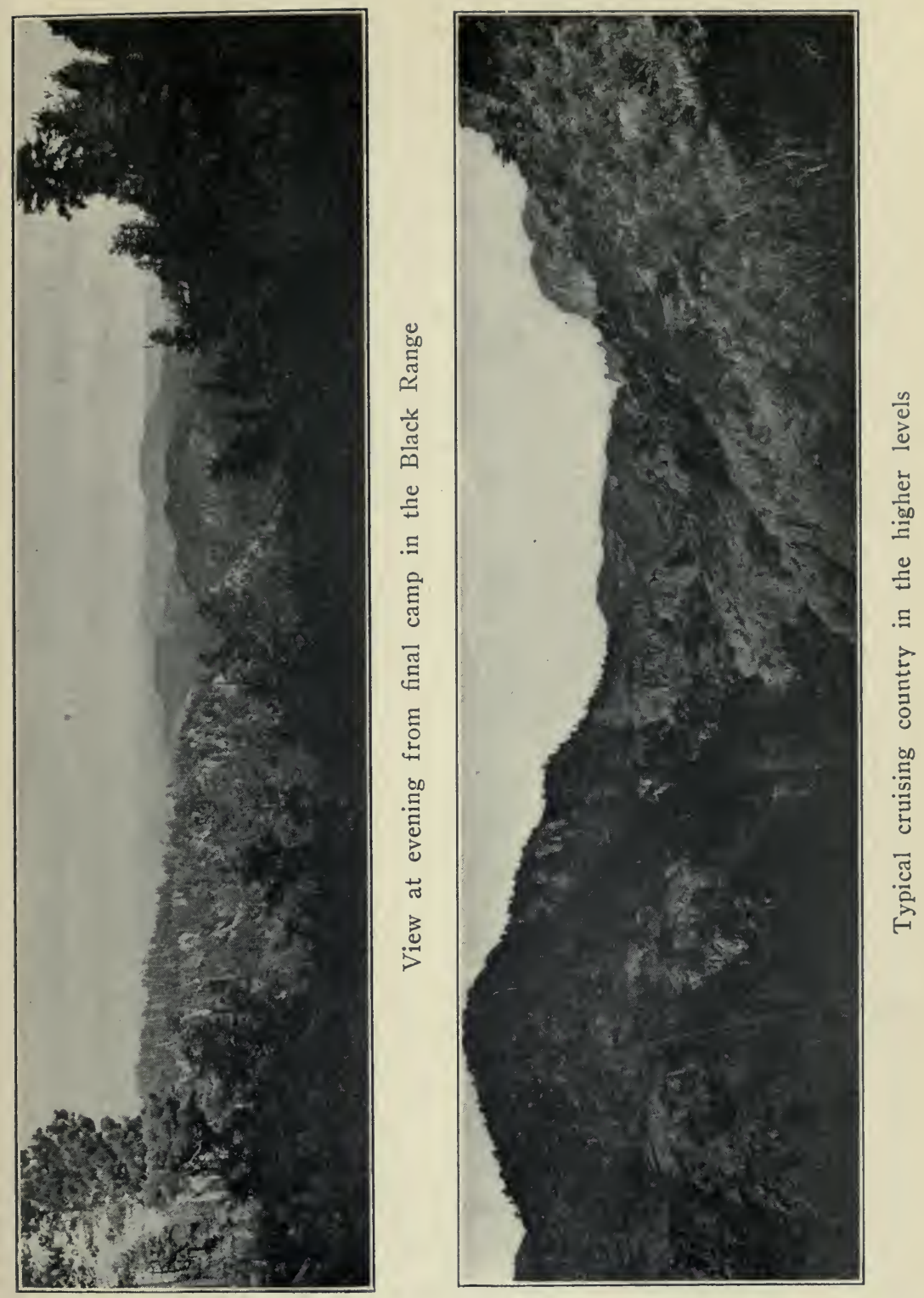

remembered his sudden change of heart, in midseason, and his subsequent vast improvement and, most encouraging of all, the nerve and determination he had shown. In the silent, bronzed youth who sat with us to-night and the young man who had so jauntily descended from the train six months before, there was a world of difference. Perhaps, after all ...

Something of this line of thought seemed to be in his father's mind as well as in ours.

"I know reconnaissance is trying work," he said; "Horace's letters home bear internal evidence of the hardships you have been through. But I think it has helped him, as it doubtless helped all of you, to a better understanding of a man's duties and privileges.

"Before closing, I want to read to you some verses which my son sent home during the latter part of your trip, and which I understand he has not shown to any of you. I think they deserve a hearing and a judgment at your hands."

He smiled - alone in his emotion. So Wetherby had burst into poetry, without our knowledge! We prepared to suffer as the Senator cleared his throat and began to read:

"They call our work 'Reconnaissance';

A shorter, uglier word, perchance,

Would better serve the new man's use

To circulate his heartfelt views, 
When first he strikes the higher hills And suffers 'pedatory' chills!

"At first each separate 'forty' seems

A mile across! Each 'corner' gleams

A beacon in a world of night;

The tyro thinks: 'This run's a fright,

I'll never see the camp again-

My kingdom for an aeroplane!'

"His legs are stiff; his feet are sore,

He carries bruises by the score;

Each day's a crisis in his life,

An aeon of unending strife

And even as at night he dreams,

The cook, with breakfast ready, screams.

" He grumbles at the 'rotten chuck,'

And figures that he's out of luck,

Nurses a grouch exceeding glum

And wishes that he'd never come;

Like Job, his last despairing cry,

'I'll curse the Government, and die!'

"But as the season wears along,

He finds he's growing hard and strong,

The steepest peaks with glee attacks,

And gaily, skilfully he tracks

The elusive contour to its death

Nor pauses once to gasp for breath!

" $\mathrm{His}$ attitude is altered quite,

The work's a cinch, the world is bright,

He has a glance for towering trees,

For rocks and streams; the mountain breeze 
To him is musical, he'd fain

A-cruising all his days remain!

"And when he's ordered back to town

And on a district settled down,

He'll think: 'This ranger job's all right,

You get to sleep in sheets at night;

But I'd sure like another chance

At working on reconnaissance!' ",

It wasn't so bad as we had expected. As we clapped and shouted our approval our host raised his glass and said:

"I want to propose a toast, and, if you will forgive me, I will ask Horace to respond to it. Gentlemen: The Forest Service!"

There was a dead silence.

"Where is Horace?" asked his father, at last, frowning. "I don't see him!"

Bert, from the foot of the table, answered.

"When you begin talkin' about him that-a-way," he drawled, "an' readin' that there pome, he gits red in the face an' makes a quick sneak. Tole me to tell you, if you asked, that he had to tel'phone a gal about some dance favours or sumthin'."

The frown faded from the magnate's face. He smiled slowly, broadly, winked one eye shrewdly, and bending forward over the table whispered confidentially to the assembly:

"I hereby amend that toast! To the Forest Service and its feminine well-wishers-present sweet- 


\section{THE LOG OF A TIMBER CRUISER}

hearts and prospective wives-individually and collectively: Here's luck!"'

Mr. Wetherby's ready estimate and acceptance of the situation made the hit of the evening.

And as we laughed and cheered and touched glasses and sipped the Chink's wine, we felt the toast no empty form but a true symbol of our thoughts and feelings. We saw the Service and its loyal friends in that moment not as an abstract idea or a romantic ideal, a thing to make pretty speeches over, but as a living, working, hoping, striving body filled with a single spirit, as a whole of human beings composed like ourselves of good and of evil; as thousands of companions, known and unknown, scattered throughout the land, north and south, east and west, whether officers or in the ranks, whether young or old, whether in district or in camp or in the midst of towns and great cities or like ourselves "a-working on Reconnaissance!" 


\section{AN INFORMAL GLOSSARY}

Adios

Spanish for "good-bye." Used commonly in the Southwest. About the same as "Well, so long!" in New York.

\section{Alidade}

Webster calls it "the portion of a graduated instrument, as a quadrant or astrolabe, carrying the sights or telescope, and showing the degrees cut off on the arc of the instrument." Perhaps the description given in the text may prove as enlightening as this definition to the layman.

\section{Aneroid Barometer}

"A barometer the action of which depends on the varying pressure of the atmosphere upon the elastic top of a metallic box (shaped like a watch) from which the air has been exhausted. An index shows the variation of pressure."-Webster. This watch-shaped box, instead of hours, had numbers marked on its face-from one to twelve thousand, by thousands, - and spaces between to indicate each hundred feet in the thousand. It had one hand, which we commonly set by screwing the top of the case around, at the elevation our stations recorded when starting to cruise. As we went up or down thereafter this hand was supposed to record the difference in altitude, computed on the variation of atmospheric pressure, by moving around to the proper space on the face of the instrument. I say "supposed to" "because sometimes it didn't work with the exactness of a chronometer. I would like to record my impres- 
sions of aneroids in general, and the one I carried in particular, but space forbids-as does also the fear that patient readers who have worked their way this far might leave their perusal with an unpleasant impression.

\section{Annual Rings}

When a tree trunk is sawed through, if you examine the flat top of the stump you will see, starting with a very small ring at the centre, a series of concentric rings of varying width, some very small, some larger, extending to the outer bark. By counting these rings one can determine the age of the tree, since each one represents a year's growth in the life of the tree. The smaller rings (in width) indicate that the year was a dry one and only a thin layer was added to the trunk during the season. The wider rings indicate that the year in which they grew was a favourable one and that the tree thrived.

Baile Blaze

Spanish for "dance." Pronounced "bi-ley."

If there is any one who is unfamiliar with this common woodsman's and surveyor's term they should learn at once that it is a spot made on a tree trunk by slicing off a piece of bark. Blazes are usually employed to mark the course of a road, trail, or line through the woods. A "witness" blaze, often with data cut on its face with a "scribe," a little tool with a blade like a. curved chisel, is usually put on one or more trees called witness trees near any section corner or other monument to indicate its position and what it stands for.

Bronc or Broncho

An unbroken animal. Usually a young animal not past the ordinary age for breaking. When a horse or 
burro has lived wild till long past this age, which may be from two to four or five, or has escaped to the range after being broken and lived for a time in a wild state, he is called an "outlaw."

Bueno

Pronounced in New Mexico "way-no." Spanish for "good."

\section{Burro}

The Mexican substitute for the flat car, the moving van, wagon or wheelbarrow. A beast of many burdens. The best known test for self-control in the Southwest. To give all the definitions of this little beast that one might gather in the course of a day's ride through the country where it is found would be against public policy, so we will refer the reader to the text of the story for further information on the subject.

\section{Calipers}

An instrument consisting of a straight rule set off in inches and fractions thereof, with two arms attached to it at right angles, one fixed at the end of the rule, the other sliding along the rule. One of them is placed on either side of the trunk of the tree, whose diameter is thus shown on the rule. To "caliper" a tree is to measure its diameter by means of the calipers. When this diameter is found at the height of four and a half feet from the ground, called "breast height," and the height of the whole tree is estimated, the number of feet of timber board measure that the tree will total when cut and made into lumber can be learned from volume tables prepared for the purpose.

\section{Cardinal}

The cardinal points of the compass are the four principal ones, East, West, North, and South. 


\section{Chain}

"An instrument consisting of links, used by surveyors in measuring land." - Webster. The chain commonly used is Coulter's chain, which has one hundred links each $792 / 100$ inches in length, making the total length four rods or sixty-six feet. Hence, a measure of that length.

Contour

The line in which a horizontal plane intersects a portion of ground, or the corresponding line in a map or chart.

Cowpuncher

The same thing as a cowboy, which the dictionary says is "one of an adventurous class of herders and drovers on the plains of the Western United States." Only for some reason no puncher will answer to the epithet "cowboy," while if you called him a herder or drover he would undoubtedly grow vexed and perhaps "bow up." Cowpuncher is much the most respectable word of the lot. And "punching" cattle, it may be added, is a very reputable and businesslike business nowadays, whatever it may once have been. Also the adventure element-in the sense of romance-is found chiefly between the covers of works of fiction.

\section{Cruiser}

When used to describe a man who estimates the number of board feet in standing timber on a given area, it means the members of our reconnaissance partyexcepting the packers and the base line crew. In the dictionary a colloquial meaning is given-6"to cruise is to wander hither and thither on land." That suggests our work by antithesis, because we did exactly the opposite, travelling always in a straight line by the compass and only wandering, when we had the time to wander at all, mildly and in our minds. 
Dufflebag

A bag of heavy canvas, cylindrical in shape and varying in size (fourteen inches in diameter and three feet long being about the average dimensions), open at one end, with a draw string to close it by. The dufflebag is used extensively by campers and woodsmen to carry clothes and light personal effects. A substitute for a trunk or traveller's handbag or suitcase. Its advantage lies chiefly in the fact that it may be packed more easily and weighs less than those articles.

F'loat Rock

A term used by miners and prospectors to describe fragments of ore found on the surface of the ground away from the vein outcrop.

Forty

A section, or square mile of land, contains six hundred and forty acres, which in surveying and map work is divided into sixteen squares of forty acres each, called "forties" for short. A sixteenth part of a section. Each side of a forty measures twenty chains, or thirteen hundred and twenty feet.

Forest Assistant

An officer of the Forest Service who has studied technical forestry, passed the Civil Service examination for the position and received an appointment in the Service under that designation. While the Forest Assistant is theoretically supposed to chiefly plan with and advise the Supervisor on matters involving silvicultural problems or forest management, in actual practice he generally undergoes a thorough apprenticeship in administrative work, timber cruising, and the various branches of Forest Service field duty.

Forest Guard.

The position of Forest Guard is purely appointive, usually for a period of three months. The appoint- 
ment may be renewed by the Supervisor at his discretion. The duties of a guard are practically the same as those of a Ranger, the chief distinction between the two positions lying in the precedence of the latter by virtue of its superior grade in the Civil Service lists.

\section{Forest Ranger}

The administrative field mau of the Forest Service. Each National Forest is administered from headquarters by a Forest Supervisor. Under him are several rangers, each living on a Ranger District in quarters provided by the Forest Service and responsible for the conduct of Forest Service business in his territory. But the Ranger like the Forest Assistant is liable to assignment for a time to some special project-such as Reconnaissance, for example.

\section{Forest Supervisor}

The man in charge of a National Forest, and responsible for its proper administration to the District Forester.

Gila

Pronounced "Hee-la," the Spanish G having the sound of $\mathrm{H}$. The name of a river in New Mexico, and of the National Forest, covering over a million acres, whose headquarters are at Silver City. It includes the Black Range within its boundaries.

Jack. Jinny

The male and female, respectively, of the Burro species. Jacob's Staff

A name which has been since the middle ages given to many forms of staff or weapon, especially a pilgrim's staff. In surveying, the Jacob's Staff is a round, straight rod something like a broom handle, about four feet long, pointed and iron-shod at the bottom and having a socket joint at the top. When 
stuck in the ground it is used instead of a tripod for supporting a compass. This is the sense in which the Kyacks

term is used in the story.

Boxes or canvas bags slung in pairs on a horse or burro, one on each side, fastened to the horns of the packsaddle by leather loops, and used, as are panniers, to pack articles more conveniently than could be done otherwise.

\section{Lick}

Local name for syrup or molasses.

Malpais

The rough surface of a congealed lava stream. Volcanic rock, extremely hard and bad for the feet. This rusty or dark coloured stuff, that looks like twisted old iron and feels like-nothing else, covers a good part of the surface of the ground on the plains and mesas of the southwest.

Mesa

From the Spanish word for "table." A high tableland or plateau, usually with steep sides. A formation found everywhere in the Southwest.

National Frorest

One of one hundred and sixty-three areas set aside to be administered under the United States Forest Service for the permanent benefit of the people. Offset

In surveying, a short distance measured at right angles from a line actually run to some point or some object. Protractor

A mathematical instrument, circular or semi-circular in form, with the angles marked off upon it, so that the angle of any direction may be found by sighting along a movable arm that may be turned at will about the circle. 


\section{Range Branding}

Cattle on the Western ranges run practically wild and are seldom caught or coralled except for branding or when sold. One of the chief duties of the cowpuncher is to ride about the range and catch every calf which he sees unbranded. He then burns in the proper brand which may be ascertained by examining the cow with which the calf runs. This is called Range Branding, because the work is carried out on the range without waiting for the general roundup.

\section{Reconnaissance}

Preliminary examination or survey. In Forestry it includes the mapping of the country worked, an estimate of the timber by species, and descriptive data indicating the watershed system and logging possibilities of the territory covered.

Reproduction

The general term, in Forestry, for the young growth in a forest, including seedlings, saplings, and polesthe names for the tree at various stages of early development. Upon the character and quality of the reproduction depends, as far as can be foreseen, the nature of the future forest.

\section{Section}

In surveying, one of the portions-of a square mile each-into which the public lands of the United States are divided. One thirty-sixth part of a township. These sections are divided into quarter sections of one hundred and sixty acres each, which may be preempted under the homestead laws both on and outside of National Forests.

Silvics or Silviculture

The study of trees and tree species, with their growth, peculiarities and habitat, as parts of a forest. 
Slumgullion

A kind of soupy stew or stewy soup, containing meat, vegetables, and the juices of same. Just what the ingredients consist of is beyond the knowledge of the writer. I think it must be a secret.

\section{Stand}

A stand of timber means the trees standing on a given area, collectively.

Sweater

An interested onlooker at a poker game, who usually gets himself included in the orders for drinks, thereby maintaining the requisite degree of enthusiasm. Tarp

A sheet of heavy canvas some eight feet wide and fourteen or sixteen feet long, used as a cover and outside spread for the blankets which make up the camp bed. Tin-Horn

A gambler whose appearance or protestations of recklessness are out of all proportion to his ability to redeem them by actions. In the world of betting the phrase holds somewhat the same significance as does the "five dollar millionaire" of the Great White Way. A cheap sport. A four-flusher.

Township

In surveys of the public lands of the United States, a division of territory six miles square, containing thirtysix sections.

Varmint

A wild or vicious animal which should be avoided or slain. Opposed to "critter," which signifies a harmless or domesticated animal as the cow or the house cat. A burro may fall in either category according to circumstances.

Volume Tables

Formulæ for determining at a glance the number of 
feet board measure a tree whose diameter and height is known will yield when it is felled in logs of various lengths.

Wrangling

In camp horses or burros are usually loosed at night and the business of looking them up and bringing them in in the morning is called wrangling. 







